\title{
Acheulean variability in Western Europe: The case of Menez-Dregan I (Plouhinec, Finistère, France)
}

\author{
Anne-Lyse Ravonn a, ${ }^{\mathrm{a}}$, Paula García-Medrano ${ }^{\mathrm{b}, \mathrm{c}, \mathrm{d}, \mathrm{e}}$, Marie-Hélène Moncel ${ }^{\mathrm{b}}$, Nick Ashton ${ }^{\mathrm{c}}$
}

a Université de Rennes, CNRS, Ministère de la Culture et de la Communication, CReAAH-UMR 6566, 35042 Rennes cedex, France

b Department of Prehistory, CNRS-UMR 7194, National Museum of Natural History, Institut de Paléontologie Humaine, 1 rue René Panhard, 75013 Paris, France

${ }^{\mathrm{C}}$ Department Britain, Europe and Prehistory, British Museum, Frank House, 56 Orsman Road N1 5QJ, London, UK

d Institut Català de Paleoecologia Humana i Evolució Social (IPHES-CERCA), Zona Educacional 4, Campus Sescelades URV (Edifici W3), 43007 Tarragona, Spain

e Universitat Rovira i Virgili, Departament d'Història i Història de l'Art, Avinguda de Catalunya 35, 43002 Tarragona, Spain

\section{*Corresponding author:}

Email address: al.ravon@hotmail.fr (A-L Ravon)

\begin{abstract}
The establishment of the Acheulean in Europe occurred after MIS 17, but it was after the harsh glaciation of MIS 12 and during the long interglacial of MIS 11 that human occupation of western Europe became more sustained, with an increased number of sites. Menez-Dregan I (Brittany, France) is one of the key sites in western Europe that dates from this threshold, with an alternating sequence of 16 occupation levels and four marine deposits, from MIS 12 to 8 . The large lithic assemblages of over 154,000 artifacts from knapping (cores, flakes) and shaping (macro-tools and shaping flakes) show the varying use of raw materials and activities at the site through the sequence. This work focuses on the study of the handaxes and cleavers using technological and metrical methods with multivariate analysis, in combination with geometric morphometrics, and places these analyses within the context of other technological changes at the site. Collectively, results show the persistent use through the sequence of the same lithic raw materials and technologies, including fire-use and the import of glossy sandstone from $20 \mathrm{~km}$ away, but with variation in activities at the site. These findings suggest that Menez-Dregan I shows the development of a specific material culture that reflects the local resources and environment. Results further indicate that the site shows the sustained hominin occupation of the area, despite varying climate and environment, with strong traditions of social learning that were maintained through flexibility of site-use, deep understanding of the local territory and the innovation of new technologies, such as the use of fire. Evidence from the site is placed within the wider context of Europe, and contrasted with areas to the north, such as Britain, where hominin occupation was more sporadic and driven by cyclical climate change.
\end{abstract}

Keywords: Lithic technology; Geometric morphometrics; 3D models; Handaxes; Cleavers

1. Introduction 
The Acheulean in Europe appears sporadically after $900 \mathrm{ka}$, first from evidence of biface manufacture at La Boella in Spain (Vallverdú et al., 2014), followed by several sites in western Europe after 700 ka at La Noira, Caune de l'Arago (P levels) and Moulin Quignon (France), Notarchirico (Italy) and Brandon Fields (UK; Barsky and de Lumley, 2010; Moncel et al., 2013, 2015, 2018a, 2020a; Voinchet et al., 2015; Antoine et al., 2019; Davis et al., 2021). However, the relatively small number of sites suggests low population densities in Europe and occupation of northern latitudes predominantly during periods of temperate climate, with the exception of the site of Moulin Quignon (France), which has been attributed to the colder climate of MIS 16 (Antoine et al., 2019). It has long been recognized that there is a threshold in human occupation from ca. 500 $\mathrm{ka}$, starting in the interglacial of MIS 13, followed by the harsh glaciation of MIS 12 and the long interglacial of MIS 11 (Roebroeks and van Kolfschoten, 1995; Roebroeks, 2001, 2006; Dennell et al. 2011; Ashton and Lewis, 2012; Moncel et al., 2015; Blain et al., 2021; Ashton and Davis, 2021; Moncel et al., 2021). The period sees a marked increase in sites and an expansion into central and eastern Europe, which is argued to reflect a more sustained human presence across the continent. It also corresponds with new technological strategies, including the beginnings of prepared core technology, working of wood and bone, improved hunting technology, and better evidence for the use of fire (Warren, 1911; Thieme, 1997; Roberts and Parfitt, 1999; White and Ashton 2003; Gowlett et al., 2005; Voormolen, 2008; Dennell et al., 2011; Roebroeks and Villa, 2011; Ashton, 2015; Schoch et al., 2015; Moncel et al., 2016a, 2020b; Ravon et al., 2016a, 2016b; Zutovski and Barkai, 2016; Davis and Ashton, 2019; Milks et al., 2019). These innovations also seem to correspond with current genetic data, which show that Neanderthal features emerged in populations between 600 and 400 ka (Hublin and Pääbo, 2005; Hublin, 2009; Bermúdez de Castro et al., 2013; Meyer et al., 2014). Likewise, the period provides the first evidence of the regionalization of traditions in material culture that suggest small-scale, social networks of sites with adaptation to local circumstances, which in some instances appears to see the adoption of prepared core technology (Moncel et al., 2015, 2016a, 2018a, b; 2020b; Ashton et al. 2016; Rodríguez-Hidalgo et al., 2017; Barsky et al., 2019, 2021; Davis and Ashton, 2019; Ashton and Davis, 2021).

Although there is great deal of evidence for the technological improvements during this period, few studies have investigated how and why innovations appeared, developed, were transmitted, and then were maintained among the different populations (Dennell and Roebroeks, 1996; Roebroeks, 2000, 2006; Gamble, 2008; Dennell et al., 2011; Rodriguez et al., 2011; Mosquera et al., 2013; Ashton, 2015; Davis and Ashton, 2019; Moncel et al., 2020c, 2021; Ashton and Davis, 2021; Barsky et al., 2021). The catalysts for these changes have been debated in the literature, and include non-mutually exclusive parameters such as the arrival of new populations from Asia or Africa (Dennell and Roebroeks, 1996; Roebroeks, 2000, 2006; Dennell et al., 2011; Mosquera et al., 2013), widespread improvements in cognition (Gamble, 2008; Ashton, 2015) and/or the internal development of existing traditions within Europe (Rodriguez et al., 2011; Davis and Ashton, 2019; Moncel et al., 2020c, 2021; Ashton and Davis, 2021; Barsky et al., 2021).

Here we contribute to this debate through a study of the bifacial technology at Menez-Dregan Site I (MDI) in Brittany (France), which records semi-continuous human occupation from MIS 12 through MIS 8. As the northernmost Lower Palaeolithic site in Western Europe with a long sequence of occupations in both temperate (interglacial) and colder (periglacial) phases, MDI represents a unique opportunity to observe the behaviours of Eurasian hominins in this key transitional period. Specifically, to address the question of whether there is continuity in technology, or whether there are innovations introduced from outside the region, we examine changes in biface technology through the sequence in relation to other technological changes at the site, and examine land-use patterns in the context of cyclical changes in climate and the resulting proximity of the coastline. We combine new data on the bifaces from the current study with previously published work on the cores, flakes, flake tools (Ravon and Monnier, 2013; Ravon et al., 2016 a, b; Ravon, 2017a, b, 2019; Ravon et al., 2020) and cleavers (Capdevielle and Ravon, 2021). The results are placed within the context of the western European Acheulean and the transition to the Middle Paleolithic, with particular emphasis of their implications for how human groups operated within a small region of Europe during a period of cyclical changes in climate, with contrasts to the more punctuated occupation of sites further north.

\subsection{Menez-Dregan Site I}


The earliest traces of human occupation in north western France can be found on the southern coast of the Armorican peninsula, at Saint-Colomban, Carnac, Morbihan (Monnier and Le Cloirec, 1985) and at the major site of Menez-Dregan I (MDI), Plouhinec, Finistère (Fig. 1), excavated between 1991 and 2021 (Monnier et al., 1994, 1996a, b; Ravon et al., 2020, 2021). Discovered in 1985 , the former cave of MDI with its long diachronic sequence and abundant lithic industry is a key site for studying the European late Middle Pleistocene. The site has yielded globally important traces of hearths that are among the oldest in Europe (465 +/- 65 ka electron spin resonance [ESR] dating for stratigraphic unit [SU] 9a), as well as abundant lithic material with both debitage (systems of flake production) and façonnage (shaping of tools) which, in the upper levels, show the beginnings of the transition from the Lower to the Middle Paleolithic (Ravon and Monnier, 2013; Ravon et al., 2016a; Ravon, 2019). It represents a unique opportunity to observe the behavior of groups of hominins who lived in the region, both during temperate (interglacial) and colder (periglacial) phases. MDI is therefore a key site for understanding the first human settlements in western Europe, representing occupation in the Armorican Massif by pre-Neanderthal and Neanderthal groups. The site provides insight into the behaviors and environments of the first human populations in the area, being one of the western geographical 'dead-ends' of Eurasia.

$<$ Fig. 1>

The site's long archaeological sequence, dated from MIS 13/12 to MIS 8, and the characteristics of its lithic assemblages (in the past named Colombanian; Monnier, 1996), can be viewed as a case study for developments in technology. The presence of large cutting tools (LCTs), such as choppers and chopping tools that were made on large cobbles of local sandstone and microgranite, is persistent throughout the sequence. This raises the question of the role of the site's coastal location, with its abundant quantities of cobbles in various types of hard stone, in determining the technological features of the industries. The presence of handaxes and cleavers is intermittent through the sequence, which prompts questions about the beginnings of localized traditions of manufacture and regionalization of populations in MIS 11.

The site is situated on the Pointe du Souc'h, above the modern coast. Formerly a marineeroded cave, the deposits infill a narrow gully in a cliff at $7 \mathrm{~m}$ asl. Gradual collapse of the cave roof has led to preservation of the deposits, with improved protection from the erosive action of the Atlantic Ocean at each marine transgression. Paleoenvironmental data indicate that during the prehistoric occupation of most of the archaeological levels, the sea level was much lower, with a shoreline probably 5 to $10 \mathrm{~km}$ further than the current coast (Lefort et al., 2007, 2016). During these phases of occupation, the deposit stood at the top of a rocky promontory and opened onto a vast landscape, providing a strategic shelter for hominins giving them an ideal position above the plain (Monnier et al., 2016a, b; Ravon, 2019).

The stratigraphy preserved at MDI displays an alternating sequence of marine and littoral formations (pebble layers and dune sands) interbedded with slope deposits (colluvium), with paleosols and levels of human occupation dated between MIS 12 and MIS 8 (Monnier et al., 1994; Laurent et al., 1998; Yokoyama et al., 1998; Mercier et al., 2004; Monnier et al. , 2001, 2016a; Ravon et al., 2016a, b; Ravon, 2017a, 2019; ). Apart SUs 1-3 and 10-11, all the levels attest to a human presence on the site, and are presented from the oldest (bottom) to the most recent (top) as follows (Fig. 2):

\section{$<$ Figure 2>}

Layer 10 is the first geological layer infilling the marine-eroded gully. This Pleistocene pebble layer does not present any trace of human activity, and was likely deposited during a high sea level, prior to MIS 12 (layer 9), filling several fissures and marine pools dug into the surrounding metamorphic gneiss of the cave.

Layer 9 comprises SU 9a, 9b and 9c (Ravon, 2017a). SU 9a was dated by ESR to $465 \pm 65$ ka (Monnier et al., 1994, 2001), which places its contained hearth among the oldest fire places in Europe, probably at the end of MIS 12 or beginning of MIS 11. The estimated sea level at the time of occupation was between ca. -60 and $-40 \mathrm{~m}$, based on global climatic models (Shackleton, 1987; Waelbroeck et al., 2002; Lisiecki and Raymo, 2005; Laforge, 2012; Ravon, 2017b) and geoarchaeological correlations (Ravon et al., 2019, 2020). The paleoenvironmental analysis indicates the presence of both a mesophilic forest and a boreal forest in layer 9 . In total, 4,624 lithic 
artifacts and 549 faunal remains have been recorded in layer 9 since 1991, although the latter are very rare in Brittany because of the natural acidity of soils. A total of 31 bone remains was analyzed in the 1990s (Monnier et al., 1996b:77) attesting to the presence of bovids, equids and rhinoceros in this layer.

Layer 8 (SU 8d, 8c, 8b, 8a) is the second archaeological layer at the site. Only SU 8c and $8 \mathrm{~b}$ seem to attest to one (or more) human occupations. SU 8c, discovered during the 2017 field season, shows similarities with layer 9 , and seems to reflect a first phase of human occupation in this level. SU $8 b$ (inf. and sup.) contains almost all the artifacts for these levels $(5,269 / 5,510)$. No clear hearths were identified during the excavation despite the presence of heated soil and of abundant wood and bone charcoal. The new ESR dating carried out in 2016 on samples taken in 2012 from SU 8a places this occupation between ca. $403 \pm 30 \mathrm{ka}$ and $398 \pm 88 \mathrm{ka}$, during MIS 11 (Gaillard et al., 2016:65).

Layer 7 is the third archaeological layer and has many traces of combustion and hearths associated with it. Like layer 9, the archaeological levels that compose layer 7 are interstratified within colluvial deposits. In the absence of dating, SU 7 has been geochronologically attributed to the beginning of MIS 10, with a sea level probably between -30 and -40 m (Ravon, 2017a; Ravon et al., 2016b, 2019). Bone charcoal was detected by micromorphological analysis (Monnier et al., 1996a:25), indicating the presence of faunal remains in this layer, together with 16,440 lithic artifacts.

SU 6' corresponds to a human occupation on a pebble layer of variable thickness (layer 6). The pebble bed is humic and has evidence of pedogenesis, retaining traces of a paleosol, similar to the current coastal soils above the cliffs. The pebble bed from layer 6 attests to a high sea level corresponding to a climatic optimum. With regard to the stratigraphy of the region, layer 6 is attributed to an interglacial phase with a sea level close to the present day, during isotopic substage 9c, ca. $330 \mathrm{ka}$ ago (Ravon and Laforge, 2019). A circular hearth was discovered at the top of the layer in 2009 (Monnier et al., 2009) with wood and bone charcoal. SU 6' is the second most important human occupation at the site, with 20,717 lithic artifacts.

Layer 5 (SU 5a, 5a', 5b, 5b', 5c, 5c', 5d, 5d', 5e) is the most important layer of the site, and the one that delivered the highest number of artifacts (91,668 pieces). Three hearths were also found within the archaeological levels (SU 5c, base of SU 5e/top of SU 6' and SU 5d). Three ESR dates on the heated sediments of the hearth in SU 5e gave ages of $396 \pm 45 \mathrm{ka}, 369 \pm 47 \mathrm{ka}$ and $377 \pm 52$ ka (Monnier et al., 1994, 2001; Yokoyama et al., 1998). A thermoluminescence (TL) date on heated sediment also in SU 5e gave an age of $145 \pm 75 \mathrm{ka}$ (Mercier et al., 2004). TL dating on burnt flints in SU 5a, 5b', 5c and 5d gave results ranging from $167 \pm 16$ ka to $230 \pm 23$ ka (Mercier et al., 2004), and are in complete disagreement with the ESR dating. However, the TL ages are in reverse stratigraphic order, which probably results from a methodological bias due to the natural high rate of radioactivity recorded in the granitic environment (Yokoyama et al., 1998; Monnier et al., 2001; Mercier et al., 2004). The thick sedimentary complex of layer 5 includes at its base a lenticular dune level, only partially preserved (SU $5 \mathrm{e}-\mathrm{d}$ ). This sand may have been deposited during the second climatic optimum of MIS 9a, around 310-320 ka (Laforge, 2012; Laforge and Monnier, 2011), when the sea level was ca. $-30 \mathrm{~m}$. Currently, the different human occupations of layer 5 are thus correlated with MIS 9a (Ravon and Laforge, 2019). Wood and bone charcoal are present in abundance in all SUs in this layer, and a fragment of molar of an elephantid was identified in the center of the structured hearth of SU 5c (Monnier et al., 1996b:77).

Layer 4 (SU 4a, 4b, and 4c) has two successive human occupations: 4c and 4ab (Ravon, $2017 \mathrm{a}, \mathrm{b}$ ). This last human occupation on the site (SU 4ab) marks the beginning of the transition to the Middle Paleolithic in the region (Ravon and Monnier, 2013; Ravon et al., 2016a). No hearth was found in these layers, despite the presence of burnt or thermally fractured artifacts and abundant charcoal. TL dating was undertaken on heated flints in SU 4c, giving an age of $223 \pm 23$ ka (Mercier et al., 2004). However, as currently interpreted, layer 4 is placed in MIS 8 based on the stratigraphical succession, sedimentological analyses and available dating of the overlying and underlying levels (Monnier et al., 2001; Laforge and Monnier, 2011; Ravon and Laforge, 2019). SU $4 \mathrm{c}$ consists of 9,632 , and SU 4 ab of 5,224 lithic artifacts. 
SU $3 b$, on top of layer 4, is an archaeologically sterile dune sand dated by ESR to $141 \pm 16$ ka (Monnier et al., 2001) and ca. $170 \mathrm{ka}$ according to ESR dating in 2016 (Gaillard et al., 2016:65), thus placing this sequence in MIS 6. However, its chronostratigraphic attribution would tend to place it in MIS 7 (Laforge, 2012; Laforge and Monnier, 2011, Ravon and Laforge, 2019). The sequence is finally sealed by a head deposit (SU $2 b$ ), collapsed blocks from the roof cave (SU 2a), another head deposit (SU 1), and the current topsoil (SU 0). When the deposit was discovered, it was coated by a bank of vegetation, obliquely eroding the upper archaeological levels. The excavated upper layers are thus only partially preserved, which explains, for example, the absence of hearths in some of the levels where there are burnt artifacts or charcoal.

\section{Materials and methods}

\subsection{Materials}

The lithic assemblages show a high petrographic diversity due to the complex geology of the Armorican Massif (Ballèvre et al., 2013). However, the assemblages can be sorted into six main types: flint coming from a sub-merged Cretaceous outcrop (40 km from MDI in the Audierne bay), quartz, sandstone, microgranite and quartzite of various types, and glossy (Eocene) sandstone, which outcrops $20 \mathrm{~km}$ inland from the site (Ravon et al., 2016a). Apart from the glossy sandstone, all of the other raw materials are easily found as marine pebbles and cobbles of various sizes and shapes in the present-day or Pleistocene beaches in or surrounding the site.

There is a total of 154,170 artifacts from the 16 occupied levels at the site. Although all of the artifacts have been cataloged, due to the number of artifacts and to the ongoing excavation and post-excavation work, the complete typo-technological analysis of all the material is still in progress. For this study, a representative sample of 1,284 of the 17,684 cores has been analyzed from all levels except SU 8c, which is still in progress. Otherwise, the technological results are based on the entire assemblage, with the exception of a small part of layer 4 and some of layer 9 , since the excavation ended very recently in 2021 . The total number of artifacts from each level is shown in Table 1.

$<$ Table 1>

\subsection{Data collection}

All the lithic artifacts from MDI were sorted and inventoried between 2009 and 2021, under the simplified methodology developed specifically to manage the large quantity of artifacts (Ravon, 2017a, 2019). Every plotted artifact was attributed to a SU according to the observations made on site during fieldwork, in accordance with the stratigraphic succession of the different layers and the evolution of the excavation year by year. The artifacts from all the archaeological layers show excellent surface condition, being neither rolled nor weathered. Each piece was observed and described in detail, including its category (flake, core, fragment, etc.), raw material, surface condition, and general shape (oval, sub-rectangular, etc.). Measurements (in millimeters) and weights (in grams) were also indicated. Each edge and each face were described according to a detailed classical typological grid (after Bordes, 1961; Tixier et al., 1980; Boëda, 1991; Geneste, 1991; Ravon, 2017a).

All the handaxes and cleavers included in this study were also scanned by one of the authors (P.G.-M.) using two scanners: A DLP projector laser scanner (accuracy between 35$50 \mu \mathrm{m}$ ) and Flexscan software v.3.3.5.8. (LMI technologies, Canada) transferred from the Fragmented Heritage Project (University of Bradford), and a Go!Scan3D scanner (accuracy up to 0.0020 inches [in]) with VXElements ${ }^{\mathrm{TM}}$ software (OCreaform Inc., Canada), during two research visits to the University of Rennes 1 (France) in 2018 and 2019. These models are available in PDF format at https://doi.org/10.5281/zenodo.4319919 (García-Medrano, 2020).

\subsection{Methods of analysis}

The core samples from SU 9 to 4ab were studied in detail (Ravon, 2017a). The methodology applied to the MDI core samples is a simplified system to describe the reduction processes apparent on the remaining part of the cores. The flaking of cores is characterized by a series of removals that form a sequence on one or several surfaces of each core (from one and up 
to four surfaces observed on cores in this case). The different scar organizations on each surface are used to interpret these sequences (Table 2). These scar organizations on each flaking surface can be described as follows: longitudinal unipolar when all the removals were made in the same unique direction on the longest surface of the core; longitudinal bipolar when two opposite directions were observed on the longest surface of the core; transversal unipolar when the removals were made in the same unique direction in the shortest surface of the core; transversal bipolar when two opposite directions were observed on the shortest surface of the core; orthogonal when the removals form a right angle from two adjacent directions in longest and shortest surfaces of the cores; centripetal when all the removals converge towards the center of the flaking surface from at least four directions; and on flake when the blank used to produce new flakes is a flake itself. Each core was analyzed and described on every flaking surface and the remaining scar removals were counted, measured and oriented when possible. Three modes of percussion were identified while observing the scars on the cores: flakes were detached using either hard stone percussors (such as quartz, microgranite or some hard sandstones), soft stone percussors (such as soft sandstones or flint cortex) or using bipolar flaking on anvil. This simplified system was chosen to overcome the lack of information about the cores when simply counted by level and by lithological category.

\section{$<$ Table 2>}

To address the question of the variation in bifaces through the sequence and thus of the technological continuity and/or innovations at the site, handaxes and cleavers were analyzed according to the Western European Acheulean Project (WEAP) method (García-Medrano et al., 2020a). This is a unified method of analysis which considers each LCT from two points of view: 1 ) as a single unit, including aspects such as the raw material type, blank type, facial working, cortex presence, edge delineation, profile symmetry, and number of scars; and 2) the sum of three different parts (tip, mid, butt), each analyzed independently, defining the type of hammer used, number of removal series, the depth of scars on the edge, invasiveness of each removal series, and type of shaping (Table 3). Combining all of those features, we applied principal component analysis (PCA) (PAST 3.14 software, Norway) to identify the differences and similarities of LCTs and included biplots to evaluate the weight of each of the variables in our results, depicting both PC scores of samples and variable loadings. The further away the vectors are from a PC origin, the more influence they have on that PC. This PCA was combined with an "average-liked" cluster analysis, where the distance between two clusters is the Euclidean distance between data points in the first cluster and data points in the second one.

\section{$<$ Table 3>}

Using Artifact3_D_febr Software (Grosman et al., 2008), the 3D models were orientated automatically according to their center of mass to avoid subjective manipulation (Fig. 3), and 10 linear measurements, including combinations of length, width and thickness (Fig. 3; Bordes, 1961; Roe, 1964, 1968) as well as two indices, were extracted. Elongation is given as length/width with values $>1.5$ described as elongated. Refinement is measured by width/thickness with refined handaxes having values $>2.35$ (Bordes 1961). We also used the 3D models for geometric morphometric analysis using the AGMT3-D software v. 3.1 (Herzlinger and Grosman, 2018; Herzlinger and Goren-Inbar, 2019). Although the use of 2D images has provided detailed morphometric analysis of tool shape (Costa 2010; lovita and McPherron, 2011; Lycett and von Cramon-Taubadel 2013; McNabb et al., 2018; Hoggard et al., 2019), the use of 3D models represents a step forward (Herzlinger and Goren-Inbar, 2019; García-Medrano et al., 2020a, b; Shipton and White, 2020) by allowing us to combine the analysis of shape with additional measurements, such as volume or thickness of pieces, enabling a wider analysis of all the variables that could contribute to the shape of the tools (García-Medrano et al., 2020b).

AGMT3-D software (Herzlinger and Grosman, 2018; Herzlinger and Goren-Inbar, 2020), uses a deformed grid of $50 \times 50$ homologous landmarks (points) on each of the two faces of each artifact. This consisted of placing 50 equidistant parallel latitudes along the maximal length of each artifact. The length of each latitude reflects the width of the artifact at that specific length interval. Next, 50 equidistant points were placed along each latitude (Herzlinger and Goren-Inbar, 2020). Each point of the grid consists of two semi-landmarks, one placed on each of the artifact's faces, thus providing a web of 5000 landmarks that accurately captures the artifact's volumetric 
configuration (Fig. 3A). The landmark lists of all artifacts were combined into a dataset that was subjected to a generalized Procrustes analysis (GPA) and PCA. GPA was used as a superimposition procedure to remove variability that is unrelated to shape (i.e., variability stemming from differences in scale, location, and orientation in space), enabling the separate analysis of the size and shape of the tools (Herzlinger and Goren-Inbar, 2020; Herzlinger and Grosman, 2018). To interpret the meaning of the PCA results, Procrustes superimposed shape data were examined using thin-plate splines to facilitate visualization of shape changes from the group mean along relative warp (i.e., PC) axes (Hammer and Harper, 2006). By examining the morphological deformations and $X Y$ plots of specimens from the PCA scatters, it was possible to interpret the shape variation independent of size and to compare the different tools within and between sites.

The derived PC scores also permitted us to quantitatively test multivariate equality of means between the groups (e.g., between tool types or raw materials; Costa, 2010; Herzlinger and Grosman, 2018; Herzlinger and Goren-Inbar, 2019). The morphological variability was calculated as the mean multidimensional Euclidean distance between each item in the group and the group centroid (corresponding to the position of the group's mean shape in shape space). This allows the description of specific shape trends as well as the spatial distribution of the variability. In addition, the size of each item in the sample was described using the centroid size index, corresponding to the total 3D Euclidean distance of all landmarks from the item's centroid reflecting its volume. Differences in morphometric indices between various subgroups were tested for statistical significance using the nonparametric Wilcoxon rank sum test, as it does not make any assumptions regarding the distribution of the population. For further details of the 3DGM method see Herzlinger et al. (2017) and Herzlinger and Goren-Inbar (2019, 2020).

\section{$<$ Figure 3>}

In addition, we used the surface analysis $\left(\mathrm{in}^{2}\right)$ and the volume $\left(\mathrm{in}^{3}\right)$ data to quantitatively evaluate reduction intensity. The scar density index (SDI) is the number of flake scars $(>10 \mathrm{~mm}$ in maximum dimension) divided by the surface area (Clarkson, 2013; Shipton et al., 2013; Shipton and Clarkson, 2015a, b). Contrasting this value with volume information, we can show the relationship between number of scars and size of tools. We also used one-way analysis of variance (ANOVA) to test for significant differences among different group means, enabling us to explore if SDI varies according to any other variable, such as the type of blank used for shaping. The alpha level for significance was determined as $p<0.05$.

Lastly, tools not only vary in planshape (zenithal view). There is crucial variation in a tool's profile shape (symmetry) as well. Thus, we also used the landmark data to calculate the degree of deviation from perfect bilateral (Fig. 3B) and bifacial symmetry (Fig. 3C), as well as the edge section regularity (Fig. 3D), of each item in the sample (Herzlinger and Goren-Inbar, 2020). For bilateral symmetry, this was done by measuring the mean 3D Euclidean distance between a mirror reflection of the landmarks placed on one lateral half of each object and the corresponding landmarks on the other half. The same procedure was performed for bifacial symmetry, but on the two opposing faces. In a perfect bilaterally or bifacially symmetrical item, these indices will have the value of 0 , with increasing values indicating less symmetrical items.

\section{Results}

\subsection{Overall technological characteristics through the occupation sequence}

Selection of raw materials is clearly evident and remains constant through the entire sequence. The débitage and small, retouched tools are made from flint or quartz pebbles, or sometimes from glossy sandstone. The façonnage is mainly on sandstone, microgranite or quartzite cobbles. This link between raw materials and tool types persists over time. Glossy sandstone is almost entirely absent in the oldest levels (SU 9, 9a and 8c; Table 4). Although the use of most of the different raw materials appears constant throughout the sequence, the ratio of quartz decreases over time. The only exception to this is SU 4ab, with the lowest proportion of flint at the site, instead favoring sandstone and showing the importance of macro-tools in this level (Ravon et al., 2016a, Ravon, 2017a, b). 
The difference between cores and choppers is clear, as cores are always on small pebbles and are almost exclusively on flint $(81.9 \%)$, quartz $(16.6 \%)$ or glossy sandstone $(0.9 \%)$, whereas macro-tools are distinctively shaped from larger cobbles, predominantly in sandstone $(70.7 \%)$ and microgranite $(23.5 \%)$. The selection of raw materials and the link between raw material selection and tool type is a constant feature of the lithic technology at MDI through time, with flint, quartz and glossy sandstone used specifically for the flakes and small tool production, while larger cobbles of sandstone and microgranite are shaped into macro-tools.

\subsection{Technological developments}

The long sequence of MDI provides a local perspective on technological developments during the late Middle Pleistocene (Table 5; Supplementary Online Material [SOM] Table S1). The sequence is characterized by the persistent presence of fire in all units. Some SUs contain clearly identified hearths (9a, 7, 6', 5e, 5d, 5c), but even where hearths are not evident there is the consistent presence of abundant wood and/or bone charcoal and burnt artifacts that suggests fire use on or nearby the site (8c, 8b, 5e, 5d', 5c', 5b, 5b', 5a, 5a', 4c, 4ab). The presence/absence of fauna is presumably preservational due to the naturally acidic soils in Brittany, although micromorphological analysis revealed the presence of burnt fragments of bones throughout the sequence, other than in layer 4 (Monnier et al., 1996a;23).

$$
<\text { Table 5> }
$$

The distribution of the different artifact types and raw materials throughout the sequence is given in SOM Figures S1 and S2. The distribution of raw materials by main artifact types and the three main types of small retouched tools are given in SOM Figures S3 and S4. While some characteristics of the lithic industries of the site of MDI remain unchanged throughout the sequence, the 16 archaeological levels reflect a somewhat different domestic use of the cave. The main aim of knapping activities through the whole sequence appears to be in situ flake production. The proportion of cores varies from $8 \%$ to $17 \%$. In SU $5 d$ ', the richest human occupation of the site, the proportion of cores reaches $14.3 \%$ (Table 5; SOM Fig. S1). Additionally, the proportion of flakes and flake fragments is nearly always between $70-90 \%$ for each level (close to $90 \%$ in SUs $5 d, 5 c^{\prime}$ and $\left.5 a^{\prime}\right)$, other than SU 4ab, where it drops to $61 \%$. Percussors are present in all layers except SU 5b (Table 1; SOM Table S1; SOM Fig. S1).

Structured cores (e.g., with removal patterns), mainly on small pebbles but sometimes on flakes (SOM Fig. S5), total 17,684 pieces, $11.5 \%$ of the complete series. The sample of 1,284 cores shows that they are mainly on flint (81.9\%), quartz (16.6\%) and glossy sandstone $(0.9 \%)$. Quartzite, microgranite and sandstone cores are rare $(0.6 \%$ of the total cores; Ravon, $2017 \mathrm{a})$. The paucity of sandstone and microgranite cores, and by contrast the abundance of flakes and flake fragments on these rocks, suggest they are by-products of macro-tool manufacture (Ravon, 2017a, 2019). The core categories in all levels indicate that the pebbles were often flaked initially by a hard percussor but sometimes by bipolar flaking on an anvil (Shott, 1999; Donnart et al., 2009; Mourre and Jarry, 2009; Vergès and Ollé, 2011; Lombera Hermida et al., 2016), depending on the SU. Cores were most frequently worked on two surfaces in all levels, but sometimes exploited on one or up to four surfaces, depending on the initial volume of the marine pebble and its natural shape. Scar organization was longitudinal unipolar (LU) or bipolar (LB), orthogonal (OR), transversal unipolar (TU) or bipolar (TB), centripetal (CENT), as shown in Table 2, or even discoidal in the case of SU $4 \mathrm{ab}$, but the latter represents only two cores in the assemblage (Ravon and Monnier, 2013; Ravon, 2017a).

In the older levels, SUs 9a to 9c (MIS 12), there is no sign of handaxe shaping (no bifaces or shaping flakes). Choppers were probably used outside the site after being manufactured in situ as shown by the presence of flakes in sandstone and microgranite, by the absence of cores in these raw materials, and by the relatively high number of small tools (SOM Fig. S6). In SU 5d, the quantity of artifacts is low and there are no handaxes or biface thinning flakes. In SU 5c' handaxes are also absent, but choppers and cleavers are present.

\subsection{Handaxe and cleaver shaping strategies}


Types of raw materials and blanks. The studied LCTs total 58 handaxes and eight cleavers (Fig. 4, Fig. 6), with most on sandstone $(n=35)$ and microgranite $(n=21$; Table 6$)$. For secondary rocks, there are quartzite $(n=6)$, quartz ( 3 tools) and flint (only one tool in layer 5; Fig. 4C). In $84 \%$ of cases, blanks are flakes, with a consistent proportion through the whole sequence. In the lowest levels ( 8 and 7 ), there are three pieces with an indetermined blank as to type due to the intensity of shaping (SOM Tables S2 and S3). Despite the fact that most of the blanks are flakes, and that the lithic assemblages include $0.7 \%$ of large flakes (i.e., where length $>10 \mathrm{~cm}$ ), the cores that produced these blanks are entirely absent from the collection, but possibly appear as cobble fragments or indeterminate material within the inventory of the assemblages (Table 1).

\section{$<$ Table 6>}

In order to analyze the technological similarities and differences between tools, we performed three different PCAs, following the methods of Garcia-Medrano et al. (2020a), each of which included all of the technological features (Table 3). The first PCA distinguishes tools by types of blank (Fig. 5), the second by levels (SOM Fig. S8A) and the third by raw materials (SOM Fig. S8B). There were no $(p>0.05)$ significant differences in shaping strategies at MDI, either through time or in the use of the raw materials. All of the shaping strategies share the central part of the scatter plot.

$$
<\text { Fig.4> }
$$

Nevertheless, the distribution of handaxes and cleavers by type of blank (Fig. 5) indicates a clear technological difference among the tools made on cobbles, on flakes or on indeterminate blanks (SOM Tables S4-S8). These three groups occupy three different areas on the PCA plot (Fig.5), where PC1 represents $28.14 \%$ and PC2 represents $22.5 \%$ of the total variance (SOM Figs. S9 and S10). The eigenvalues were plotted under a random model to exclude the non-significant components (Jackson, 1993). According to this analysis, PC1 to PC4 are significant for our sample. Between them, PC1 and PC2 are the best to represent the Menez Dregan technological identity. In general, maximum variability is represented by the tools made on cobbles. The shaping strategy on flakes is much more standardized through the sequence, and the indeterminate blanks (despite representing only four tools) are completely different. This pattern is supported by comparison of the midpoint distances of the Euclidean distance between the different groups (Table 7).

$$
\begin{gathered}
<\text { Fig.5> } \\
<\text { Table 7> }
\end{gathered}
$$

Modes of shaping Handaxes and cleavers are made on cobbles throughout the entire sequence, except in layer 8 , where the cobbles are specifically used to make choppers. The shaping on cobbles implies the use of at least two series of removals on tips, and only one series on the mid part (Fig. 4). The removals deeply affect the edges of the tools, creating wide denticulated cutting edges. The first series of removals is invasive, while the second is noninvasive. The butts remain cortical in most cases (Figs. 4 and 6).

$$
<\text { Fig.6> }
$$

For $83.33 \%$ of the bifaces made on large flakes (Fig. 6), the shaping processes are mainly characterized by one series of deep, noninvasive removals on the distal and mid parts. The butts show more intense shaping than on cobbles, with the combination of two series of removals, probably aiming to reduce the bulb convexity. In a few examples, we see a final retouch on the tip of the tools. The bifaces on unknown blanks are distinguished by two series of removals (invasive and noninvasive); these have a pronounced effect on the final aspect of the edges. The cortex has been reduced to produce non-cortical tools. These groups are also identified with cluster analysis (Fig. 5), where we can clearly see two main branches (unknown blanks and tools on flakes). Tools on cobbles appear separately, but share common features with flakes, mainly in the most recent layers (5 and 4).

PCA plots show that through an independent analysis of each part of the tool (distal, mid and proximal), and considering only the variables with a major effect on tool shaping (SOM Figs. S8 and S9), we can obtain complementary information. This analysis explains more variance than if we consider each tool as a single unit (Fig. 7) and reflects the different choices of the knappers, who combine various strategies depending on what is required to 
shape each part of the tool. If we consider each tool as a whole unit (Fig. 7A), PC1 and PC2 together explain $65 \%$ of the total variance (SOM Table S9) and their scores represent perfectly the variability of the sample. The location of the cortical patches, the number of removal series and the tool symmetry determine the separation of the unknown blanks, with the use of two removal series and removal of the cortex. In addition, all the handaxes and cleavers from the mid-upper part of the sequence (from layer 6 to layer 4 ) are mainly characterized by the use of hard-hammer percussion with one removal series, with cortex on the butt and mid parts and with a major trend towards symmetry. SU 6' appears as a transitional phase, sharing features both with the previous layers (mainly tools on cobbles) and with the layers that follow (tools on flakes). The PCA specifically on tool tips (Fig. 7B) explains $72 \%$ of the total variance (PC1 and PC2). Considering the type of blank groups per layer, this PCA points out the clear distance of the unknown blank group, mainly because of the specific treatment of this part of instruments. Tools on flake present a high variety of shaping strategies on tips. The tools on cobbles, localized in the upper part of the scatter plot, are mostly organized according to PC2. Most parts of the tips are shaped as part of the overall shaping of the tool, with some cortical patches and only one noninvasive series of removals. The exception concerns tools on cobbles from SU 6', which show a specific treatment of the non-cortical distal parts, with two removal series (invasive/noninvasive) and a small amount of final retouch.

$$
<\text { Fig.7> }
$$

Based on the first two PCs, the PCA on mid parts of the tools (Fig. 7C) explains 73\% of the variance, but there is a higher variability on mid parts through the sequence. The PCA on butts (PCs 1 and 2) explains $80 \%$ of the variance (Fig. 7D). In this case, the types of blanks, cobbles and flakes occupy different parts of the graph. Butts of tools made on cobbles are characterized by over $90 \%$ cortex. Tools on flakes seem to show the same features through the sequence with only one noninvasive removal series and with $40-90 \%$ cortical surface.

Metrical characterization of the handaxes and cleavers Metrically, these assemblages are standardized with elongated pieces and low values of refinement (SOM Table S8). The slight metrical differences refer to the types of blank. The tools made on cobbles are $12 \%$ bigger than those made on flakes and have the largest proximal parts (see base-length (a) in SOM Table S8). As the knapping intensity increases, mainly for tools made on unknown blanks, there is a shift of the widest part of the tool to the butt, creating shorter and wider (a) bases. In addition, these tools show a reduction of the distal width (B1, at 1/5 of length in SOM Table S8). This mid-tip shaping strategy at MDI does not affect the distal thickness (T1 in SOM Table S8), and only focuses on increasing the convergence of tool edges, generating pointed tips.

In addition, the SDI fits well with the technological and metrical data. The tools at MDI present low SDI values $(<0.01)$, which indicate a small number of removals that are $>1 \mathrm{~cm}$ with respect to the tool surface $\left(\mathrm{in}^{2}\right)$. The relation between the SDI and tool's volume is robust, stronger in the case of cobbles $\left(\mathrm{F}=12,75, p=0.01, \mathrm{r}^{2}=0.718\right)$ than flakes $(\mathrm{F}=$ $\left.37,73, p<0.01, r^{2}=0.416\right)$ or the unknown blanks $\left(F=2,86, p=0.2, r^{2}=0.589\right)$. Thus, despite the application of a low number of removals, there is a loss of information as the knapping occurs (García-Medrano et al., 2019).

Geometrics morphometrics There is clear morphological overlap between handaxes and cleavers for all of the groups considered (blank types, raw materials and layers) in the two shape trends. This overlap explains the highest proportion of variability in the sample, as reflected by the first two PCs, which explain $35.05 \%$ of the variance (Fig. 8). PC1 describes a shape ranging from pointed to globular while PC2 reflects differences in tool width and thickness. Despite the overlap between tool types, Wilcoxon rank-sum tests confirm statistically significant $(p<0.05)$ differences in mean shapes of the tools of each group (Table 8; SOM Table S10).

$$
\begin{aligned}
& <\text { Table 8> } \\
& \text { <Fig. 8> }
\end{aligned}
$$

We have combined the PCA with the extent of the intra-group shape variability, expressed as the mean multidimensional Euclidean distance of all items in a group from its 
group centroid. Results of differences between the different layers, the raw materials and the types of blank are given in Figure 8 and SOM Figs. S11 and S12. The tools on cobbles retain a large surface of the original blank and show less variability, with their shapes fitting in the middle of the flake scatter area, indicating that the cobbles used are very similar to each other. In addition, as in the technological analysis, the shaping sequence is mainly focused on the mid to distal parts of the tools, to produce pointed distal ends, with rounded, wider bases. In this case, $52.28 \%$ of their variability is accounted for by thickness.

Flakes are the most common blank and have the highest morphological variability, from pointed, thinner tools to those that are globular and thick, or from narrow to wider shapes. The mean Euclidean distance is also the highest mean value between the three blank types (Table 7) that is reflected by high width and length variation.

The unknown blanks with longer shaping sequences are observed in the more standardized group of tools, with $72 \%$ of their variability accounted for by tool thickness (Fig. 7).

In addition, the analysis of tools by raw materials points to great similarities between the most abundant materials (SOM Fig. S11), sandstone and microgranite (84.85\%), and their morphological differences are expressed according to the same parameters, mainly width and thickness. Based on the Wilcoxon Rank-Sum test, there are no statistically significant differences between them $(n 1=35, n 2=21$, rank sum $=3028, p=0.43)$. Quartzite and quartz tools are too few in number to subject to statistical analysis.

Diachronically, we cannot discern a morphological transition through the sequence. The inter-point Euclidean distance points to high variability in the assemblages, which is translated into a wide range from oval to pointed shapes in each layer, perhaps due to the small number of tools. Only layer 8 presents less heterogeneity. Throughout the sequence, this variability involves tool thickness (SOM Table S10). In fact, all layers share the central part of the PCA plot (SOM Fig. S12), and none differ statistically $(p>0.05)$ in mean shape (SOM Table S11).

Table 9 shows the summary statistics of the degree of deviation from perfect 3D bilateral and bifacial symmetry and edge regularity. Tools on cobbles have a minor bilateral symmetry ( $26 \%$ less than flakes and $38 \%$ less than unknown blanks). By contrast, flakes have the maximum edge regularity, with a clear reduction in thickness, derived from the intrinsic nature of flakes and by a more intense shaping of butts.

$$
<\text { Table 9> }
$$

\section{Discussion}

\subsection{MIS 12-8 at Menez-Dregan I: continuity in technological practice and subsistence behavior}

A local adaptation to a specific place The archaeological record for the end of MIS 12 and MIS 11 reflects new and more complex behavior in western Europe as compared with earlier occupations within this region. MDI is a good example of local adaptation of hominins to a specific place. Its long sequence shows a recurrent use of the cave from MIS 12 to MIS 8 , with an alternation of longer and shorter-term occupation with a spatial distribution of activities within the site itself and the exterior. Against this background of site use, there is the persistent use of fire and similar land-use patterns as shown by raw material acquisition. Equally, there appear to be few changes in the range of choppers, chopping tools and flake tools, nor in core technology, other than at the top of the sequence, and as this study has shown, biface technology follows the same patterns through the sequence (Table 10).

$$
<\text { Table 10> }
$$

Variation of activities and of site use The different occupations during MIS 9 are particularly informative; although there is the same use of raw materials, the numerous archaeological levels show the recurrent visit by hominins to the site, and a significantly different use of the environment by each group (Ravon, 2019). Some levels, with thick deposits and rich assemblages (SU 6', 5d', 5c', 5b', 5a'), show use of the site over fairly long or continuous periods, with a possible division of activities between the cave and its exterior. Other levels (SU $5 e, 5 d, 5 c, 5 b, 5 a)$ suggest almost exclusively a shorter-term production site, where 
most other activities were probably taking place elsewhere. However, some characteristics are more persistent during the different phases of occupation, such as the possible division of activities between the actual site and outside. This is suggested by the variation in the quantity of small retouched tools as well as their composition, and the export of some macrotools off site after shaping and probable use, shown by the high ratio of manufacturing flakes to finished tools. Variation in the type of occupation could simply be the result of abandonment and reoccupation during the climatic oscillations of MIS 9, with hominins leaving the site during the coldest phases, returning under milder conditions, but retreating once again during the climatic optimum when the sea infilled the cave (layer 6 raised beach). Despite some similar and persistent features in the lithic assemblages through time, such as the link between raw material and tool type, evidence of the use of fire and significant flake production, some differences can be highlighted between the levels. The quantity and composition of small retouched tools, for example, vary through the sequence. The human occupations of SUs $8 \mathrm{c}$ and $8 \mathrm{~b}$ display a relatively high production of small retouched tools $(6.2 \%$ and $5.6 \%$, respectively), but this tendency decreases through the sequence, clearly shifting towards an increased importance of flake production, which likely indicates different activities on site.

Variation in site function A similar pattern of occupation can be seen through the longer sequence, with the site being used both in cool phases (layers 9, 7, 4, and probably SU 5c, with pollen suggesting boreal forest), and in more temperate periods (SUs 8b, 6' and layer 5). The distance to the shoreline, therefore, varied from ca. $1 \mathrm{~km}$ across a coastal plain to perhaps 5-10 km (Table 10), through a forested plain or even steppe (Lefort et al., 2007, 2016; Monnier et al., 2016b). Located at the top of a rocky promontory, but sheltered in a marine cave, the site was likely a strategic vantage point overlooking the plain below. From this location, protected from prevailing winds, Paleolithic groups could monitor large herbivore herds that were likely to graze and water on the plain below. Depending on the period, the cave functioned as a dwelling place, as evidenced by the production and use of tools and the presence of hearths, or more as a place of manufacture with tool-use undertaken offsite. This variation in site function reflects a slightly different organization of place according to the occupation, activity and climatic context. Despite the poor preservation of faunal remains, usually as decayed traces, micromorphology has revealed bone charcoal throughout the sequence, other than layer 4 (Monnier et al., 1996a:23). New samples taken in 2020 for this layer are yet to be analyzed. The near-constant presence of faunal remains through the sequence, always associated with lithic artifacts, likely indicates butchery activities or food consumption on site. All the levels of human occupation present a partition of activities between the site itself and the exterior, in different ways.

Link between raw materials and tool types The raw materials show a high petrographic diversity reflecting the complex geology of the Armorican Massif. Initially, all the knapped raw materials were available locally (flint, quartz, quartzite, sandstone, and microgranite), and from layer 8 onwards there was the use of glossy sandstone, which was available $20 \mathrm{~km}$ away and implies a different use of the landscape from this stage. MDI also points to a clear selection of materials with the débitage persistently knapped on flint, quartz and glossy sandstone, while façonnage was mainly on sandstone, microgranite and quartzite. This link between raw materials and tool types persists between MIS 12-8: the apparent homogeneity of the lithic industries of MDI indicates an environmental constraint, where flint is only available as small marine pebbles, leading the hominins to select other raw materials on the fossil beaches surrounding the site for the manufacture of the heavy-duty tools. The glossy sandstone is almost entirely absent in the oldest levels (layer 9 and SU 8c; Table 4), suggesting a different territory or type of mobility, paleogeography or access to raw materials for these early occupations (Lefort et al., 2016; Ravon, 2017a, b). The selection of raw materials and the link between raw material selection and tool type is a consistent feature of the lithic technology at MDI through time, with flint, quartz and glossy sandstone used specifically for the flakes and small tool production, while larger cobbles of sandstone and microgranite are shaped into macro-tools, demonstrating an adaptation of choices and practices to a specific environment and landscape, but also a transmission of knowledge and habits within a group through several generations.

Core technologies All the débitage seems to have been undertaken on site, as indicated by the presence of cores, flakes, flake fragments, percussors, and knapping chips. The main 
activity on site seems to have been the production of flakes, which totals $54 \%$ of the lithic assemblages, and up to $90 \%$ if flake fragments are included. Macro-tools and small retouched tools each contribute $2 \%$ in total to the assemblages. Throughout, core technologies were opportunistic without predetermination and with a complete absence of the Levallois method. However, bipolar flaking on an anvil was used in all the SUs, and was systematically applied to initially open the smaller pebbles in SU 4ab, attesting to a less opportunistic behavior and adaptation to raw material size (Ravon and Monnier, 2013; Ravon et al., 2016, 2017a). This technological solution, used to produce shorter, thicker flakes with a natural back that were suitable blanks for retouched tools, together with the presence of two discoid cores in SU 4ab, has been interpreted as the beginning of the transition to the Middle Paleolithic (Ravon and Monnier, 2013; Ravon et al., 2016a).

Constant shaping strategies The shaping strategies remain constant through the MDI sequence. There is a large use of sandstone and microgranite for shaping crude handaxes, and in some cases, classic cleavers on flakes with unretouched distal ends. The tools present different technological features according to the type of blank used. Tools on cobbles are shaped using two series of removals on tips, one series on mid parts and the butts remain mainly cortical, preserving a good part of the original cobble or pebble features. Flakes are the preferred blanks, and their shaping strategy usually consists of the use of only one series of removals on tips and mid parts, and one or two series on butts, mainly to reduce the bulb of the original flake. In fact, there is a clear reduction of thickness on those pieces. The tools on unknown blanks are non-cortical with a combination of two removal series (invasive and noninvasive) on the whole perimeter. Whatever the strategy, the number of removals is low and the effect on the edges is deep, generating denticulated plan shapes. The knappers' intentions seem to have been to give the tools their general shape without any care for the edges. This produced high morphometrical variability with pointed to oval shapes, independent of blank type, raw material or level. The tools on cobbles retain a large surface of the original blank and show less variability, with their shapes fitting in the middle of the flake scatter area, indicating that the cobbles used are very similar to each other, attesting to a specific selection by the knappers. Despite the fact that most of the blanks are flakes, and that the lithic assemblages include $0.7 \%$ of large flakes (i.e., where length $>10 \mathrm{~cm}$ ), the cores that produced these blanks are entirely absent from the collection. This points to two hypotheses: 1) large flakes were produced outside of MDI, then brought into the cave, emphasizing the division between activities at the site itself and its exterior; and/or 2) large flakes were produced in situ, but the larger cores they come from were intensively knapped or transformed and therefore are not apparent in the lithic assemblages, except possibly as cobble fragments, or as indeterminate materials.

Constant presence of LCTs, but intermittent presence of handaxes and cleavers The systematic use of pebbles and/or cobbles explains the constant presence of LCTs through the whole sequence, with macro-tools such as choppers and chopping tools (SOM Fig. S7) in all the levels (Table 1). Nevertheless, the occurrence of handaxes and cleavers is intermittent. While the choppers have been shaped at the site and then left in the same place, handaxes and cleavers seem to be shaped in situ and then transported out of the cave, particularly those made from flint and glossy sandstone. The ratio between flakes from shaping sequences and the number of scars on the LCT surfaces indicate an overrepresentation of these flakes. This clearly represents a different treatment of these tool types, with a higher mobility for handaxes and cleavers. Mobility of tools and different site functions through time are part of the explanation for the intermittent presence of handaxes and cleavers at the site. In SU $5 d$, the quantity of artifacts is low and there are no handaxes or biface thinning flakes. In SU 5c' handaxes are also absent, but choppers and cleavers are present. It is probable that in the thicker stratigraphic units, where much higher numbers of artifacts are suggestive of longer-term occupation, the main activities were undertaken outside the cave. In SU 5c, the most structured fireplace of the sequence has been interpreted as the center of domestic activities in the cave (Ravon, 2017a, 2019). But, in this case, the retouched/shaped tools (likely used in butchery processes) have likely been made outside the cave. So, for the sequence of MDI, the intermittent presence of handaxes could be the result of different distributions of activities, where the shaped and retouched tools are transported out of the cave, and the main flaking and domestic activities were undertaken inside. It is notable that the youngest archaeological level (SU 4ab) has the highest 
percentages of handaxes and cleavers. It also has a pavement structure and is interpreted as a site for both production and other activities. The high number of centripetal cores and two discoid cores suggests that this level marks the transition to the Middle Paleolithic.

In some cases, it has been suggested that the presence or absence of handaxes and cleavers through the sequence could reflect the use of the cave by different groups with different technological traditions (Ravon, 2019). Although choppers are always present, handaxes and cleavers are totally absent in SU 5d, 5c and $5 b$ (Table 1), which were shorterterm occupational contexts. This absence could be due to small sample size, as these SUs show the lowest number of artifacts on site. However, the shaping strategy remains constant through the whole sequence, with the main technological differences relating to the use of different types of blank. So, there are no technological changes or disconnections through time. Equally, the different spatial distributions of activities (in and outside the cave) likely generates the movement of the tools, depending on their use or production goals, resulting in the presence or absence of these types of tools in the archaeological record. These are particularly marked with relatively high percentages of handaxes and cleavers in SU 8b and 7, and particularly in SU 4ab (Table 1).

\subsection{MDI in the context of late Middle Pleistocene Europe}

The evidence from MDI illustrates a highly regional expression of human behavior between MIS 12 and MIS 8. It shows dynamic use of the site within a changing climate and environment, but also suggests continuity in technological practice and subsistence behavior throughout the period until the first signs of Middle Paleolithic core reduction methods.

New practices and behavorial shifts Elsewhere in Europe there is not only continuity in technological practice, but also development of established techniques, or possible innovation in some cases. There was continuity from MIS 13 in core technology with the widespread use of unipolar, bipolar and orthogonal methods at most sites, including MDI, with resulting flake tools dominated by notches, denticulates and more rarely scrapers (Moncel et al., 2015; Davis and Ashton, 2019; de Lombera-Hermida et al., 2020; Rawlinson et al., submitted). But new behaviors are also apparent, reflected by more complex prepared core technologies, first evident from MIS 12. Multiple origins are suggested by the variety of methods from re-purposing of bifaces at Cagny-la-Garenne in MIS 12 (France; Lamotte and Tuffreau, 2001) to Levallois technology at Guado San Nicola in late MIS 11 (Italy; Peretto et al., 2016) and sites such as Orgnac, Aldène (both France), Cave Dall'Olio (Italy), Nor Geghi 1 (Armenia) and Purfleet (UK) in MIS 9 (White and Ashton, 2003; Moncel et al., 2011, 2012, 2020b; Scott, 2011; Scott and Ashton, 2011; Fontana et al., 2013; Turq et al., 2013; Adler et al., 2014; Rossoni-Notter et al. 2016). Both debitage and façonnage was increasingly used to produce standardized products, although many other sites maintained bifacial technology in association with simpler core reduction methods (i.e., Herisson et al., 2012; Moncel et al., 2015; Davis and Ashton, 2019).

The diversity of technological systems suggests a mosaic of rhythms of hominin dispersal that result in a multitude of behavioral expressions in different areas (Moncel et al., 2012; Wiśniewski, 2014). In central Europe and the northern Caucasus, evidence suggests that this region may be disconnected from traditions in western Europe (Doronichev and Golovanova, 2010; Doronichev, 2016) with the later arrival of new technologies during more favorable climate (Wiśniewski, 2014). In western Europe, the diversity of the lithic assemblages is illustrated by the range of biface forms. The production of cleavers on flakes, considered as classical African cleavers, is mainly evident in southern France and northern Spain, where raw materials allowed the production of large flakes as blanks. By contrast, the predominance of flint in north-western Europe, allowed the production of a wide variety of biface forms, including those with a bifacially flaked transverse edge, which could be interpreted as atypical cleavers.

Despite these potentially specific functional forms, there was enormous variation in handaxe morphology, from ovate and cordiform types with soft-hammer flaking, such as La Noira stratum c (Moncel et al., in press), La Grande Vallée (Hérisson et al., 2012), Galería (Garcia-Medrano et al., 2015) and Elveden (Ashton et al., 2005), to more pointed forms at Cagny-la-Garenne (Lamotte and Tuffreau, 2001) and Swanscombe Middle Gravels (Ashton, 
2016), or those more crudely shaped, such as at Terra Amata (de Lumley, 2009; de Lumley et al., 2015; Viallet, 2016) and MDI. As with cleavers, it has long being suggested that some of this variation can be attributed to raw material quality and blank form (Villa, 1981; Ashton and McNabb, 1994; White, 1998), and this seems to be the case at MDI and even more clearly at Terra Amata, where a few crudely made handaxes and cleavers were made on local limestone beach pebbles (de Lumley, 2009; de Lumley et al., 2015). To add to the variation in form and raw material, there are several sites in Italy where bone was also used for handaxe manufacture (Boschian and Saccà, 2015; Santucci et al., 2016; Zutovski and Barkai, 2016). The variation in handaxe morphology seems to continue into MIS 10 and 9 , as clearly shown at MDI. Although distinctions between north and south may simply relate to differences in raw material, alternatively the use of large flakes in southern Europe could have been connected to the arrival of groups related to the Large Flake assemblage tradition from the Levant with tools that bear African features (Sharon et al., 2009; Moncel et al., 2015; Sharon and Barsky, 2016).

One of the features of some sites from MIS 11 to 9 is the apparent absence of biface technology. Although this is a characteristic of some levels at MDI, this may be explained through small sample size or varying use of the internal part of the cave. Elsewhere, such as sites without handaxes in the UK (Barnham unit 5, Clacton and Swanscombe Lower Gravel) or in central Europe (e.g., Bilzingsleben and Schöningen; Julien et al., 2015), it appears to have been a technological or cultural choice, again reflective of regional traditions of knapping (Ashton et al., 2016; Davis and Ashton, 2019).

Through this period of MIS 13 to MIS 9, there is also evidence of new subsistence behaviors with an increase in hunting vs. scavenging, that suggests the development of skills, communication and social interaction (e.g., Gran Dolina TD6 and TD 10-1, Boxgrove and Schöningen; Roberts and Parfitt, 1999; Stiner et al., 2009; Rodríguez-Hidalgo et al., 2011 ; 2015; Blain et al., 2021). Management of local game resources is also evident with seasonal settlement and evidence of specialized hunting in territorial networks, such as at Orgnac 3 (Moncel et al., 2012). Systematic butchery can be seen on ungulate and small game carcasses. Bone tools only rarely survive, but dispersed evidence reflects widespread use (Brühl, 2003; Julien et al., 2015; van Kolfschoten et al., 2015; Moigne et al., 2016; Zutovski and Barkai, 2016). Alongside these developments we see better evidence for fireuse from MIS 11 at Beeches Pit (UK), Terra Amata (France) and Gruta da Aroeira (Portugal), together with MDI (Gowlett et al. 2005; Roebroeks and Villa, 2011; de Lumley et al., 2015; Sanz et al., 2020).

How do we begin to understand the complexity of these developments? The establishment of new practices shows behavioral shifts or thresholds that were achieved through the accumulation of knowledge after long periods of apparent stasis where invention and innovation may have occurred, but were not firmly embedded. The catalysts for the innovations in the long interglacial of MIS 11 may have been due to a variety of reasons from climatic change, population dispersal and local hominin evolution, to demographic expansion with better networks for communication and establishment of new ideas or increased cultural innovation rates over time (Ollé et al., 2016; Davis and Ashton, 2019; Moncel et al., 2020b, c, d; Blain et al., 2021; Barsky et al., 2021; Ashton and Davis, 2021). Due to its long sequence that begins in this critical period, MDI can help to throw some light on these questions. Although most technological practices were well-established prior to MIS 12, at MDI there is the innovation of fire use, a flexible use of the site and the clear understanding of local territory. These practices enabled a more permanent occupation of MDI with comparatively little change in the archaeological signatures.

Towards an identification of regional patterning? On a broader scale, more complex regional patterning is becoming increasingly identifiable through better chronological frameworks and correlation between sites. Previous authors (Davis and Ashton, 2019; Ashton and Davis, 2021) have put forward the 'Cultural Mosaic Model', whereby populations in stable environments developed material culture that reflected the resources and configuration of the landscape in which they lived. The model proposes that changes in climate would have led to instability and population movement, which would have been more accentuated in northern Europe. They argue that Britain's record shows repeated population incursions, retreats and extinctions that was governed by cyclical climate change, but that each 
incursion had a distinctive material culture that reflected the technological and cultural complexity of mainland Europe. They further propose that more southerly sites were buffered against climatic variation, particularly those situated in caves or rockshelters, resulting in more continuity in occupation, behavioral practices and material culture.

The model is supported by the evidence from MDI, which provides a striking contrast to the sites in Britain. Despite variation in the proportions of tool types and activities within the site, MDI reveals remarkable continuity in raw material selection and technological practices. This could be argued to be merely a response by different populations to the same environmental situation and its resources, but there are two important aspects that argue against this. First, one of the technological practices is the persistent use of fire, whether represented by hearths or by large quantities of charcoal, burnt bone and flint. As a technology, controlled fire use requires complex knowledge and strong systems of social learning to ensure long-term practice. Its rarity elsewhere in Europe reflects the difficulty of maintaining this technology (Gowlett et al., 2005; Roebroeks and Villa, 2011) and strongly suggest that at MDI there was cultural continuity with robust social structures to ensure successful knowledge transfer (MacDonald et al., 2021). Second, MDI shows the persistent use of glossy sandstone from $20 \mathrm{~km}$ away, after MIS 12. Knowledge of this rare resource shows a deep understanding of the landscape and implies successful transfer of this knowledge down multiple generations.

The distance of $20 \mathrm{~km}$ for the import of raw materials is similar to other import distances for Lower Paleolithic sites. At the MIS 14-12 site of Caune de l'Arago raw material was brought in from over $30 \mathrm{~km}$ (Barsky, 2013). Unusually, flint handaxes were brought from over $60 \mathrm{~km}$ to the MIS 13 site of Waverley Wood (Keen et al., 2006). For MIS 11, distances of 20 $\mathrm{km}$ away are recorded at Ambrona (Santonja et al., 2018), $30 \mathrm{~km}$ to up to $100 \mathrm{~km}$ for La Noira stratum c for some stones (Moncel et al., in press), while for MIS 9, Wolvercote has distances of $25 \mathrm{~km}$ (Ashton, 2001) and Orgnac $15 \mathrm{~km}$ (Moncel et al., 2011, 2012). It has been suggested that an annual territory with a radius of 20 to $30 \mathrm{~km}$ would be viable for a network of interconnected cultural groups of 100 to 200 people (Davis and Ashton, 2019; Ashton and Davis, 2021). These figures also conform with the predicted group size of 120 150 for Middle Pleistocene hominins according to the social brain hypothesis (Dunbar, 1998, 2003). MDI provides an important site and landscape for beginning to understand a territory, its use and social networks during the late Middle Pleistocene.

The persistence in technological practices at MDI suggests that even though hominins may have abandoned the site during the very coldest and warmest parts of the climatic cycles, cultural continuity was maintained with perhaps only slight shifts in occupation. This provides important evidence for hominin ability to survive in harsh environments, and perhaps indicates the north-western boundary for continuous occupation during the late Middle Pleistocene. It seems that the site's location in a cave, near the coast with access to marine resources and an oceanic climate, provided the right set of conditions for permanent hominin presence. These conditions have been argued to be important more broadly for the occupation of northern Europe during the Middle Pleistocene (Parfitt et al., 2010; Cohen et al, 2012; Hosfield, 2016, 2020) and MDI supports this interpretation of hominin adaptation to Europe and colonization of northern latitudes.

\section{Conclusions}

At the end of MIS 12 and during MIS 11 the archaeological record in western Europe shows an increase in the number of sites, greater variability between sites and the innovation of new practices when compared with earlier sites within the region. MDI appears to show the local adaptation of hominins to this specific place. Its long sequence reflects a recurrent use of the cave from MIS 12 to MIS 8, with alternating long and shorter-term occupations and a spatial distribution of activities between the site itself and the exterior, together with a persistent presence of fire, which enabled a repeated use of this place, even under colder conditions. Despite similar and constant features in the lithic assemblages at MDI through time, such as the link between raw materials and tool types, and the significant flake production, some differences exist between the levels, as seen in the composition of the lithic assemblages in the different occupations, which suggest different activities on site. In contrast, the shaping strategy remains constant through the whole sequence, with the 
main technological differences only relating to the use of different types of blanks, and there are no technological changes or disconnections through time.

While it has been suggested that the presence/absence of handaxes and cleavers through the sequence could possibly reflect the use of the cave by different groups with different technological traditions, the spatial distribution of activities in and outside the site can just as well explain their presence or absence in the assemblages through time. There is strong evidence for continuity in localized traditions, as particularly shown by the persistent use of raw material from $20 \mathrm{~km}$ away, and by the use of fire. Therefore Menez-Dregan is an excellent example of local and cultural adaptations to a specific landscape with a clear effect on the acquisition and management of raw materials. The length of the occupation, with a strong tradition of landscape use and material culture, reflects the flexibility of hominin populations to cope with the cyclical changes in climate from this part of Europe from MIS 11. The MDI record stands in contrast to the punctuated archaeological signal from areas of northern Europe, such as Britain, and may mark the boundary between continuous occupation in southern Europe and areas to the north.

\section{Acknowledgments}

This research was supported by the project 'Understanding a threshold in Human evolution at 450-350 ka through the roots of Neanderthal behavior (Neandroots)' (ANR-19CE27-0011). P. Garcia-Medrano has been funded by the European Union's Horizon 2020 research and innovation program under a Marie Sklodowska-Curie project, 'Western European Acheulean project, WEAP' (Grant Agreement n.748316). The University of Bradford and Adrian Evans, through the 'Fragmented Heritage AHRC Project', leant us the scanner for working on Levels 6 to 8. We thank the UMR $6566 \mathrm{CReAAH}$ at the University of Rennes 1 , for lending us a portable scanner to complete our study (layers 4 and 5), and the French Ministry of Culture, the Department of Finistère and the city of Plouhinec, which supported this work through continuous funding for the excavations and post-excavation work at Menez-Dregan since 1988. We are thankful to the Hebrew University of Jerusalem, Leore Grosman and Antoine Muller, who helped us with the Artifact3-D and AGMT3-D software management. This work was developed between the Institut de Paléontologie Humaine (Muséum national d'Histoire naturelle, Paris), Department of Britain, Europe and Prehistory, Franks House (British Museum), and the Institut Català de Paleoecologia Humana i Evolució Social (IPHES-CERCA, Spain). The latter received financial support from the Spanish Ministry of Science and Innovation through the 'María de Maeztu' program for Units of Excellence (CEX2019-000945-M)'. N. Ashton's contribution was part of the 'Pathways to Ancient Britain' project, funded by the Calleva Foundation.

\section{References}

Adler, D.S., Wilkinson, K.N., Blockley, S., Mark, D.F., Pinhasi, R., Schmidt-Magee, B.A., Nahapetyan, S., Mallol, C., Berna, F., Glauberman, P.J., 2014. Early Levallois technology and the Lower to Middle Paleolithic transition in the Southern Caucasus. Science 345, 16091613.

Antoine, P., Moncel, M.-H., Locht, J.-L., Bahain, J.-J., Voinchet, P., Hérisson, D., Hurel, A., 2019. The earliest record of Acheulean human occupation in North-West Europe. Sci. Rep. 9, 13091.

Ashton, N.M., 2001. One step beyond. Flint shortage above the Goring Gap: The example of Wolvercote. In: S. Milliken, J. Cook (Eds.), A Very Remote Period Indeed: Papers on the Palaeolithic Presented to Derek Roe. Oxbow, Oxford, pp. 199-206.

Ashton, N.M., 2015. Ecological niches, technological developments and physical adaptations of early humans in Europe: The handaxe-heidelbergensis hypothesis. In: Wenban-Smith, F. Coward, F., Hosfield, R., (Eds.), Settlement, Society and Cognition in Human Evolution: Landscapes in Mind. Cambridge University Press, Cambridge, pp. 138-153.

Ashton, N.M., 2016. The human occupation of Britain during the Hoxnian Interglacial. Quat. Int. 409, 41-53. 
Ashton, N.M., Davis, R.J., 2021. Cultural mosaics, social structure and identity: The Acheulean threshold in Europe. J. Hum. Evol. 156, 103011.

Ashton, N.M., Lewis, S.G., 2012. The environmental contexts of early human occupation of northwest Europe: The British Lower Palaeolithic record. Quat. Int. 271, 50-64.

Ashton, N. M., McNabb, J., 1994. Bifaces in perspective. Lithic Studies Society Occasional Paper 4, 182-191.

Ashton, N., Lewis, S., Parfitt, S., Candy, I., Keen, D., Kemp, R., Penkman, K., Thomas, G., Whittaker, J., White, M., 2005. Excavations at the Lower Palaeolithic site at Elveden, Suffolk, UK. Proc. Prehist. Soc. 71, 1-61.

Ashton, N., Lewis, S.G., Parfitt, S., Davis, R., Stringer, C., 2016. Handaxe and non-handaxe assemblages during Marine Isotope Stage 11 in northern Europe: Recent investigations at Barnham, Suffolk, UK. J. Quat. Sci. 31, 837-843.

Ballèvre, M., Bosse, V., Dabard, M.-P., Ducassou, C., Fourcade, S., Paquette, J.-L., Peucat, J.-L., Pitra, P., 2013. Histoire Géologique du massif Armoricain: Actualité de la recherche. Bull. Soc. Géol. Minéral. Bretagne D, 10-11, 5-96.

Barsky, D., 2013. The Caune de l'Arago stone industries in their stratigraphical context. C.R. Palevol. 12, 305-325.

Barsky, D., Moigne, A.-M., Pois, V., 2019. The shift from typical Western European Late Acheulian to microproduction in unit ' $D$ ' of the late Middle Pleistocene deposits of the Caune de l'Arago (Pyrénées-Orientales, France), J. Hum. Evol. 135, 102650.

Barsky, D., Carbonell, E., Sala-Ramos, R., Bermúdez de Castro, J. M., García-Vadillo, F. J. 2021. Late Acheulian multiplicity in manufactured stone culture at the end of the Middle Pleistocene in Western Europe. Quat. Int. https://doi.org/10.1016/i.quaint.2021.04.017

Bermúdez de Castro, J. M., Martinón-Torres, M., Blasco, R., Rosell, J., Carbonell, E., 2013. Continuity or discontinuity in the European Early Pleistocene human settlement: The Atapuerca evidence. Quat. Sci. Rev. 76, 53-65.

Blain, H-A., Fagoaga, A., Ruiz-Sanchez, F.J., García-Medrano, P., Ollé, A., Jiménez-Arena, J.M., 2021. Coping with arid environments: A critical threshold for human expansion in Europe at the Marine Isotope Stage 12/11 transition? The case of the Iberian Peninsula. J. Hum. Evol. 153, 102950.

Boëda, É., 1991. Approche de la variabilité des systèmes de production lithique des industries du Paléolithique inférieur et moyen : Chronique d'une variabilité attendue, Tech. Cult. 17-18, 37-79.

Bordes, F., 1961. Typologie du Paléolithique Ancien et Moyen. Mémoire n¹. Publications de l'Institut de Préhistoire de l'Université de Bordeaux.

Boschian, G., Saccà, D., 2015. In the elephant, everything is good: Carcass use and reuse at Castel di Guido (Italy). Quat. Int. 361, 288-296.

Brühl, E., 2003. The small tool industry from Bilzingsleben, Steinrinne. In: Burdukiewicz, J.M., Ronen, A. (Eds.), Lower Palaeolithic Small Tools in Europe and the Levant. BAR-IS 1115, Archaeopress, Oxford, pp. 49-63.

Capdevielle, J., Ravon, A.-L., 2021. Analyse technotypologique des hachereaux et autres macro-outils à tranchant transversal de Menez- Dregan I (Plouhinec, Finistère). Bull. Soc. Préhist. Française 118, 2, 215-243.

Clarkson, C., 2013. Measuring core reduction using 3D flake scar density: A test case of changing core reduction at Klasies River mouth, South Africa. J. Archaeol. Sci. 40, 43484357.

Cohen, K.M., MacDonald, K., Joordens, J.C.A., Roebroeks, W., Gibbard, P.L., 2012. The earliest occupation of north-west Europe: A coastal perspective. Quat. Int. 271, 70-83.

Costa, A.G., 2010. A geometric morphometric assessment of plan shape in bone and stone Acheulean bifaces from the Middle Pleistocene site of Castel di Guido, Latium, Italy. In: 
Lycett S., Chauhan P. (Eds.), New Perspectives on Old Stones. Springer, New York, pp. 2341.

Davis, R., Ashton, N., 2019. Landscapes, environments and societies: The development of culture in Lower Palaeolithic Europe. J. Anthropol. Archaeol. 56, 101107.

Davis, R.J., Ashton, N.M., Hatch, M.T., Hoare, P.G., Lewis, S.G., 2021. Palaeolithic archaeology of the Bytham River: Human occupation of Britain during the early Middle Pleistocene and its European context. J. Quat. Sci. 36, 526-546.

de Lombera-Hermida, A., Pedro Rodríguez-Álvarez, X., Peña, L., Sala-Ramos, R., Despriée, J., Moncel, M.-H., Gourcimault, G., Voinchet, P., Falguères, C., 2016. The lithic assemblage from Pont-de-Lavaud (Indre, France) and the role of the bipolar-on-anvil technique in the Lower and Early Middle Pleistocene technology. J. Anthropol. Archaeol. 41, 159-184,

de Lombera-Hermida, A., Pedro Rodríguez-Alvarez, X., Mosquera, M., Ollé, A., GarcíaMedrano, P., Pedergnana, A., Terradillos-Bernal, M., Lopez-Ortega, E., Bargalló, A., Rodríguez-Hidalgo, R. Saladié, P., María Bermúdez de Castro, J., Carbonell, E., 2020. The dawn of the Middle Paleolithic in Atapuerca: The lithic assemblage of TD10.1 from Gran Dolina. J. Hum. Evol., 102812.

de Lumley H., 2009. Terra Amata, Nice, Alpes-Maritime. Des campements acheuléens datés de 400000 à 380000 ans. CNRS Éditions.

de Lumley, H., Cauche, D., El Guennouni, K., Fournier, A., Grégoire, S., Lecervoisier, B., Notter, O., Pollet, G., Roger, T., Rossoni-Notter, E., Roussel, B., Viallet, C., 2015. Terra Amata - Les Industries Acheuléennes. Tome IV, Editions CNRS, Paris.

Dennell R., Roebroeks W., 1996. The earliest colonization of Europe: The short chronology revisited. Antiquity 70, 535-542.

Dennell, R., Martinón-Torres, M., Bermúdez de Castro, J.M., 2011. Hominin variability, climatic instability and population demography in Middle Pleistocene Europe. Quat. Sci. Rev. 30, 1511-1524.

Donnart, K., Naudinot, N., Le Clézio, L., 2009. Approche expérimentale du débitage bipolaire sur enclume: Caractérisation des produits et analyse des outils de production. Bull. Soc. Préhist. Française 106, 517-533.

Doronichev, V., 2016. The Pre-Mousterian industrial complex in Europe between 400 and $300 \mathrm{ka}$ : Interpreting its origin and spatiotemporal variability. Quat. Int. 409, 222-240

Doronichev, V., Golovanova, L. V, 2010. Beyond the Acheulean: A view on the Lower Paleolithic occupation of Western Eurasia. Quat. Int. 223-224, 327-344.

Dunbar, R.I.M., 1998. The social brain hypothesis. Evol. Anthropol. 6, 178-190.

Dunbar, R.J.M., 2003. The social brain: Mind, language and society in evolutionary perspective. Annu. Rev. Anthropol. 32, 163-181.

Fontana, F., Moncel, M.-H., Nenzioni, G., Onorevoli, G., Peretto, C., Combier, J., 2013. Widespread diffusion of technical innovations around 300,000 years ago in Europe as a reflection of anthropological and social transformations? New comparative data from the western Mediterranean sites of Orgnac (France) and Cave dall'Olio (Italy). J. Anthropol. Archaeol. 32, 478-498.

Gaillard, C., Ravon, A.-L., Monnier, J.-L., Hallégouët, B., Laforge, M., Hinguant, S., Marguerie, D., Van Lliet-Lanoë, B., Marcoux, N., Aoustin, D., Le Bailly, M., Falguères, C., Bahain, J.-J., Guérin, G., Mercier, N., Voinchet, P., Courty, M.-A., Chantreau, Y., Sellami, F., 2016. Plouhinec (Finistère), Menez-Dregan I, Des Prénéandertaliens aux Néandertaliens, les premières occupations paléolithiques. Rapport intermédiaire de fouille programmée. CNRS-UMR 6566 CReAAH, CNRS-UMR 7194 HNHP, Université de Rennes 1, Ministère de la Culture et de la Communication, MNHN, Conseil Général du Finistère, Mairie de Plouhinec.

Gamble, C., 2018. Thresholds in human complexity in the Middle Pleistocene. A persistent places approach. In: Pope, M., McNabb, J., Gamble, C. (Eds.), Crossing the Human Threshold. Routledge, London, pp. 3-23. 
García-Medrano, P., 2020. 3D Models from Menez Dregan I site (Plouhinec, Finistère, France). ZENODO https://doi.org/10.5281/zenodo.4319919

García-Medrano, P., Ollé, A., Mosquera, M., Cáceres, I., Díez, C., Carbonell, E., 2014. The earliest Acheulean technology at Atapuerca (Burgos, Spain): Oldest levels of the Galería site (GII Unit). Quat. Int. 353, 170-194.

García-Medrano, P., Ollé, A., Mosquera, M., Cáceres, I., Carbonell, E., 2015. The nature of technological changes: the Middle Pleistocene stone tool assemblages from Galería and Gran Dolina-subunit TD10. 1 (Atapuerca, Spain). Quat. Int. 368, 92-111.

García-Medrano, P., Ollé, A., Roberts, M. B., Ashton, N., 2019. The mental template in handaxe manufacture: New insights into Acheulean lithic technological behaviour at Boxgrove, Sussex, UK. J. Archaeol. Method Theory 26, 396-422.

García-Medrano, P., Ashton, N., Moncel, M.H., Ollé, A., 2020a. The WEAP Method: A new age in the analysis of the Acheulean handaxes. J. Paleolit. Archaeol. 3, 756-793.

García-Medrano, P., Maldonado-Garrido, E., Ashton, N., Ollé, A., 2020b. Objectifying processes: The use of geometric morphometrics and multivariate analyses on Acheulean tools. J. Lithic Studies 7, 1.

Geneste, J.-M., 1991. Systèmes techniques de production lithique: Variations technoéconomiques dans les processus de réalisation des outillages paléolithiques, Tech. Cult. 1718, 1-35.

Gowlett, J.A.J. Hallos, J., Hounsell, S., Brant, V., Debenham, N.C., 2005. Beeches Pit archaeology, assemblage dynamics and early fire history of a Middle Pleistocene site in East Anglia, UK. Eurasian Prehist. 3, 3-38.

Grosman, L., Smikt, O., Smilansky, U., 2008. On the application of 3-D scanning technology for the documentation and typology of lithic artifacts. J. Archaeol. Sci. 35, 3101-3110.

Hammer, Ø., Harper, D. A. T., 2006. Paleontological data analysis. Blackwell Publishing, Malden.

Hérisson, D., Airvaux, J., Lenoble, A., Richter, D., Claud, E., Primault, J., 2012. Le gisement acheuléen de La Grande vallée à Colombiers (Vienne, France) : Stratigraphie, processus de formation, datations préliminaires et industries lithiques. Paleo 23, 137-154.

Herzlinger, G., Goren-Inbar, N., 2019. Do a few tools necessarily mean a few people? A techno-morphological approach to the question of group size at Gesher Benot Ya'aqov, Israel. J. Hum. Evol. 128, 45-58.

Herzlinger, G., Goren-Inbar, N., 2020. Beyond a cutting edge: A morpho-technological analysis of Acheulian handaxes and cleavers from Gesher Benot Ya'aqov, Israel. J. Paleolit. Archaeol. 3, 33-58.

Herzlinger, G., Grosman, L., 2018. AGMT3-D: A software for 3-D landmarks-based geometric morphometric shape analysis of archaeological artifacts. PLoS One13, e0207890.

Herzlinger, G., Goren-Inbar, N., Grosman, L., 2017. A new method for 3D geometric morphometric shape analysis: The case study of handaxe knapping skill. Archaeol. Sci. Rep. 14, 163-173.

Hoggard, C.S., McNabb, J., Cole, J.N., 2019. The application of elliptic Fourier analysis in understanding biface shape and symmetry through the British Acheulean. J. Paleolit. Archaeol. 2, 115-133.

Hosfield, R.T., 2016. Walking in a winter wonderland? Strategies for Early and Middle Pleistocene survival in midlatitude Europe. Curr. Anthropol. 57, 653-682.

Hosfield, R.T., 2020. The Earliest Europeans. A year in the Life: Seasonal Survival Strategies in the Lower Palaeolithic. Oxbow Books, Oxford.

Hublin, J. J., 2009. The origin of Neandertals. Proc. Natl. Acad. Sci. USA 106, 16022-16027. Hublin, J.-J., Pääbo, S., 2005. Neandertals. Curr. Biol. 16, 113-114. 
lovita, R., McPherron, S., 2011. The handaxe reloaded: A morphometric reassessment of Acheulian and Middle Paleolithic handaxes. J. Hum. Evol. 61, 61-74.

Jackson, D.A., 1993. Stopping rules in principal components analysis: a comparison of heuristical and statistical approaches. Ecology 74, 2204-2214.

Julien, M.-A., Hardy, B., Stahlschmidt, M.C., Urban, B., Serangeli, J., Conard, N.J., 2015. Characterizing the Lower Paleolithic bone industry from Schöningen 12 II: A multi-proxy study. J. Hum. Evol. 89, 264-286.

Keen, D.H., Hardaker, T., Lang, A.T.O., 2006. A Lower Palaeolithic industry from the Cromerian (MIS 13) Baginton Formation of Waverley Wood and Wood Farm Pits, Bubbenhall, Warwickshire, UK. J. Quat. Sci. 21, 457-470.

Laforge, M., 2012. Le cadre chronostratigraphique des peuplements pléistocènes de l'Ouest de la France. Eustatisme, changements climatiques et occupations humaines. Ph.D. Dissertation, Université Rennes 1.

Laforge, M., Monnier, J.-L., 2011. Contribution à la chronostratigraphie du gisement Paléolithique inférieur de Menez-Dregan I (Plouhinec, Finistère, France). Corrélations avec les dépôts Pléistocènes de la falaise de Gwendrez. Quaternaire 2, 91-104.

Lamotte, A., Tuffreau, A., 2001. Les industries lithiques de Cagny-la-Garenne II (Somme). In: Tuffreau, A. (Ed.), L'Acheuléen dans la vallée de la Somme et Paléolithique moyen dans le nord de la France: Données récentes. CERP n6, pp. 59-91.

Laurent, M., Falguères, C., Michel, V., Bahain, J.-J., Masaoudi, H.I., 1998. Caractérisation de structures de combustion par l'utilisation de mesures physiques. In: Peretto, C., Giunchi, C. (Eds.), Proceedings of the XIII UISPP Congress, vol. 1: Theoretical and Methodological Problems, Archaeometry, Paleoecology, A.B.A.C.O. Edizioni, Forlì, Italy, pp. 313-320.

Lefort, J.-P., Monnier, J.-L., Marcoux, N., 2007. Apport de la géologie marine à la détermination des sources de matières premières au Paléolithique dans le massif armoricain: Origine possible du silex utilisé sur les stations Paléolithique inférieur de MenezDregan (Plouhinec, Finistère, France). Implications paléoclimatiques et paléoenvironnementales. Quaternaire 18, 233-241.

Lefort, J.-P., Monnier, J.-L., Danukalova, G., Ravon, A.-L., 2016. Evolution of the Palaeolithic landscape at the western most tip of continental Europe: The shoreline seen by the Menez-Dregan dwellers. Environ.Archaeol. 22, 28-39.

Lisiecki, L. E., Raymo, M. E., 2005. A Pliocene-Pleistocene stack of 57 globally distributed benthic $\delta 180$ records. Palaeoceanography 20 , PA1003.

Lycett, S.L., von Cramon-Taubadel, N., 2013. A 3D morphometric analysis of surface geometry in Levallois cores: Patterns of stability and variability across regions and their implications. J. Archaeol. Sci. 40, 1508-1517.

MacDonald K., Scherjon F., van Veen, E., Vaesen, K., Roebroeks, W., 2021. Middle Pleistocene fire use: The first signal of widespread cultural diffusion in human evolution. Proc. Natl. Acad. Sci. USA 118, e2101108118.

Mathias, C., Bourguignon, L., Brenet, M., Grégoire, S., Moncel, M.-H., 2020. Between new and inherited technical behaviours: A case study from the Early Middle Palaeolithic of Southern France. Archaeol. Anthropol. Sci. 12, 146.

McNabb, J., Cole, J., Hoggard, C.S., 2018. From side to side: Symmetry in handaxes in the British Lower and Middle Palaeolithic. J. Archaeol. Sci. Rep. 17, 293-310.

Mercier, N., Froget, L., Miallier, D., Pilleyre, T., Sanzelle, S., Tribolo, C., 2004. Nouvelles données chronologiques pour le site de Menez-Dregan 1 (Bretagne) : L'apport de la thermoluminescence. Quaternaire 15, 253-261.

Meyer, M., Fu, Q., Aximu-Petri, A., Glocke, I., Nickel, B., Arsuaga, J.-L., Martínez, I., Gracia, A., Bermúdez de Castro, J. M., Carbonell, E., 2014. A mitochondrial genome sequence of a hominin from Sima de los Huesos. Nature 505, 403-406. 
Milks, A., Parker, D., Pope, M., 2019. External ballistics of Pleistocene hand-thrown spears: Experimental performance data and implications for human evolution. Sci. Rep. 9, 820.

Moigne A.-M., Auguste P., Valensi P., Solano J G., Tuffreau A., Lamotte A., Barroso C., Moncel M.-H., 2016. Bone retouchers from Lower Palaeolithic sites. A focus on Terra Amata, Orgnac 3, Cagny-l'Epinette and Cueva del Angel. Quat. Int. 409, 195-212.

Moncel, M.-H., Moigne, A.-M., Sam, Y., Combier, J., 2011. The emergence of Neanderthal technical behavior: New evidence from Orgnac 3 (level 1, MIS 8), southeastern France. Curr. Anthropol. 52, 57-75.

Moncel, M.-H., Moigne, A-M., Combier, J., 2012. Towards the Middle Paleolithic in Western Europe: The case of Orgnac 3 (South-Eastern France). J. Hum. Evol. 63, 653-666.

Moncel, M.-H., Despriée, J., Voinchet, P., Tissoux, H., Moreno, D., Bahain, J-J., Courcimault, G., Falguères, C., 2013. Early evidence of Acheulean settlement in northwestern Europe - la Noira site, a 700000 year-old occupation in the Center of France, Plos One 8, e75529.

Moncel, M.-H., Ashton, N., Lamotte, A., Tuffreau, A., Cliquet, D., Despriée, J., 2015. The North-west Europe early Acheulian. J. Anthropol. Archaeol. 40, 302-331.

Moncel, M.-H., Arzarello, M., Peretto, C., 2016a. Editorial. The Holsteinian Eldorado. Quat. Int. 409, 1-8.

Moncel, M.H., Despriée, J., Voinchet, P., Courcimault, G., Hardy, B., Bahain, J.J., Puaud, S., Gallet, X., 2016b. The Acheulean workshop of la Noira (France, $700 \mathrm{ka}$ ) in the European technological context. Quat. Int. 393, 112-136.

Moncel, M.-H., Arzarello, M., Boëda, E., Bonilauri, S., Chevrier, B., Gaillard, C., Forestier, H., Yinghua Li, Sémah, F., Zeitoun, V., 2018a. The assemblages with bifacial tools in Eurasia (first part). What is going on in the West? Data on Western and Southern Europe and the Levant, C.R. Palevol 17, 1-2, 45-60.

Moncel, M.-H., Landais, A., Lebreton, V., Combourieu-Nebout, N., Nomade, S., Bazin, L., 2018b. Linking environmental changes with human occupations between 900 and $400 \mathrm{ka}$ in Western Europe, Quat. Int. 480, 78-94.

Moncel, M.-H., Santagata, C., Pereira, A., Nomade, S., Voinchet, P., Bahain, J-J., Daujeard, C., Curci, A. Lemorini, C., Hardy, B., Eramo, G., Berto, C., Raynal, J-P., Arzarello, M., Mecozzi, B., lannucci, A., Sardella, R., Allegretta, I., Delluniversità, E., Terzano, R., Dugas, P., Jouanic, G., Queffelec, A., d'Andrea, A., Valentini, R., Minucci, E., Carpentiero, L., Piperno, M., 2020a. The origin of early Acheulean expansion in Europe 700 ka ago: New findings at Notarchirico (Italy). Sci. Rep. 10, 13802.

Moncel, M-H., Ashton, N., Arzarello, M., Fontana, F., Lamotte, A., Scott, B., Muttillo, B., Berruti, B., Nenzioni, G., Tuffreau, A., Peretto, C., 2020b. Early Levallois core technology between MIS 12 and 9 in Western Europe. J. Hum. Evol. 139, 102735.

Moncel, M.-H., Despriée, J., Courcimaut, G., Voinchet, P., Bahain, J-J., 2020c. La Noira site (Centre, France) and the technological behaviours and skills of the earliest Acheulean in Western Europe between 700 and 600 kyrs. J. Paleolit. Archeol. 3, 255-301.

Moncel, M.-H., Biddittu, I., Manzi, G., Saracino, B., Pereira, A., Nomade, S., Hertler, C., Voinchet, P., Bahain, J.-J.,2020d. Emergence of regional cultural traditions during the Lower Paleolithic: evidence of a network of sites at the MIS 11-10 transition in Central Italy (Frosinone-Ceprano basin). Archaeol. Anthropol. Sci. 12, 185.

Moncel, M.-H., Garcia Medrano, P., Despriée, J., Arnaud, J., Voinchet, P., Bahain J-J, 2021. Tracking behavioral persistence and innovations during the Middle Pleistocene in Western Europe. Shift in occupations between $700 \mathrm{ka}$ and $450 \mathrm{ka}$ at la Noira site (Centre, France). J. of Hum. Evol. 156, 103009.

Monnier, J.-L., 1996. Acheuléen et industries archaïques dans le Nord-Ouest de la France. In: Tuffreau A. (Ed.), L'Acheuléen dans l'Ouest de l'Europe: Actes du Colloque de SaintRiquier, 6-10 juin 1989. Publications du CERP, Num. 4, Université des Sciences et Technologies de Lille, Villeneuve-d'Ascq, pp. 145-153. 
Monnier, J.-L., Le Cloirec, R., 1985. Le gisement Paléolithique inférieur de la Pointe de Saint-Colomban à Carnac (Morbihan). Gallia Préhistoire 28, 7-36.

Monnier, J.-L., Hallégouët, B., Hinguant, S., Laurent, M., Auguste, P., Bahain, J.-J., Falguères, C., Gebhardt, A., Marguerie, D., Molines, N., Morzadec, H., Yokoyama, Y., 1994. A new regional group of the Lower Palaeolithic in Brittany (France), recently dated by Electron Spin Resonance. C.R. Acad. Sci. 319, 155-160.

Monnier, J.-L., Hallégouët, B., Hinguant, S., Molines, N., 1996a. Rapport de fin d'opération pluriannuelle sur la fouille du gisement Paléolithique inférieur de Menez-Dregan I (Plouhinec, Finistère), UMR 153 du CNRS, t. 1, Rennes.

Monnier, J.-L., Hallégouët, B., Hinguant, S., Molines, N., 1996b. Rapport de fin d'opération pluriannuelle sur la fouille du gisement Paléolithique inférieur de Menez-Dregan I (Plouhinec, Finistère), UMR 153 du CNRS, t. 2, Rennes.

Monnier, J.-L., Hallégouët, B., Hinguant, S., Molines, N., 2001. La datation de l'habitat Paléolithique de Menez-Dregan I (Plouhinec, Finistère, France). Argumentation géologique et archéologique. In: Barrandon J.-N., Guibert P., Michel V. (dir.), Datation, XXle Rencontres Internationales d'Archéologie et d'Histoire d'Antibes, éd. APDCA, Antibes, pp. 261-277.

Monnier, J.-L., Tsobgou-Ahoupe, R., Ravon, A.-L., Hallégouët, B., Laforge, M., Marguerie, D., Van Vliet-Lanoë, B., Bouchet, F., Le Bailly, M., Falguères, C., Bahain, J.-J., Mercier, N., 2009. Plouhinec (Finistère), Le gisement Paléolithique inférieur de MenezDregan I. Rapport intermédiaire de fouille programmée. CNRS-UMR $6566 \mathrm{CReAAH}$, Université de Rennes 1, Ministère de la Culture et de la Communication, Conseil Général du Finistère, Mairie de Plouhinec.

Monnier, J.-L., Ravon, A.-L., Hinguant, S., Hallégouët, B., Gaillard, C., Laforge, M., 2016a. Menez-Dregan (Plouhinec, Finistère, France): Un site d'habitat du Paléolithique inférieur en grotte marine. Stratigraphie, structures de combustion, industries riches en galets aménagés. L'Anthropologie 120, 237-262.

Monnier, J.-L., Lefort, J.-P., Cliquet, D., Hinguant, S., Huet, B., Pigeaud, R., Ravon, A.-L., 2016b. Des mammouths et des hommes en Armorique. Occupations humaines et variations de l'environnement au Pléistocène dans l'Ouest de la France. Bull. Mus. Anthropol. Préhist. Monaco, suppl. n 6, 91-121.

Mosquera, M., Ollé, A., Rodríguez, X.P., 2013. From Atapuerca to Europe: Tracing back the earliest peopling of Europe. Quat. Int. 295, 130-137.

Mourre, V., Jarry, M., 2009. “Entre le marteau et l'enclume”...Table-ronde sur la percussion directe au percuteur dur et la diversité de ses modalités d'application. PALEO Numéro spécial 1.

Ollé, A., Mosquera, M., Rodríguez-Álvarez, X. P., García-Medrano, P., Barsky, D., de Lombera-Hermida, A., Carbonell, E., 2016. The Acheulean from Atapuerca: Three steps forward, one step back. Quat. Int. 411, 316-328.

Parfitt, S.A., Ashton, N.M., Lewis, S.G., Richard, A.L., Coope, G.R., Field, M.H., Gale, R., Hoare, P.G., Larkin, N.R., Lewis, M.D., Karloukovski, V., Maher, B.A., Peglar, S.M., Preece, R.C., Whittaker, J.E., Stringer, C.B., 2010. Early Pleistocene human occupation at the edge of the boreal zone in northwest Europe. Nature 466, 229-233.

Peretto, C., Arzarello, M., Bahain, J.-J., Boulbes, N., Dolo, J.-M., Douville, E., Falguères, C., Frank, N., Garcia, T., Lembo, G., Moigne, A.-M., Muttillo, B., Nomade, S., Pereira, A., Rufo, M.A., Sala, B., Shao, Q., Hohenstein, U.T., Tessari, U., Turrini, M.C., Vaccaro, C., 2016. The Middle Pleistocene site of Guado San Nicola (Monteroduni, Central Italy) on the Lower/ Middle Palaeolithic transition. Quat. Int. 411B, 301-315.

Ravon, A.-L., 2017a. Originalité et développement du Paléolithique inférieur à l'extrémité occidentale de l'Eurasie : le "Colombanien" de Menez-Dregan (Plouhinec, Finistère, Bretagne). PhD Dissertation, Université Rennes 1.

Ravon, A.-L., 2017b. 1988-2018: 30 ans de fouilles à Menez-Dregan I (Plouhinec, Finistère). Bull. l'AMARAI 30, 35-52. 
Ravon, A.-L., 2019. Early human occupations at the Westernmost tip of Eurasia: The lithic industries from Menez-Dregan I (Plouhinec, Finistère, France), C.R. Palevol 18, 663-684.

Ravon, A.-L., Laforge, M., 2019. Du Paléolithique inférieur au Paléolithique moyen ancien à l'ouest de la péninsule armoricaine : Une revue des occupations saaliennes de Bretagne. In: Montoya, C., Fagnart, J.P., Locht, J.-L. (Eds.), Préhistoire de l'Europe du Nord-Ouest: Mobilités, climats et entités culturelles. XXVIIle Congrès Préhistorique de France. Amiens, 30 mai-4 juin 2016, vol. 1, 201-214.

Ravon, A.-L., Monnier, J.-L., 2013. La transition Paléolithique inférieur-moyen dans l'Ouest armoricain : L'exemple de la couche 4 du site de Menez-Dregan I (Plouhinec, Finistère). Bull. Soc. Préhist. Française 110, 7-23.

Ravon, A.-L., Monnier, J.-L., Laforge, M., 2016a. Menez-Dregan, layer 4: A transitional layer between the Lower and Middle Palaeolithic in Brittany. Quat. Int. 409, 92-103.

Ravon, A.-L., Gaillard, C., Monnier, J.-L., 2016b. Menez-Dregan (Plouhinec, Far Western Europe): The lithic industry from layer 7 and its Acheulian components. Quat. Int. 411, 132-143.

Ravon, A.-L., Gallou, C., García-Medrano, P., Bernard, Y., Guégan, S., Laforge, M., Le Goff, E., Sylvain, A., Gaillard, C., Hinguant, S., Monnier, J.-L., 2019. Plouhinec (Finistère), Menez-Dregan I, Des Prénéandertaliens aux Néandertaliens, les premières occupations paléolithiques, rapport de fouille programmée. CNRS-UMR $6566 \mathrm{CReAAH}$, Université de Rennes 1, Ministère de la Culture et de la Communication, Conseil Départemental du Finistère, Mairie de Plouhinec.

Ravon, A.-L., García-Medrano, P., Bernard, Y., Guégan, S., Laforge, M., Le Goff, E., Sylvain, A., Gaillard, C., Hinguant, S., Monnier, J.-L., 2020. Plouhinec (Finistère), MenezDregan I, Des Prénéandertaliens aux Néandertaliens, les premières occupations paléolithiques, rapport de fouille programmée 2020 et triennal 2018-2020, CNRS-UMR 6566 $\mathrm{CReAAH}$, Université de Rennes 1, Ministère de la Culture et de la Communication, Conseil Départemental du Finistère, Mairie de Plouhinec.

Roberts, M.B., Parfitt, S.A., 1999. Boxgrove. A Middle Pleistocene Hominid Site at Eartham Quarry, Boxgrove, West Sussex. English Heritage, London.

Rodríguez, J., Burjachs, F., Cuenca-Bescós, G., García, N., Made van der, J.., PérezGonzález, A., Pérez González, A., Blain, H.A., Expósito, I., López-García, J.M., García Antón, M., Allué, E., Cáceres, I., Huguet, R. Mosquera, M., Ollé, A., Rosell, J., Parés, J.M., Rodríguez, X.P., Carbonell, E., 2011. One million years of cultural evolution in a stable environment at Atapuerca (Burgos, Spain). Quat. Sci. Rev. 30, 1396-1412.

Rodríguez-Hidalgo, A., Saladié, P., Ollé, A., Carbonell, E., 2015. Hominin subsistence and site function of TD10.1 bone bed level at Gran Dolina site (Atapuerca) during the late Acheulean. J. Quat. Sci. 30, 679-701.

Rodríguez-Hidalgo, A., Saladie, P., Ollé, A., Arsuaga, J. L., de Castro, J. M. B., Carbonell, E., 2017. Human predatory behavior and the social implications of communal hunting based on evidence from the TD10. 2 bison bone bed at Gran Dolina (Atapuerca, Spain). J. Hum. Evol. 105, 89-122.

Roe, D. A., 1964. The British Lower and Middle Palaeolithic: Some problems, methods of study and preliminary results. Proc. Prehist. Soc. 30, 245-267.

Roe, D. A. (1968). British Lower and Middle Palaeolithic handaxe groups. Proc. Prehist. Soc. $34,1-82$.

Roebroeks, J.W.M., 2001. Hominin behaviour and the earliest occupation of Europe: An exploration. J. Hum. Evol. 41,437-461.

Roebroeks, J.W.M., 2006. The human colonisation of Europe: Where are we? J. Quat. Sci. 21, 425-436.

Roebroeks, J.W.M., van Kolfschoten, T., 1995. The earliest occupation of Europe.

Proceedings of the European Science Foundation workshop at Tautavel (France), 1993.

University of Leiden, Leiden. 
Roebroeks, W., Villa, P., 2011. On the earliest evidence for habitual use of fire in Europe. Proc. Natl. Acad. Sci. USA 108, 5209-5214.

Rossoni-Notter, E., Notter, O., Simone, S., Simon, P., 2016. Acheulean technical behaviors in Aldène cave (Cesseras, Hérault, France). Quat. Int. 409, 149-176.

Santonja, M., Rubio-Jara, S., Panera, J., Sánchez-Romero, L., Tarriño, A, Pérez-González, A., 2018. Ambrona revisited: The Acheulean lithic industry in the lower stratigraphic complex. Quat. Int. 480, 95-117.

Sanz, M., Daura, J., Cabanes, D., Égüez, N., Carrancho, A., Badal, E., Souto, P., Rodrigues, F., Zilhão, J., 2020. Early evidence of fire in south-western Europe: The Acheulean site of Gruta da Aroeira (Torres Novas, Portugal). Sci. Rep. 10, 12053.

Santucci, E., Marano, F., Cerilli, E., Fiore, I., Lemorini, C., Palombo, M. R., Anzidei, A.P., Bulgarelli, G. M., 2016. Palaeoloxodon exploitation at the middle Pleistocene site of La Polledrara di Cecanibbio (Rome, Italy). Quat. Int. 406, 169-182.

Schoch, W.H., Bigga, G., Böhner, U., Richter, P., Terberger, T., 2015. New insights on the wooden weapons from the Paleolithic site of Schöningen. J. Hum. Evol. 89, 214-225.

Scott, B., 2011. Becoming Neanderthals. The Earlier British Middle Palaeolithic. Oxbow Books, Oxford.

Scott, B., Ashton, N., 2011. The Early Middle Palaeolithic: The European Context. In: Ashton, N., Lewis, S.G., Stringer, C. (Eds.), The Ancient Human Occupation of Britain. Elsevier, Amsterdam, pp. 67-89.

Shackleton, N. J., 1987. Oxygen isotopes, ice volume and sea level. Quat. Sci. Rev. 6, 183-190.

Sharon, G. 2009. Acheulian giant-core technology: A worldwide perspective. Curr. Anthropol. 50, 335-367.

Sharon, G., Barsky, D., 2016. The emergence of the Acheulian in Europe-A look from the east. Quat. Int. 411, 25-33.

Shipton, C., Clarkson, C., Pal, J. N., Jones, S. C., Roberts, R. G., Harris, C., Gupta, M.C., Ditchfield, P.W., Petraglia, M.D., 2013. Generativity, hierarchical action and recursion in the technology of the Acheulean to middle Palaeolithic transition: A perspective from Patpara, the Son Valley, India. J. Hum. Evol. 65, 93-108.

Shipton, C., Clarkson, C., 2015a. Flake scar density and handaxe reduction intensity. J. Archaeol. Sci. Rep. 2, 169-175.

Shipton, C., Clarkson, C., 2015b. Handaxe reduction and its influence on shape: An experimental test and archaeological case study. J. Archaeol. Sci. Rep. 3, 408-419.

Shipton, C. White, M., 2020. Handaxe types, colonization waves, and social norms in the British Acheulean. J. Archaeol. Sci. Rep. 31, 102352.

Shott, M.J., 1999. On bipolar reduction and splintyered pieces. North Am. Archaeol. 20, 217238.

Stiner, M.C., Barkai, R., Gopher, A., 2009. Cooperative hunting and meat sharing 400-200 kya at Qesem Cave, Israel. Proc. Nat. Acad. Sci. USA 106, 13207-13212.

Stringer C., 2012. The status of Homo heidelbergensis (Schoetensack 1908). Evol. Anthropol. 21, 101-107.

Thieme, H., 1997. Lower Paleolithic hunting spears from Germany. Nature 385, 807-810.

Tixier, J., Inizan, M.-L., Roche, H., 1980. Préhistoire de la pierre taillée - t.1 : terminologie et technologie. Cercle de Recherches et d'Études Préhistoriques, Antibes.

Turq, A., Roebroeks, W., Bourguignon, L., Faivre, J.-P., 2013. The fragmented character of Middle Palaeolithic stone tool technology. J. Hum. Evol. 65, 641-655.

Vallverdú, J., Saladié, P., Rosas, A., Huguet, R., Cáceres, I., Mosquera, M., GarciaTabernero, A., Estalrrich, A., Lozano-Fernández, I., Pineda-Alcalá, A., Villalaín, J.J., Bourlès, 
D., Braucher, R., Lebatard, A., Vilalta, J., Esteban-Nadal, M., Lluc Bennàsar, M., Bastir, M., López-Polín, L., Ollé, A., Vergé, J.M., Ros-Montoya, S., Martínez-Navarro, B., García, A., Martinell, J., Expósito, I., Burjachs, F., Agustí, J., Carbonell, E., 2014. Age and date for early arrival of the Acheulian in Europe (Barranc de la Boella, la Canonja, Spain). Plos One 9, e103634.

van Kolfschoten, T., Parfitt, S.A., Serangeli, J., Bello, S.M., 2015. Lower Paleolithic bone tools from the 'Spear Horizon' at Schöningen (Germany). J. Hum. Evol. 89, 226-263.

Vergès, J.M., Ollé, A., 2011. Technical microwear and residues in identifying bipolar knapping on an anvil: Experimental data. J. Archaeol. Sci. 38, 1016-1025.

Viallet, C. 2016. Bifaces used for percussion? Experimental approach to percussion marks and functional analysis of the bifaces from Terra Amata (Nice, France). Quat. Int. 409, 174181.

Villa, P., 1981. Matières premières et provinces culturelles dans l'Acheuléen français.

Quaternaria 23, 19-35.

Voinchet, P., Moreno, D., Bahain, J.-J., Tissoux, H., Tombret, O., Falguères, C., Moncel, M.H., Schreve, D., Candy, I., Antoine, P., Ashton, N., Beamish, M., Cliquet, D., Despriée, J., Lewis, S., Limondin-Lozouet, N., Locht, J.-L., Parfitt, S., Pope, M., 2015. Chronological data (ESR and ESR/U-series) for the earliest Acheulean sites of northwestern Europe. J. Quat. Sci. 30, 610-623.

Voormolen, B., 2008. Ancient hunters, modern butchers. Schöningen 13II-4, a kill-butchery site dating from the northwest European Lower Palaeolithic. Ph.D. Dissertation, University of Leiden.

Waelbroeck, C., Labeyrie, L., Michel, E., Duplessy, J.C., McManus, J.F., Lambeck, K., Balbon, E., Labracherie, M., 2002. Sea-level and deep water temperature changes derived from benthic foraminifera isotopic records. Quat. Sci. Rev. 21, 295-305.

Warren, S.H., 1911. A piece of worked wood, possibly the point of a Palaeolithic spear. Quart. J. Geol. Soc. Lond. 67, 119.

White, M. J., 1998. Twisted ovate bifaces in the British Lower Palaeolithic: Some observations and implications. In: Ashton, N. M., Healy, F., Pettitt, P. B. (Eds.), Stone Age Archaeology: Essays in Honour of John Wymer. Oxbow Books, Lithic Studies Occasional Paper 6, Oxford, pp. 98-104.

White, M., Ashton, N., 2003. Lower Palaeolithic core technology and the origins of the Levallois method in north-western Europe. Curr. Anthropol. 44, 598-609.

Wiśniewski, A., 2014. The beginnings and diversity of Levallois methods in the early Middle Palaeolithic of Central Europe. Quat. Int. 326-327, 364-380.

Yokoyama, Y., Falguères, C., Bahain, J.-J., Ajaja, O., Laurent, M., Michel, V., Masaoudi, H., Saleki, H., Rousseau, L., 1998. Géochronologie de quelques sites français du Pléistocène moyen et supérieur XIII Congrès UISPP, Forli, vol. 1, pp. 327-336.

Zutovski, K., Barkai, R., 2016. The use of elephant bones for making Acheulian handaxes: A fresh look at old bones. Quat. Int. 406, 227-238. 


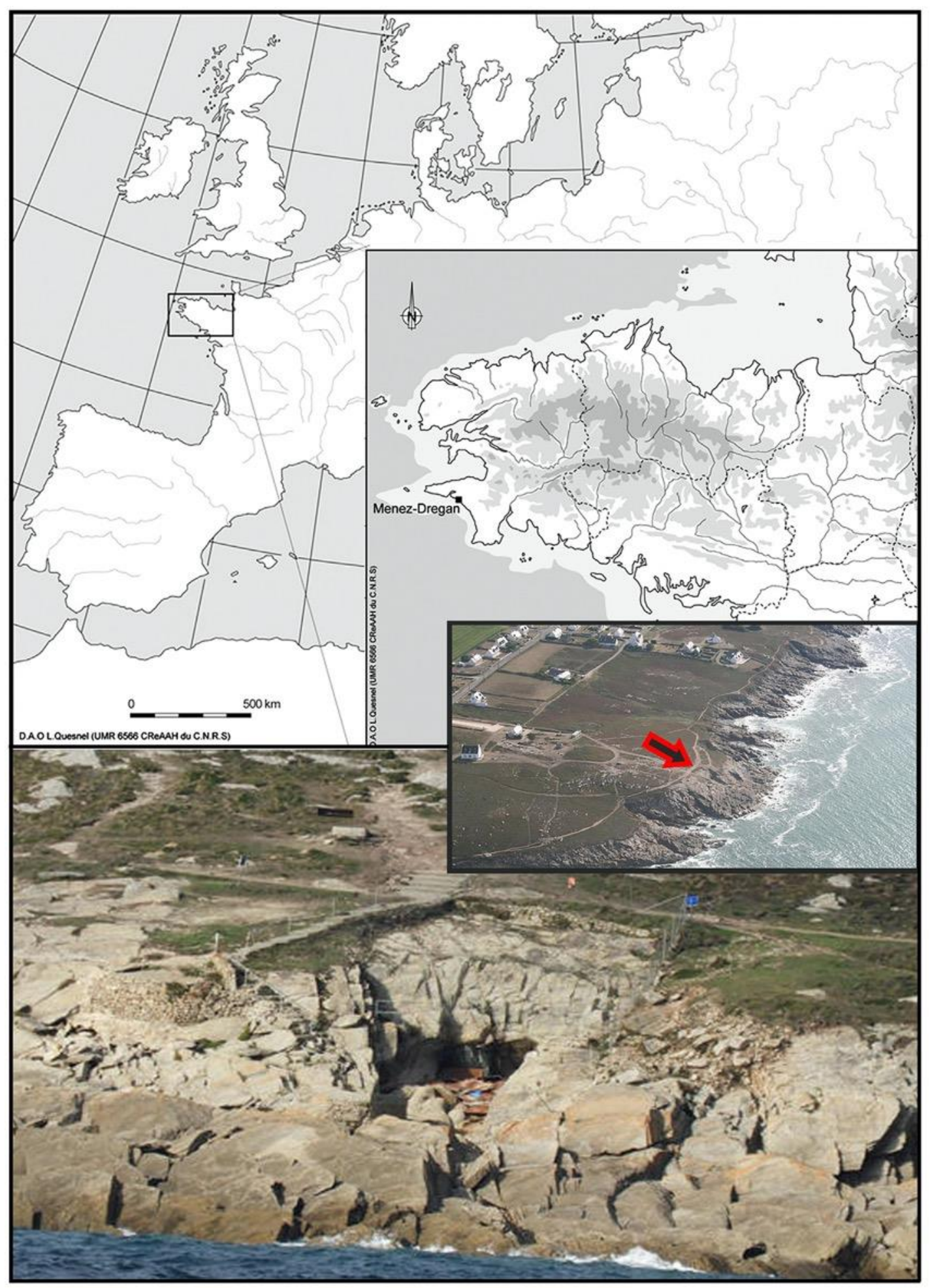

Figure 1. Location of Menez-Dregan I (Maps: L. Quesnel and A.L. Ravon; photos: C. Martin and S. Rémy). 


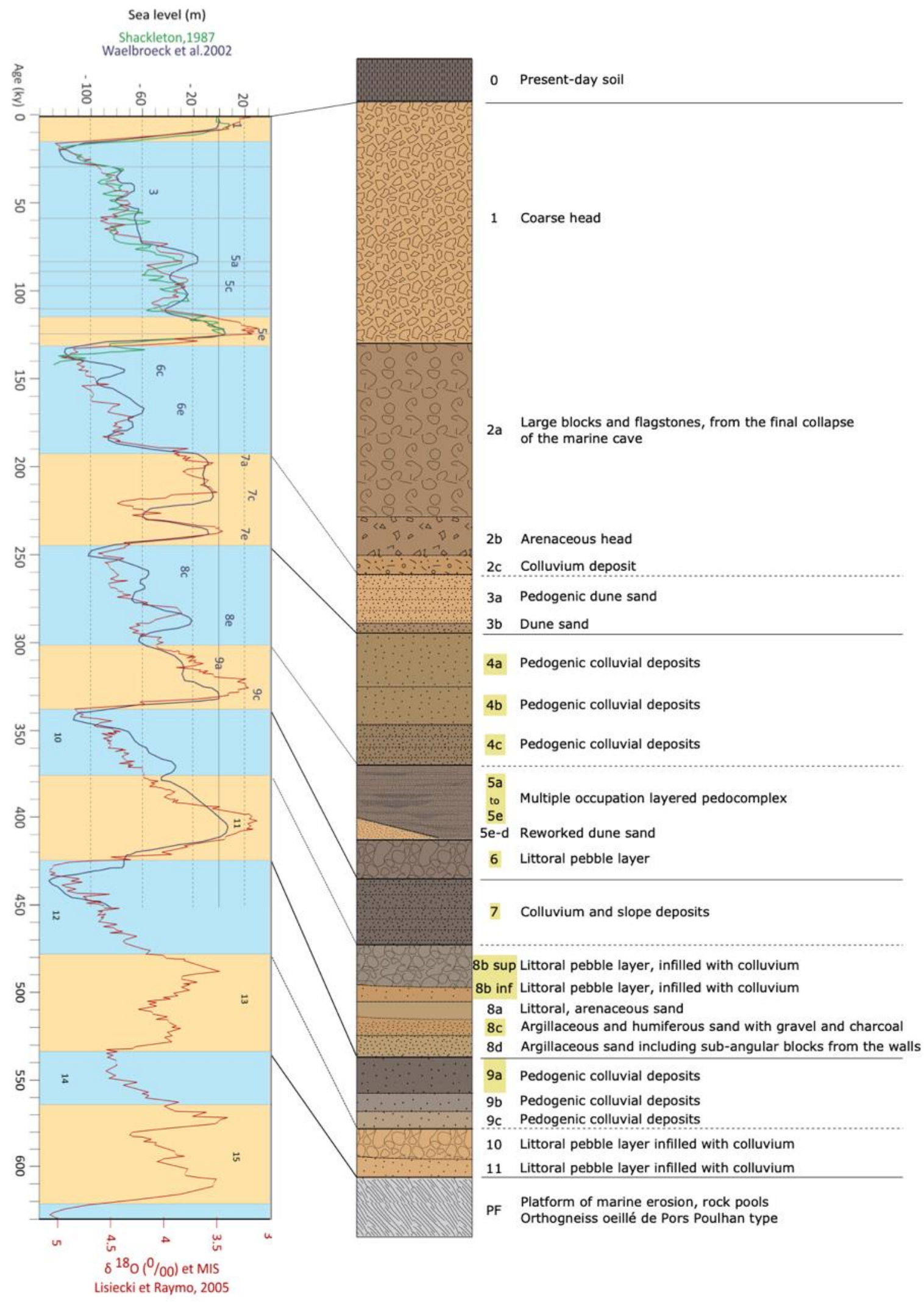

Figure 2. Synthetic stratigraphic log and chronostratigraphic interpretation of the site of Menez-Dregan I. Calibration of sea level variation curves based on the work of Waelbroeck et al. (2002), Shackleton (1987), Lisiecki and Raymo (2005), and Laforge (2012). The levels of human occupation are highlighted in yellow. 0: present-day soil; 1: coarse head; 2a: large blocks and flagstones, from the final collapse of the marine cave; $2 \mathrm{~b}$ : arenaceous head; $3 \mathrm{a}$ : pedogenic dune sand; 3b: dune sand; 4a-c: pedogenic colluvial deposits; $5 a-e:$ Multiple occupation layered pedocomplex; 5e-d: reworked dune sand; 6 : littoral pebble layer; 7 : colluvium and slope deposits, $8 \mathrm{~b}$ inf. and sup.: littoral pebble layer, infilled with colluvium; 8a: 
littoral, arenaceous sand; 8c: argillaceous and humiferous sand with gravel and charcoal; 8d: argillaceous sand including sub-angular blocks from the walls; 9a-9c: pedogenic colluvial deposits; 10-11: littoral pebble layer infilled with colluvium.
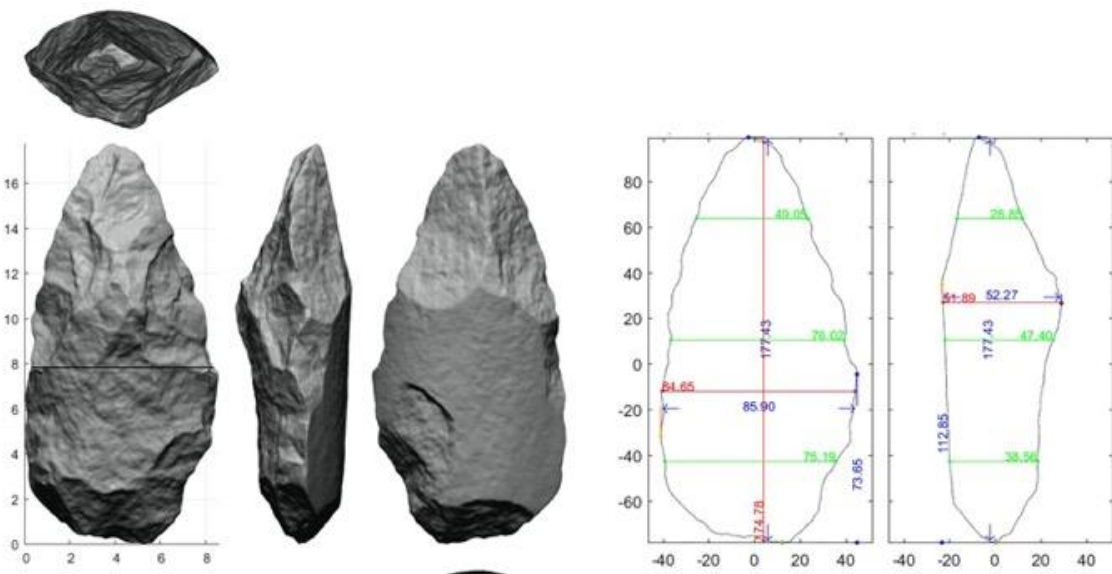

Length (L)

Maximum width $(\mathrm{m})$

Maximum Thickness (e)

Width at middle Length $(\mathrm{n})$

Base Length (a)

Distal Length (L-a)

Distal width (B1)

Proximal width (B2)

Distal Thickness (T1)

* Elongation Index $(\mathrm{L} / \mathrm{m})$

** Refinement Index (m/e)

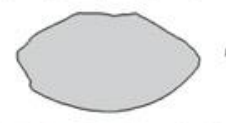

$5 \mathrm{~cm}$

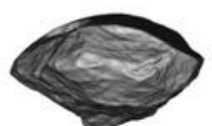

$\begin{array}{llllll}20 & 0 & 20 & 40\end{array}$
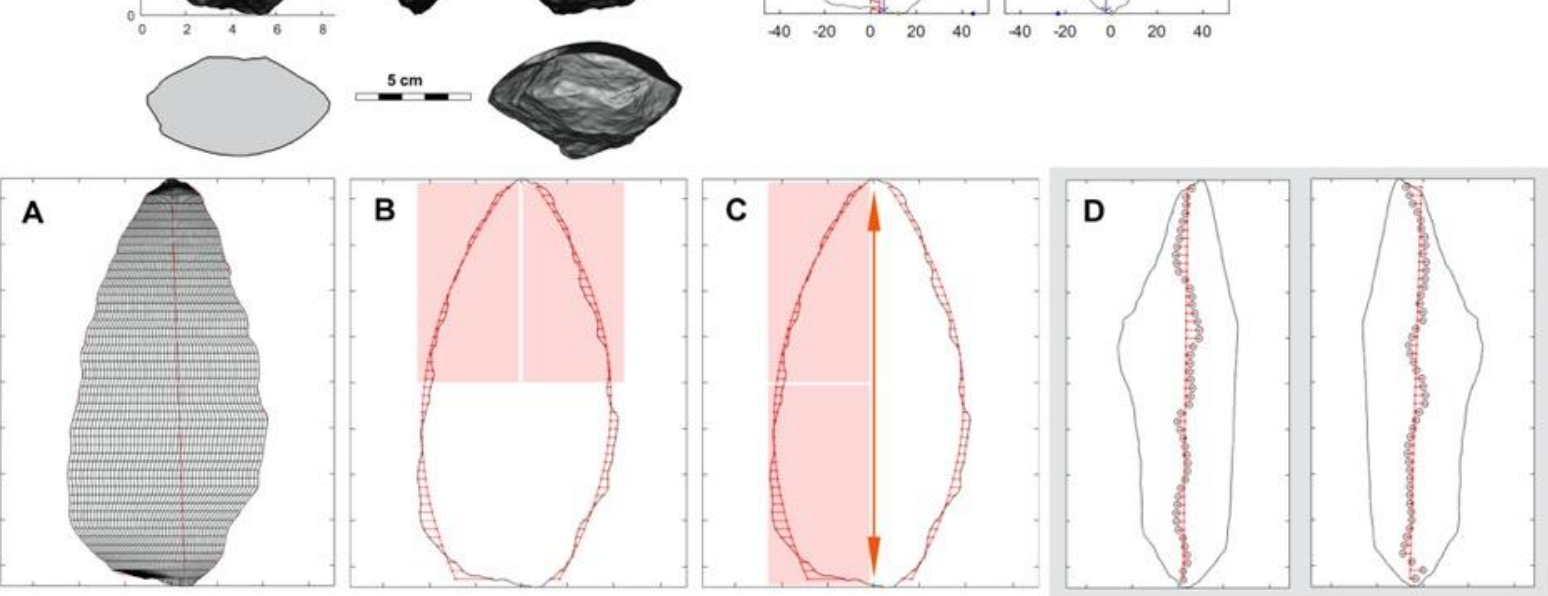

Figure 3. Example of plan, profile views and sections from a handaxe 3D model and the location of the measurements considered, extracted with Artifact 3D Software. A) 5000 points defining outlines and tool surfaces; B) edge curvature: visualization of deviation from perfect bilateral symmetry and C) from perfect bifacial symmetry; D) edge irregularity. 


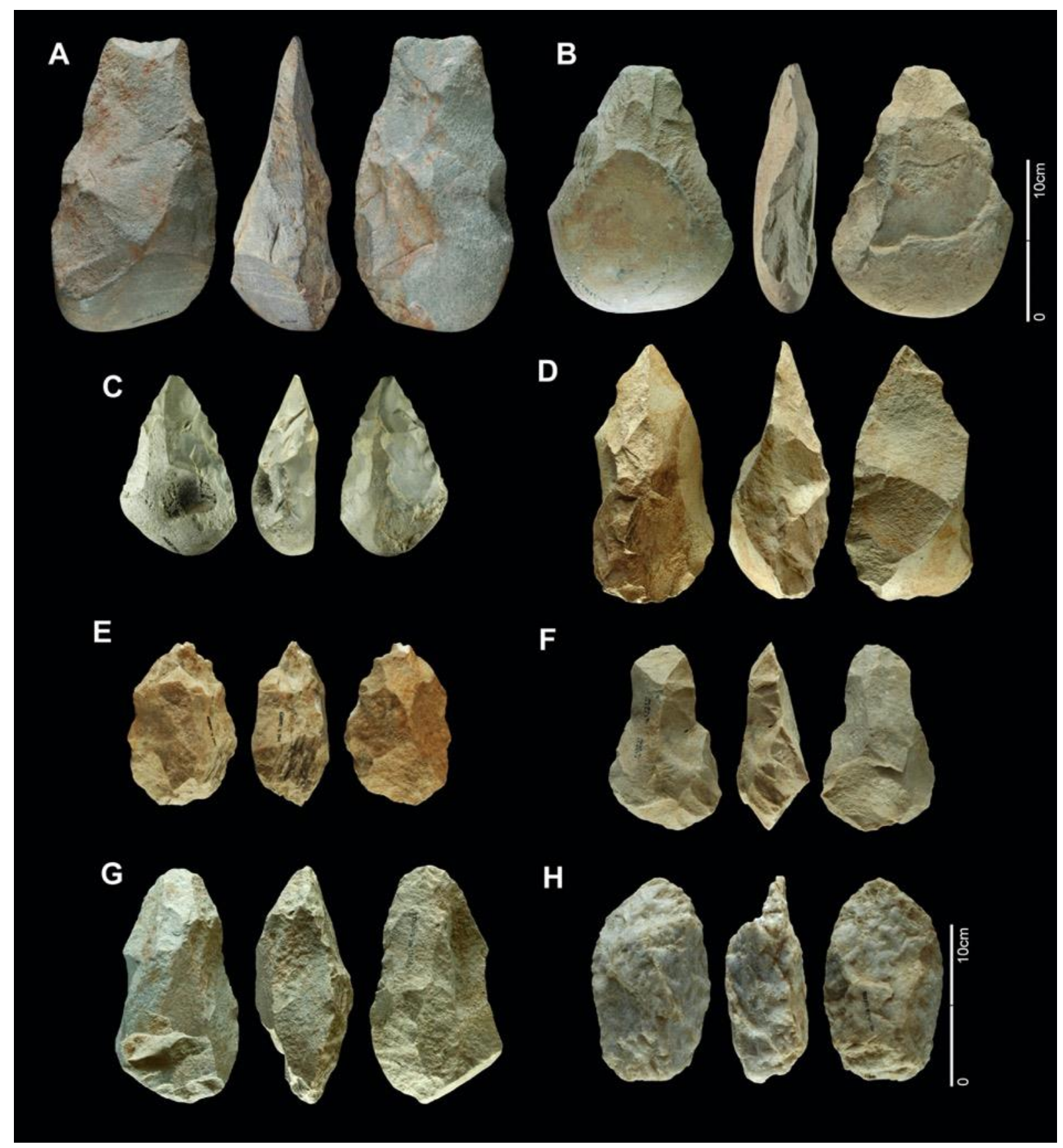

Figure 4. Handaxes from MDI on cobble: A) MDI.4b.4331; B) MDI.5b.3866; C) MDI.5a.159; D) MDI.7.115085; on unknown blanks: E) MDI.7.120899; F) MDI.7.125555; G) MDI.8b.131650; H) MDI.8b.12886. 


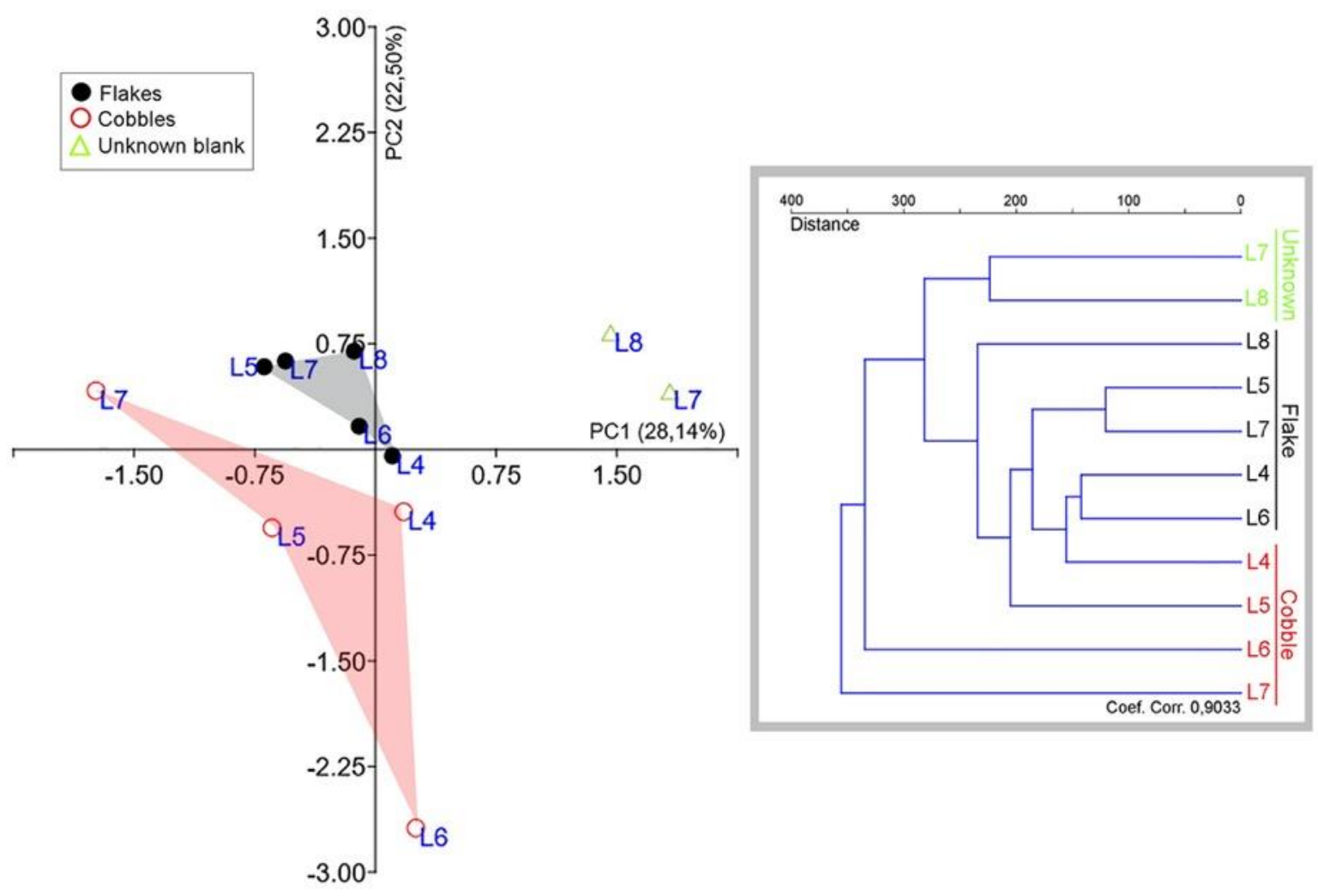

Figure 5. Principal component analysis (PCA) of the technological features considered for the analysis of handaxes and cleavers by type of blank: cobbles (red circles), flakes (black dots) and unknown blanks (green triangles). Tools analyzed as a single unit and divided in three different parts. The graphic at right: cluster analysis and distances between the groups represented in the PCA. 


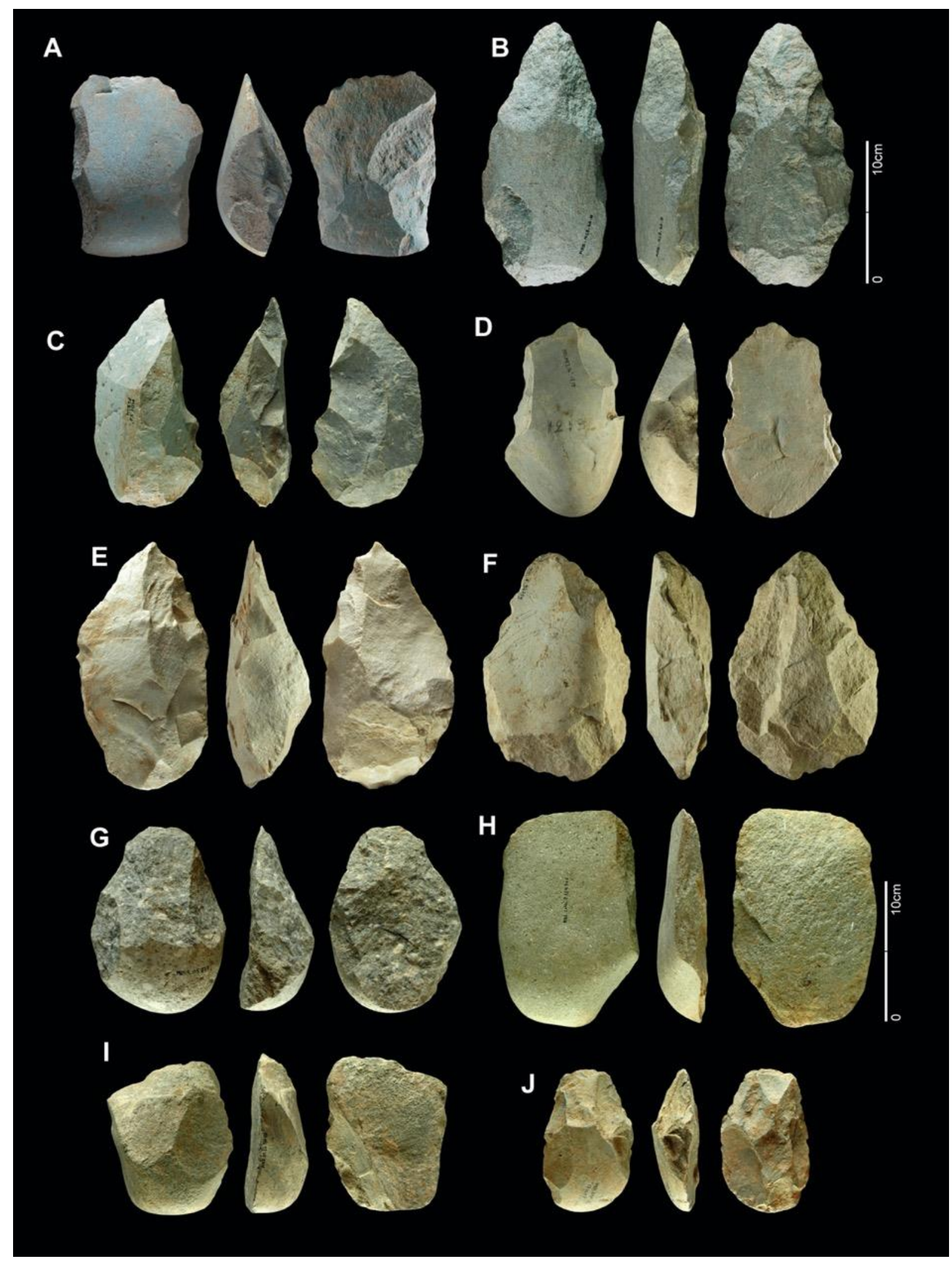

Figure 6. Handaxes and cleavers from Menez-Dregan I on flakes: A) MDI.4b.237; B) MDI.4a.11; C) MDI.5d'.72824; D) MDI.5c'.1219; E) MDI.6.71166; F) MDI.6.94759; G) MDI.7.115337; H) MDI.7.129366; I) MDI.8b.104070; J) MDI.8b.131407. 


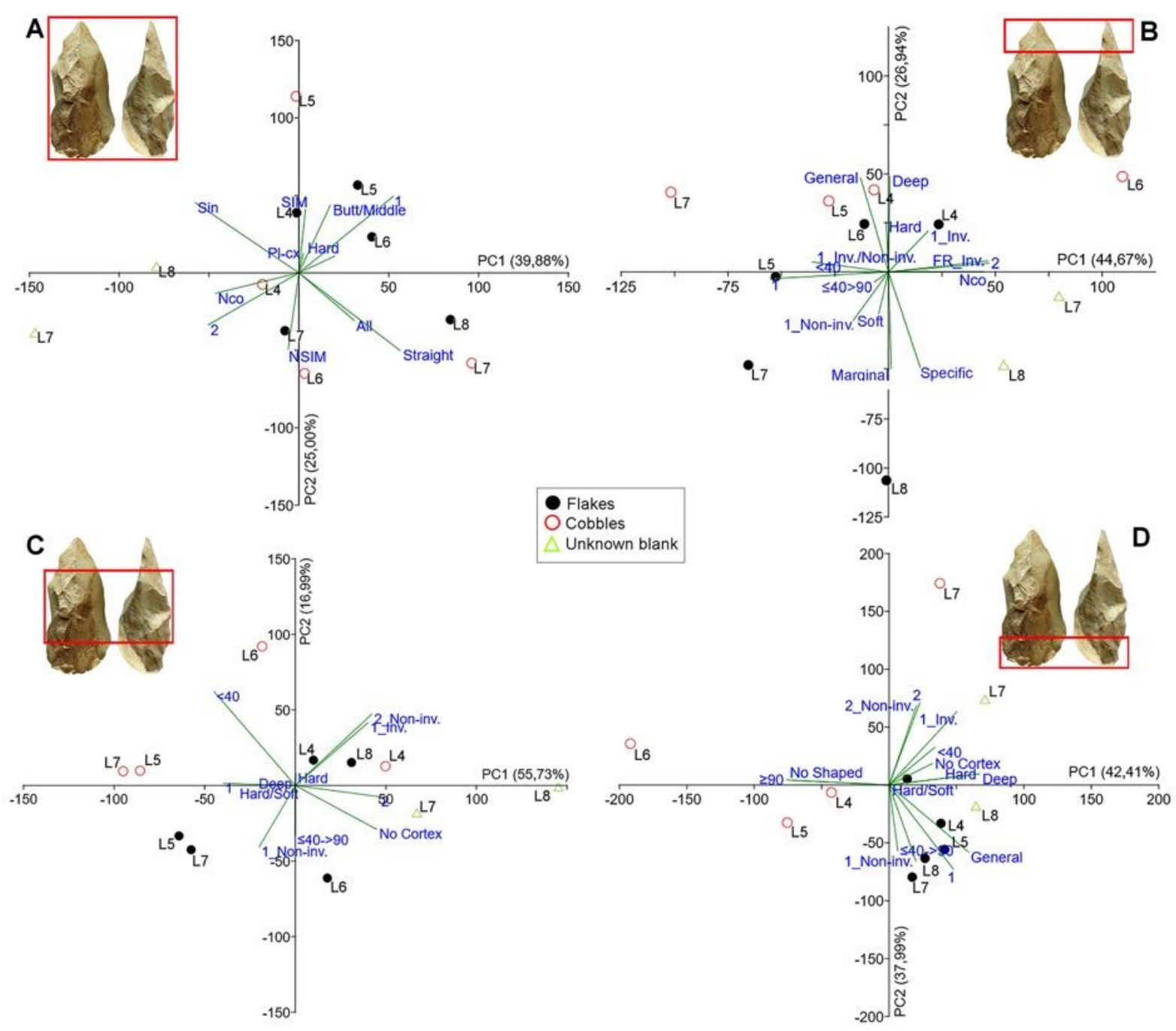

Figure 7. Plots of principal component analyses (PC1 vs. PC2) of the technological features which have a major effect on each group: cobbles (red circles), flakes (black dots) and unknown blanks (red triangles). A) general aspects; B) distal part; C) mid part; and D) proximal part, according to Table 3 . 


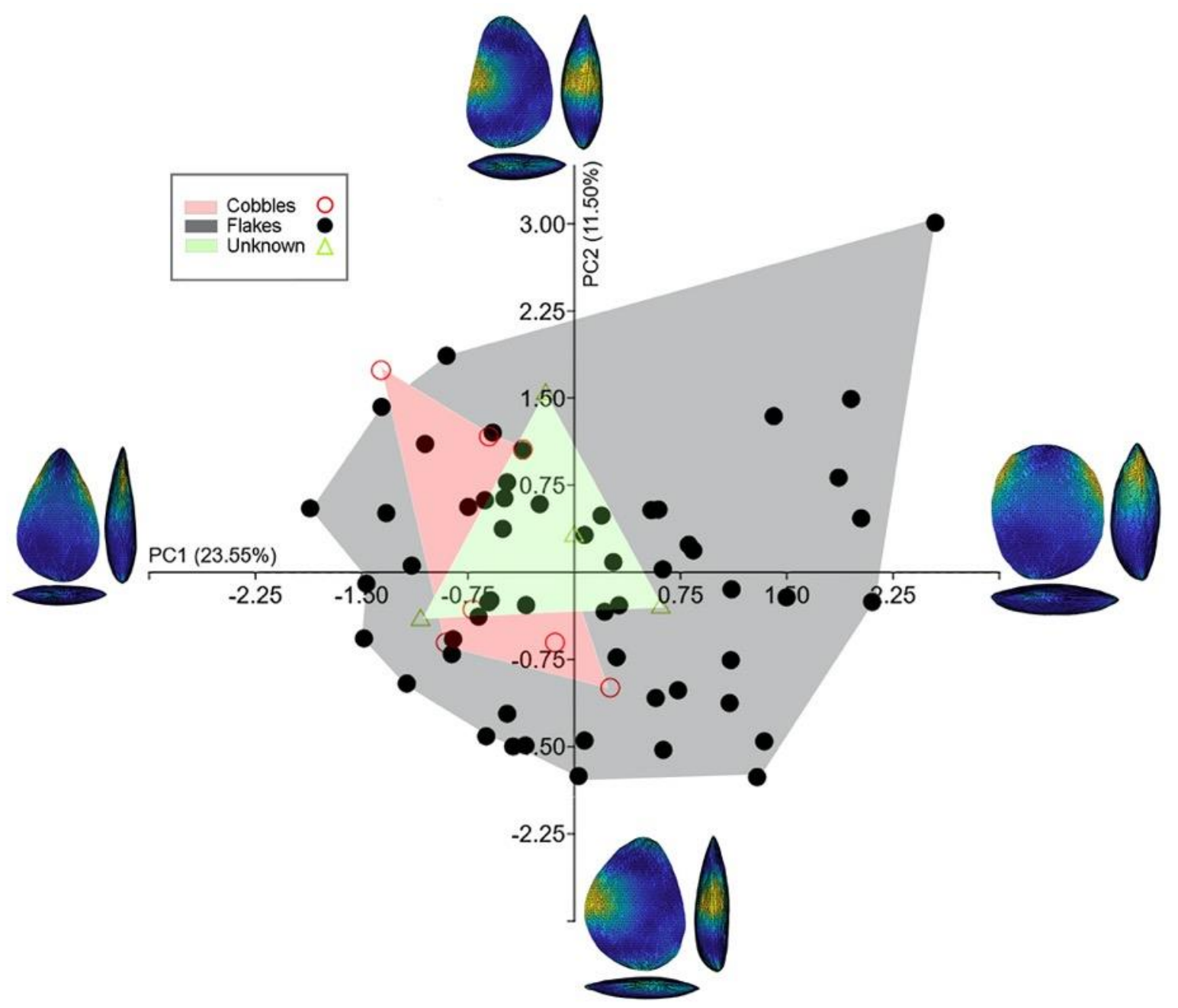

Figure 8. Plots of principal component analyses of handaxes and cleavers morphometry from MDI by type of blanks: cobbles (red circles), flakes (blank dots) and unknown blanks (green triangles). The geometric morphometric analysis has been done using 3D models composed of 5000 semi-landmarks. Convex hulls indicate the range of points for a given group, and the warps' tool represent the morphology. Color coding represents the landmarks that vary the most on the shape trend described on positive and negatives scores of PC1 and PC2 (from blue, less variability to yellow, highest variability). 
Table 1

Composition of the lithic assemblage and chronostratigraphic attribution (MIS) of Menez-Dregan I. In this table, stratigraphic units (SU) 4 and 5 consist of a mix of reworked different archaeological levels and do not correspond to a human occupation level. Small chips and debris are not represented in this table.

\begin{tabular}{|c|c|c|c|c|c|c|c|c|c|c|c|c|c|c|c|c|c|c|c|c|c|c|c|}
\hline MIS & \multicolumn{3}{|c|}{12} & \multicolumn{2}{|c|}{11} & \multirow{2}{*}{$\begin{array}{l}10 \\
7\end{array}$} & \multirow{2}{*}{$\begin{array}{l}9 c \\
6^{\prime}\end{array}$} & \multicolumn{10}{|c|}{$9 a$} & \multicolumn{3}{|c|}{$8 \mathrm{e}$} & 7 & \multirow[t]{2}{*}{ Total } & \multirow[t]{2}{*}{$\%$} \\
\hline \begin{tabular}{|l|} 
Tool type/SU \\
\end{tabular} & $9 a$ & $9 \mathrm{~b}$ & 9c & $8 c$ & $8 \mathrm{~b}$ & & & $5 e$ & $5 d^{\prime}$ & $5 d$ & $5 c^{\prime}$ & $5 c$ & $5 b^{\prime}$ & $5 b$ & $5 a^{\prime}$ & $5 a$ & 5 & $4 c$ & $4 a b$ & 4 & $3 a$ & & \\
\hline Flakes $<10 \mathrm{~cm}$ & 1571 & 0 & 4 & 104 & 2357 & 7994 & 11013 & 1156 & 23550 & 2409 & 6658 & 1024 & 7267 & 1012 & 8973 & 1861 & 135 & 4332 & 1621 & 157 & 1 & 83199 & $54 \%$ \\
\hline \begin{tabular}{|l} 
Flake fragments \\
\end{tabular} & 1721 & 0 & 2 & 73 & 1531 & 5100 & 5114 & 451 & 8938 & 971 & 3628 & 538 & 3587 & 526 & 3887 & 1187 & 86 & 3695 & 1567 & 95 & 0 & 42697 & $28 \%$ \\
\hline Cores & 371 & 0 & 0 & 38 & 638 & 1599 & 2618 & 349 & 5625 & 367 & 1079 & 250 & 1629 & 194 & 1164 & 403 & 51 & 819 & 445 & 44 & 1 & 17684 & $11 \%$ \\
\hline $\begin{array}{l}\text { Small retouched } \\
\text { tools }\end{array}$ & 95 & 0 & 0 & 15 & 297 & 573 & 581 & 17 & 325 & 32 & 148 & 38 & 174 & 24 & 170 & 30 & 4 & 253 & 81 & 8 & 0 & 2865 & $2 \%$ \\
\hline Choppers & 5 & 0 & 0 & 0 & 142 & 243 & 314 & 14 & 206 & 12 & 22 & 5 & 55 & 2 & 26 & 12 & 2 & 33 & 51 & 6 & 0 & 1150 & $1 \%$ \\
\hline Chopping-tools & 0 & 0 & 0 & 0 & 12 & 41 & 31 & 3 & 62 & 1 & 0 & 1 & 4 & 1 & 3 & 6 & 0 & 6 & 49 & 1 & 0 & 221 & $0 \%$ \\
\hline Flakes $>10 \mathrm{~cm}$ & 6 & 0 & 0 & 2 & 40 & 125 & 249 & 21 & 301 & 14 & 28 & 11 & 69 & 3 & 54 & 26 & 3 & 13 & 43 & 0 & 0 & 1008 & $1 \%$ \\
\hline Hammerstones & 79 & 0 & 1 & 3 & 129 & 254 & 389 & 32 & 287 & 10 & 34 & 3 & 34 & 0 & 64 & 23 & 19 & 116 & 807 & 20 & 0 & 2304 & $1 \%$ \\
\hline Handaxes & 0 & 0 & 0 & 0 & 4 & 12 & 10 & 1 & 13 & 0 & 0 & 0 & 3 & 0 & 1 & 0 & 0 & 1 & 13 & 0 & 0 & 58 & $0 \%$ \\
\hline Cleavers & 0 & 0 & 0 & 0 & 1 & 3 & 0 & 0 & 0 & 0 & 2 & 0 & 0 & 0 & 0 & 0 & 0 & 0 & 2 & 0 & 0 & 8 & $0 \%$ \\
\hline Total & 4624 & 2 & 8 & 241 & 5269 & 16440 & 20717 & 2053 & 39424 & 3825 & 11623 & 1875 & 12876 & 1763 & 14370 & 3555 & 304 & 9632 & 5224 & 343 & 2 & 154170 & $100 \%$ \\
\hline$\%$ & $0 \%$ & $0 \%$ & $0 \%$ & $0 \%$ & $3 \%$ & $11 \%$ & $13 \%$ & $1 \%$ & $26 \%$ & $2 \%$ & $8 \%$ & $1 \%$ & $8 \%$ & $1 \%$ & $9 \%$ & $2 \%$ & $0 \%$ & $6 \%$ & $3 \%$ & $0 \%$ & $0 \%$ & 10 & \\
\hline
\end{tabular}


Table 2

General features of the core technology at Menez-Dregan I (after Ravon, 2017a). ${ }^{a}$

\begin{tabular}{|c|c|c|c|c|c|c|c|}
\hline SU & $n$ & $\%$ & Sample & $\begin{array}{l}\text { Flaking } \\
\text { surfaces }\end{array}$ & Scars & Percussion & $\begin{array}{c}\text { Main scar } \\
\text { organizations }^{b}\end{array}$ \\
\hline $9 a$ & 371 & $8 \%$ & 76 & $1-4$ & $1-15$ & Hard/On anvil & LU/OR \\
\hline $8 \mathrm{c}$ & 38 & $15.8 \%$ & - & - & - & - & - \\
\hline $8 b$ & 638 & $12.1 \%$ & 35 & $1-3$ & $1-11$ & Hard/Soft/On anvil & TU/OR/CENTR \\
\hline 7 & 1599 & $9.7 \%$ & 37 & $1-3$ & $1-17$ & Hard/Soft/On anvil & TU/CENTR \\
\hline $6^{\prime}$ & 2618 & $12.6 \%$ & 242 & $1-3$ & $1-17$ & $\begin{array}{l}\text { Hard/Soft / On } \\
\text { anvil }\end{array}$ & CENTR/TB/On flake \\
\hline $5 e$ & 349 & $17 \%$ & 36 & $1-3$ & $1-9$ & Hard/On anvil & OR/TU/TB/On flake \\
\hline $5 d^{\prime}$ & 5625 & $14.3 \%$ & 18 & $1-2$ & $1-10$ & Hard/Soft/On anvil & OR/Unip/TB/CENTR \\
\hline $5 d$ & 367 & $9.6 \%$ & 15 & $1-2$ & $1-8$ & Hard/On anvil & TU/CENTR/TB \\
\hline $5 c^{\prime}$ & 1079 & $9.3 \%$ & 9 & $1-2$ & $1-12$ & Hard/On anvil & TU/CENTR \\
\hline $5 c$ & 250 & $13.3 \%$ & 16 & $1-2$ & $1-11$ & Hard & OR/CENTR/TU \\
\hline $5 b^{\prime}$ & 1629 & $12.7 \%$ & 20 & $1-2$ & $2-9$ & Hard/On anvil & OR/LU/CENTR \\
\hline $5 b$ & 194 & $11 \%$ & 7 & $1-2$ & $4-7$ & Hard/On anvil & CENTR \\
\hline $5 a^{\prime}$ & 1164 & $8.1 \%$ & 17 & $1-2$ & $1-8$ & Hard/On anvil & LU/OR/On flake \\
\hline $5 a$ & 403 & $11.3 \%$ & 8 & $1-2$ & $1-6$ & Hard/On anvil & TU/OR/CENTR \\
\hline $4 c$ & 819 & $8.5 \%$ & 424 & $1-3$ & $1-11$ & Hard/On anvil & OR/CENTR/LU \\
\hline $4 a b$ & 445 & $8.5 \%$ & 324 & $1-3$ & $1-13$ & Hard/On anvil & CENTR \\
\hline Total & 17684 & & 1284 & $1-4$ & $1-17$ & & \\
\hline
\end{tabular}

$\mathrm{SU}=$ stratigraphical Unit.

avariable definitions: $n=$ number of cores within each SU \% = percentage of cores out of the assemblage in each SU; Sample = number of cores studied in details in each SU; Flaking surfaces: number of surfaces flaked during the knapping process; Scars: number of removals observed on each core

bPattern of removals on each side of the core according to its longest side: $L U=$ longitudinal unipolar; OR = orthogonal; TU = transversal unipolar; CENTR $=$ centripetal; TB $=$ transversal bipolar; Unip = unipolar. 
Table 3

Technological features used in this study to analyze handaxes following García-Medrano et al. (2020a).

\begin{tabular}{|l|l|l|l|}
\hline \multicolumn{2}{|l|}{ Tool as a single unit } & \multicolumn{2}{c|}{ Tool in three parts ${ }^{\text {a }}$} \\
\hline \multicolumn{1}{|c|}{ Raw Material } & \multicolumn{1}{|c|}{ Type } & \multicolumn{1}{c|}{ Hammer } & \multicolumn{1}{c|}{ Hard, soft } \\
\hline Blank & Slab, flake, unknown & Presence of cortex & $\%$ \\
\hline Number of faces & Bifacial, unifacial & Removal series & $\begin{array}{l}1,2 \text {, (or more), final retouch } \\
\text { or combined }\end{array}$ \\
\hline Cortex localization & Butt, mid-butt, middle, tip & Depth scars on edge & Marginal, deep \\
\hline Edge delineation & Straight, sinuous, incurved & $\begin{array}{l}\text { Invasiveness } \\
\text { (per each removal } \\
\text { series) }\end{array}$ & Invasive, non-invasive \\
\hline Profile symmetry & $\begin{array}{l}\text { Symmetric, non-symmetric, } \\
\text { plano-convex }\end{array}$ & Final retouch & Invasive, non-invasive \\
\cline { 3 - 4 } & & $\begin{array}{l}\text { Specific types (e.g., } \\
\text { tranchet) }\end{array}$ \\
\hline Number of scars & $>10$ mm & Type shaping & General, specific \\
\hline
\end{tabular}

${ }^{a}$ All of these features are recorded for each part of the tool. 
Table 4

Raw material distribution through the entire stratigraphical sequence at Menez-Dregan I.

\begin{tabular}{|c|c|c|c|c|c|c|c|c|c|c|c|c|c|}
\hline \multirow{2}{*}{ Unit } & \multicolumn{2}{|c|}{$\begin{array}{c}\text { Glossy } \\
\text { sandstone }\end{array}$} & \multicolumn{2}{|c|}{ Quartz } & \multicolumn{2}{|c|}{ Quartzite } & \multicolumn{2}{|c|}{ Microgranite } & \multicolumn{2}{|c|}{ Sandstone } & \multicolumn{2}{|c|}{ Flint } & \multirow{2}{*}{$\begin{array}{c}\text { TOTAL } \\
n\end{array}$} \\
\hline & $n$ & $\%$ & $n$ & $\%$ & $n$ & $\%$ & $n$ & $\%$ & $n$ & $\%$ & $n$ & $\%$ & \\
\hline $9 a$ & 6 & 0.1 & 1619 & 35 & 64 & 1.4 & 58 & 1.3 & 195 & 4.2 & 2682 & 58 & 4624 \\
\hline $8 c$ & 0 & 0 & 56 & 23.2 & 5 & 2.1 & 1 & 0.4 & 16 & 6.6 & 163 & 67.6 & 241 \\
\hline $8 b$ & 43 & 0.8 & 848 & 16.1 & 93 & 1.8 & 276 & 5.2 & 600 & 11.4 & 3409 & 64.7 & 5269 \\
\hline 7 & 271 & 1.6 & 2640 & 16.1 & 260 & 1.6 & 1128 & 6.9 & 2039 & 12.4 & 10102 & 61.4 & 16440 \\
\hline $6^{\prime}$ & 337 & 1.6 & 2676 & 12.9 & 113 & 0.5 & 877 & 4.2 & 2282 & 11 & 14432 & 69.7 & 20717 \\
\hline $5 e$ & 17 & 0.8 & 316 & 15.4 & 11 & 0.5 & 67 & 3.3 & 190 & 9.3 & 1452 & 70.7 & 2053 \\
\hline $5 d^{\prime}$ & 332 & 0.8 & 5071 & 12.9 & 123 & 0.3 & 1083 & 2.7 & 2936 & 7.4 & 29879 & 75.8 & 39424 \\
\hline $5 d$ & 31 & 0.8 & 457 & 11.9 & 19 & 0.5 & 92 & 2.4 & 185 & 4.8 & 3041 & 79.5 & 3825 \\
\hline $5 c^{\prime}$ & 106 & 0.9 & 1503 & 12.9 & 44 & 0.4 & 308 & 2.6 & 590 & 5.1 & 9072 & 78.1 & 11623 \\
\hline $5 c$ & 21 & 1.1 & 274 & 14.6 & 8 & 0.4 & 67 & 3.6 & 107 & 5.7 & 1398 & 74.6 & 1875 \\
\hline $5 b^{\prime}$ & 161 & 1.3 & 1862 & 14.5 & 57 & 0.4 & 597 & 4.6 & 946 & 7.3 & 9253 & 72 & 12876 \\
\hline $5 b$ & 16 & 0.9 & 341 & 19.3 & 11 & 0.6 & 64 & 3.6 & 95 & 5.4 & 1236 & 70.1 & 1763 \\
\hline $5 a^{\prime}$ & 159 & 1.1 & 2008 & 14 & 72 & 0.5 & 309 & 2.2 & 774 & 5.4 & 11048 & 76.9 & 14370 \\
\hline $5 a$ & 17 & 0.5 & 571 & 16.1 & 23 & 0.6 & 133 & 3.7 & 239 & 6.7 & 2572 & 72.3 & 3555 \\
\hline $4 c$ & 74 & 0.8 & 1308 & 13.6 & 55 & 0.6 & 368 & 3.8 & 680 & 7.1 & 7147 & 74.2 & 9632 \\
\hline $4 a b$ & 19 & 0.4 & 544 & 10.4 & 62 & 1.2 & 706 & 13.5 & 1603 & 30.7 & 2290 & 43.8 & 5224 \\
\hline TOTAL & 1610 & 1.0 & 22094 & 14.4 & 1020 & 0.7 & 6134 & 4.0 & 13477 & 8.8 & 109176 & 71.1 & 153511 \\
\hline
\end{tabular}




\section{Table 5}

General features form each stratigraphic unit (SU) from Menez-Dregan I. ${ }^{a}$

\begin{tabular}{|c|c|c|c|c|c|c|c|c|c|c|c|c|c|}
\hline Unit & MIS & $n$ & $\%$ & Fire & Charcoal & Fauna & Cores & $\begin{array}{c}\text { Flakes/flake } \\
\text { fragments }\end{array}$ & Percussion & Choppers & Handaxes & $\begin{array}{c}\text { Cleaver } \\
\mathrm{s}\end{array}$ & Small tools \\
\hline SU 9a & 12 & 4624 & $99.9 \%$ & 1 hearth & $\begin{array}{l}\text { Bone } \\
\text { Wood }\end{array}$ & Yes & $8 \%$ & $71.2 \%$ & $\begin{array}{l}\text { Hard } \\
\text { On anvil }\end{array}$ & $0.1 \%$ & No & No & $2.1 \%$ \\
\hline SU 8c & \multirow[t]{2}{*}{11} & 241 & $4.4 \%$ & No hearth & Wood & No & $15.8 \%$ & $73.5 \%$ & $\begin{array}{l}\text { Hard } \\
\text { On anvil }\end{array}$ & $0 \%$ & No & No & $6.2 \%$ \\
\hline SU 8b & & 5269 & $95.6 \%$ & $\begin{array}{l}\text { Small } \\
\text { traces of } \\
\text { hearths }\end{array}$ & $\begin{array}{l}\text { Bone } \\
\text { Wood }\end{array}$ & No & $12.1 \%$ & $73.8 \%$ & $\begin{array}{l}\text { Hard/Soft } \\
\text { On anvil }\end{array}$ & $2.7 \%$ & $0.08 \%$ & $0.02 \%$ & $5.6 \%$ \\
\hline SU 7 & 10 & 16440 & $100 \%$ & $\begin{array}{l}\text { Several } \\
\text { hearths }\end{array}$ & $\begin{array}{l}\text { Bone } \\
\text { Wood }\end{array}$ & Yes & $9.7 \%$ & $79.6 \%$ & $\begin{array}{l}\text { Hard/Soft } \\
\text { On anvil }\end{array}$ & $1.5 \%$ & $0.07 \%$ & $0.02 \%$ & $3.5 \%$ \\
\hline SU 6' & $9 c$ & 20717 & $100 \%$ & 1 Hearth & $\begin{array}{l}\text { Bone } \\
\text { Wood }\end{array}$ & No & $12.6 \%$ & $77.8 \%$ & $\begin{array}{l}\text { Hard/Soft } \\
\text { On anvil }\end{array}$ & $1.5 \%$ & $0.05 \%$ & No & $2.8 \%$ \\
\hline SU $5 e$ & \multirow[t]{8}{*}{$9 a$} & 2053 & $2.25 \%$ & 1 Hearth & $\begin{array}{l}\text { Bone } \\
\text { Wood }\end{array}$ & No & $17 \%$ & $78.3 \%$ & $\begin{array}{l}\text { Hard } \\
\text { On anvil }\end{array}$ & $0.7 \%$ & $0.05 \%$ & No & $0.8 \%$ \\
\hline SU 5d' & & 39424 & $43.16 \%$ & $\begin{array}{l}\text { No hearth } \\
(0.5 \% \\
\text { signs of } \\
\text { heating })\end{array}$ & $\begin{array}{l}\text { Bone } \\
\text { Wood }\end{array}$ & No & $14.3 \%$ & $82.4 \%$ & $\begin{array}{l}\text { Hard/Soft } \\
\text { On anvil }\end{array}$ & $0.5 \%$ & $0.03 \%$ & No & $0.8 \%$ \\
\hline SU $5 d$ & & 3825 & $4.18 \%$ & 1 Hearth & $\begin{array}{l}\text { Bone } \\
\text { Wood }\end{array}$ & No & $9.6 \%$ & $88.4 \%$ & $\begin{array}{l}\text { Hard } \\
\text { On anvil }\end{array}$ & $0.3 \%$ & No & No & $0.8 \%$ \\
\hline SU 5c' & & 11623 & $12.72 \%$ & $\begin{array}{l}\text { No hearth } \\
(0.7 \% \\
\text { signs of } \\
\text { heating })\end{array}$ & $\begin{array}{l}\text { Bone } \\
\text { Wood }\end{array}$ & No & $9.3 \%$ & $88.5 \%$ & $\begin{array}{l}\text { Hard } \\
\text { On anvil }\end{array}$ & $0.2 \%$ & No & $0.02 \%$ & $1.3 \%$ \\
\hline SU 5c & & 1875 & $2.05 \%$ & 1 Hearth & $\begin{array}{l}\text { Bone } \\
\text { Wood }\end{array}$ & Yes $^{b}$ & $13.3 \%$ & $83.3 \%$ & Hard & $0.3 \%$ & No & No & $2 \%$ \\
\hline SU 5b' & & 12855 & $14.07 \%$ & $\begin{array}{l}\text { No hearth } \\
(0.5 \% \\
\text { signs of } \\
\text { heating })\end{array}$ & $\begin{array}{l}\text { Bone } \\
\text { Wood }\end{array}$ & No & $12.7 \%$ & $84.4 \%$ & $\begin{array}{l}\text { Hard } \\
\text { On anvil }\end{array}$ & $0.4 \%$ & $0.02 \%$ & No & $1.4 \%$ \\
\hline SU 5b & & 1763 & $1.93 \%$ & $\begin{array}{l}\text { No hearth } \\
(0.5 \% \\
\text { signs of } \\
\text { heating })\end{array}$ & $\begin{array}{l}\text { Bone } \\
\text { Wood }\end{array}$ & No & $11 \%$ & $87.2 \%$ & $\begin{array}{l}\text { Hard } \\
\text { On anvil }\end{array}$ & $0.1 \%$ & No & No & $1.4 \%$ \\
\hline SU 5a' & & 14370 & $15.73 \%$ & $\begin{array}{l}\text { No hearth } \\
(0.9 \% \\
\text { signs of } \\
\text { heating })\end{array}$ & $\begin{array}{l}\text { Bone } \\
\text { Wood }\end{array}$ & No & $8.1 \%$ & $89.4 \%$ & $\begin{array}{l}\text { Hard } \\
\text { On anvil }\end{array}$ & $0.2 \%$ & $0.01 \%$ & No & $1.2 \%$ \\
\hline
\end{tabular}




\begin{tabular}{|c|c|c|c|c|c|c|c|c|c|c|c|c|c|}
\hline SU $5 a$ & & 3555 & $3.89 \%$ & $\begin{array}{l}\text { No hearth } \\
(12.8 \% \\
\text { signs of } \\
\text { heating) }\end{array}$ & $\begin{array}{l}\text { Bone } \\
\text { Wood }\end{array}$ & No & $11.3 \%$ & $85.7 \%$ & $\begin{array}{l}\text { Hard } \\
\text { On anvil }\end{array}$ & $0.3 \%$ & No & No & $0.8 \%$ \\
\hline SU 4c & $8 e$ & 9632 & $63.04 \%$ & $\begin{array}{l}\text { No hearth } \\
(0.8 \% \\
\text { signs of } \\
\text { heating })\end{array}$ & Wood & No & $8.5 \%$ & $83.4 \%$ & $\begin{array}{l}\text { Hard } \\
\text { On anvil }\end{array}$ & $0.3 \%$ & $0.01 \%$ & No & $2.6 \%$ \\
\hline SU 4ab & & 5224 & $36.95 \%$ & $\begin{array}{l}\text { No hearth } \\
(1.8 \% \\
\text { signs of } \\
\text { heating) }\end{array}$ & Wood & No & $8.5 \%$ & $61 \%$ & $\begin{array}{l}\text { Hard/On } \\
\text { anvil }\end{array}$ & $1.6 \%$ & $0.25 \%$ & $0.03 \%$ & $1.6 \%$ \\
\hline
\end{tabular}

Abbreviations: MIS = MIS attribution for each SU.

avariable definitions: $n=$ number of artifacts within each SU\% = percentage of artifacts out of the total assemblage of the site; fire = presence/absence of hearths; charcoal = presence of bone/wood charcoal; fauna = presence/absence of altered faunal remains; cores = percentage of cores out of the total assemblage for each SU; flakes/flake fragments = percentage of flakes and flake fragments out of the total assemblage for each SU; percussion = type of percussion used for knapping and/or shaping; choppers = percentage of choppers out of the out of the total assemblage for each SU; handaxes = absence or presence and percentage out of the total assemblage for each SU; cleavers = absence or presence and percentage out of the total assemblage for each SU; small tools = percentage of small retouched tools out of the total assemblage for each SU.

${ }^{\mathrm{b}}$ Fragment of molar of Elephas. 
Table 6

Handaxes and cleavers by raw materials and levels.

\begin{tabular}{|c|c|c|c|c|c|c|c|c|c|c|c|}
\hline \multirow{2}{*}{ Layers } & \multicolumn{2}{|c|}{ Flint } & \multicolumn{2}{|c|}{ Quartz } & \multicolumn{2}{c|}{ Quartzite } & \multicolumn{2}{c|}{ Microgranite } & \multicolumn{2}{c|}{ Sandstone } & \multirow{2}{*}{ Total } \\
\cline { 2 - 12 } & $n$ & $\%$ & $n$ & $\%$ & $n$ & $\%$ & $n$ & $\%$ & $n$ & $\%$ & \\
\hline Layer 4 & - & - & 1 & 6.25 & - & - & 2 & 12.50 & 13 & 81.25 & 16 \\
\hline Layer 5 & 1 & 5.00 & - & - & 1 & 5.00 & 9 & 45.00 & 9 & 45.00 & 20 \\
\hline Layer 6 & - & - & - & - & 1 & 10.00 & 4 & 40.00 & 5 & 50.00 & 10 \\
\hline Layer 7 & - & - & 1 & 6.67 & 4 & 26.67 & 5 & 33.33 & 5 & 33.33 & 15 \\
\hline Layer 8 & - & - & 1 & 20.00 & - & - & 1 & 20.00 & 3 & 60.00 & 5 \\
\hline TOTAL & 1 & 1.52 & 3 & 4.55 & 6 & 9.09 & 21 & 31.82 & 35 & 53.03 & 66 \\
\hline
\end{tabular}


Table 7

Euclidean distances of handaxes and cleavers by layers and types of blanks (cobble, flakes and unknown blanks). Data extracted from Figure 4.

\begin{tabular}{|c|c|c|c|c|c|c|c|c|c|c|c|c|}
\hline \multicolumn{2}{|c|}{ Euclidean distance } & \multicolumn{2}{|c|}{ Layer 4} & \multicolumn{2}{|c|}{ Layer 5} & \multicolumn{2}{|c|}{ Layer 6} & \multicolumn{3}{|c|}{ Layer 7} & \multicolumn{2}{|c|}{ Layer 8} \\
\hline Layers & Blanks & Cobble & Flake & Cobble & Flake & Cobble & Flake & Cobble & Flake & Unknown & Flake & Unknown \\
\hline \multirow[t]{2}{*}{ Layer 4} & Cobble & 0 & 170.01 & 240.38 & 227.10 & 290.60 & 194.69 & 352.77 & 245.24 & 317.98 & 268.74 & 255.49 \\
\hline & Flake & 170.01 & 0 & 222.68 & 156.58 & 314.35 & 158.05 & 362.11 & 222.70 & 316.79 & 232.63 & 245.28 \\
\hline \multirow[t]{2}{*}{ Layer 5} & Cobble & 240.38 & 222.68 & 0 & 186.33 & 331.66 & 230.40 & 374.17 & 253.59 & 393.70 & 309.12 & 350.00 \\
\hline & Flake & 227.10 & 156.58 & 186.33 & 0 & 386.93 & 159.37 & 331.24 & 159.71 & 367.04 & 231.94 & 309.11 \\
\hline \multirow[t]{2}{*}{ Layer 6} & Cobble & 290.60 & 314.35 & 331.66 & 386.93 & 0 & 334.63 & 447.21 & 387.48 & 412.31 & 381.52 & 409.27 \\
\hline & Flake & 194.69 & 158.05 & 230.40 & 159.37 & 334.63 & 0 & 334.63 & 220.45 & 315.84 & 236.75 & 265.69 \\
\hline \multirow[t]{3}{*}{ Layer 7} & Cobble & 352.77 & 362.11 & 374.17 & 331.24 & 447.21 & 334.63 & 0 & 356.10 & 447.21 & 372.68 & 444.41 \\
\hline & Flake & 245.24 & 222.70 & 253.59 & 159.71 & 387.48 & 220.45 & 356.10 & 0 & 369.88 & 222.68 & 320.38 \\
\hline & Unknown & 317.98 & 316.79 & 393.70 & 367.04 & 412.31 & 315.84 & 447.21 & 369.88 & 0 & 381.52 & 259.81 \\
\hline \multirow[t]{2}{*}{ Layer 8} & Flake & 268.74 & 232.63 & 309.12 & 231.94 & 381.52 & 236.75 & 372.68 & 222.68 & 381.52 & 0 & 264.05 \\
\hline & Unknown & 255.49 & 245.28 & 350.00 & 309.11 & 409.27 & 265.69 & 444.41 & 320.38 & 259.81 & 264.05 & 0 \\
\hline
\end{tabular}


Table 8

Intra-assemblage shape variability and their distribution of relative shape variability across dimensions. ${ }^{\mathrm{a}}$

\begin{tabular}{|c|c|c|c|c|c|c|}
\hline \multirow{2}{*}{\multicolumn{2}{|c|}{ Variable }} & \multirow{3}{*}{$\begin{array}{l}n \\
7\end{array}$} & \multirow{3}{*}{$\begin{array}{c}\begin{array}{c}\text { Shape } \\
\text { variability }\end{array} \\
7.42\end{array}$} & \multicolumn{3}{|c|}{$\%$ of variability accounted for by: } \\
\hline & & & & \multirow{2}{*}{$\begin{array}{c}\mathrm{x} \text { (width) } \\
44.98\end{array}$} & \multirow{2}{*}{$\begin{array}{c}\mathrm{y} \text { (length) } \\
2.74\end{array}$} & \multirow{2}{*}{$\begin{array}{c}z \text { (thickness) } \\
52.28\end{array}$} \\
\hline \multirow{3}{*}{ Blank } & Cobble & & & & & \\
\hline & Flake & 55 & 8.97 & 47.04 & 3.69 & 49.26 \\
\hline & Unknown & 4 & 7.59 & 26.49 & 1.19 & 72.32 \\
\hline \multirow{4}{*}{$\begin{array}{c}\text { Raw } \\
\text { material }\end{array}$} & Quartz & 3 & 7.31 & 31.77 & 6.07 & 62.16 \\
\hline & Quartzite & 6 & 8.38 & 42.87 & 3.37 & 53.76 \\
\hline & Sandstone & 36 & 8.43 & 48.42 & 3.46 & 48.12 \\
\hline & Microgranite & 20 & 9.34 & 45.89 & 3.86 & 50.24 \\
\hline \multirow{5}{*}{ Layers } & Layer 4 & 16 & 8.96 & 45.98 & 5.27 & 48.74 \\
\hline & Layer 5 & 20 & 8.42 & 47.57 & 3.97 & 48.46 \\
\hline & Layer 6 & 16 & 8.31 & 40.5 & 1.91 & 57.58 \\
\hline & Layer 7 & 14 & 9.11 & 44.5 & 2.46 & 53.04 \\
\hline & Layer 8 & 6 & 7.93 & 42.06 & 3.39 & 54.56 \\
\hline
\end{tabular}

ashape variability is measured as the mean multidimensional Euclidean distance of all artifacts from its centroid). The distribution of relative shape variability across dimensions is calculated as the proportion of variability in each homologous semi-landmark coordinate for each specific dimension. 
Table 9

Summary statistics for deviation from perfect bilateral and bifacial symmetry and edge irregularity.

\begin{tabular}{|c|c|c|c|c|c|}
\hline Blank & Deviation & $\begin{array}{l}\text { Deviation from } \\
\text { bilateral symmetry }\end{array}$ & $\begin{array}{l}\text { Deviation from } \\
\text { bifacial symmetry }\end{array}$ & $\begin{array}{l}\text { Left edge } \\
\text { irregularity }\end{array}$ & $\begin{array}{l}\text { Right edge } \\
\text { irregularity }\end{array}$ \\
\hline \multirow{3}{*}{ Cobbles } & Mean & 9.95 & 5.63 & 126.24 & 97.25 \\
\hline & SD & 2.76 & 2.89 & 46.50 & 41.93 \\
\hline & $\mathrm{CV}$ & 0.28 & 0.51 & 0.37 & 0.43 \\
\hline \multirow{3}{*}{ Flakes } & Mean & 7.39 & 6.23 & 108.58 & 101.24 \\
\hline & SD & 2.60 & 2.60 & 48.84 & 38.84 \\
\hline & $\mathrm{CV}$ & 0.35 & 0.42 & 0.45 & 0.38 \\
\hline \multirow{3}{*}{ Unknown } & Mean & 6.18 & 6.91 & 113.55 & 104.89 \\
\hline & SD & 1.77 & 1.67 & 57.04 & 34.46 \\
\hline & $\mathrm{CV}$ & 0.29 & 0.24 & 0.50 & 0.33 \\
\hline
\end{tabular}

Abbreviations: SD = standard deviation; $\mathrm{CV}=$ coefficient of variation. 


\section{Table 10}

Main characteristics and interpretation of the human occupation levels at Menez-Dregan I. Tool production is the dominant feature of all levels and there is evidence of burnt materials (but not necessarily hearths) throughout. The interpretations of the environment and coastline are mainly based on the suggested correlation with the MIS record. ${ }^{a}$

\begin{tabular}{|c|c|c|c|c|c|c|c|c|c|}
\hline Unit & MIS & $\begin{array}{l}\text { Cores/ } \\
\text { flakes }\end{array}$ & Choppers & Handaxes/cleavers & Small tools & $\begin{array}{l}\text { Glossy } \\
\text { sandstone }\end{array}$ & Environment & Coast & Interpretation and main characteristics \\
\hline SU 9a & 12 & Low & Low & - & Med & No & Cold, tundra & $\begin{array}{c}5- \\
10 \mathrm{~km}\end{array}$ & $\begin{array}{l}\text { Long occupation with hearth. Choppers made and used or taken } \\
\text { offsite. }\end{array}$ \\
\hline SU 8c & & Medium & - & - & High & No & Temperate & $0-1 \mathrm{~km}$ & Brief occupation. Possibly reworked from layer 9. \\
\hline SU $8 b$ & 11 & Medium & High & High & High & Yes & Temperate & $0-1 \mathrm{~km}$ & $\begin{array}{l}\text { Long occupation, traces of hearths. Choppers, handaxes made } \\
\text { and used on site. Handaxes in flint and glossy sandstone made } \\
\text { on site, but used offsite. Numerous scrapers. }\end{array}$ \\
\hline SU 7 & 10 & Medium & Medium & Medium & Med & Yes & Cold, tundra & $\begin{array}{c}5- \\
10 \mathrm{~km}\end{array}$ & $\begin{array}{l}\text { Several short occupations with hearths. Choppers, handaxes } \\
\text { made and used on site. Flint handaxes made on site, but used } \\
\text { offsite. Numerous scrapers. }\end{array}$ \\
\hline SU 6 & $9 c$ & High & Medium & Medium & Med & Yes & Temperate & $0-1 \mathrm{~km}$ & $\begin{array}{l}\text { Long occupation, dwelling place with hearth on raised beach. } \\
\text { Choppers, handaxes made and used on site. Flint handaxes } \\
\text { made on site, but used offsite. Moderate numbers retouched } \\
\text { tools. }\end{array}$ \\
\hline SU $5 e$ & \multirow{7}{*}{$9 a$} & High & Low & Medium & Low & Yes & $\begin{array}{c}\text { Cool- } \\
\text { temperate }\end{array}$ & $1-5 \mathrm{~km}$ & $\begin{array}{l}\text { Short occupation with hearth. Quartzite cores used, but taken } \\
\text { offsite. Choppers, handaxes made and used on site. }\end{array}$ \\
\hline SU 5d' & & High & Low & Low & Low & Yes & $\begin{array}{c}\text { Cool- } \\
\text { temperate }\end{array}$ & $1-5 \mathrm{~km}$ & $\begin{array}{l}\text { Long occupation. Rare macro tools made and used on site. } \\
\text { Intensive production, most tools used offsite. }\end{array}$ \\
\hline SU $5 d$ & & High & Low & - & Low & Yes & $\begin{array}{l}\text { Cool- } \\
\text { temperate }\end{array}$ & $1-5 \mathrm{~km}$ & $\begin{array}{l}\text { Short occupation, dwelling place with hearth. Rare choppers, } \\
\text { retouched tools made and used on site. No handaxes used or } \\
\text { made onsite. }\end{array}$ \\
\hline SU 5c' & & High & Low & Low & Low & Yes & $\begin{array}{c}\text { Cool- } \\
\text { temperate }\end{array}$ & $1-5 \mathrm{~km}$ & $\begin{array}{l}\text { Long occupation. Rare macro tools, retouched tools made and } \\
\text { used onsite. Other activities offsite. }\end{array}$ \\
\hline SU $5 c$ & & High & Low & - & Medium & Yes & $\begin{array}{c}\text { Cool- } \\
\text { temperate }\end{array}$ & $1-5 \mathrm{~km}$ & $\begin{array}{l}\text { Short occupation with hearth. Abundant scrapers, Choppers } \\
\text { made onsite, some removed. }\end{array}$ \\
\hline SU 5b' & & High & Low & Low & Low & Yes & $\begin{array}{l}\text { Cool- } \\
\text { temperate }\end{array}$ & $1-5 \mathrm{~km}$ & $\begin{array}{l}\text { Long occupation. Choppers, handaxes made and used onsite. } \\
\text { Handaxes in flint and quartzite made, but used offsite. Few } \\
\text { retouched tools. }\end{array}$ \\
\hline SU 5b & & High & Low & - & Low & Yes & $\begin{array}{c}\text { Cool- } \\
\text { temperate }\end{array}$ & $1-5 \mathrm{~km}$ & $\begin{array}{l}\text { Short occupation. Choppers made onsite, taken offsite. Few } \\
\text { retouched tools. }\end{array}$ \\
\hline
\end{tabular}




\begin{tabular}{|c|c|c|c|c|c|c|c|c|c|}
\hline SU 5a' & & High & Low & Low & Low & Yes & $\begin{array}{l}\text { Cool- } \\
\text { temperate }\end{array}$ & $1-5 \mathrm{~km}$ & $\begin{array}{l}\text { Long occupation, no hearth. Choppers, handaxes made on site, } \\
\text { used offsite. Few retouched tools. Flint handaxe brought into } \\
\text { site. }\end{array}$ \\
\hline SU 5a & & High & Low & - & Low & Yes & $\begin{array}{l}\text { Cool- } \\
\text { temperate }\end{array}$ & $1-5 \mathrm{~km}$ & $\begin{array}{l}\text { Short occupation with intense production. Macro tools made, } \\
\text { taken offsite. Few retouched tools. No hearth, but abundant } \\
\text { burnt flint. }\end{array}$ \\
\hline SU 4c & & High & Low & Low & Medium & Yes & Cold, tundra & $\begin{array}{c}5- \\
10 \mathrm{~km}\end{array}$ & $\begin{array}{l}\text { Long occupation. Rare choppers, handaxes shaped offsite, } \\
\text { finished onsite and used. Frequent small tools. }\end{array}$ \\
\hline SU 4ab & $8 e$ & Low & Medium & High & Low & Yes & Cold, tundra & $\begin{array}{c}5- \\
10 \mathrm{~km}\end{array}$ & $\begin{array}{l}\text { Short occupation, dwelling place on pavement. Production and } \\
\text { use onsite. Abundant Choppers, handaxes. Few small tools. } \\
\text { Centripetal cores and first discoid cores. Transition to Middle } \\
\text { Palaeolithic. }\end{array}$ \\
\hline
\end{tabular}

aCores/flakes: $>90 \%=$ High; $80-90 \%$ = medium; $<80 \%=$ low; Choppers: $>2 \%$ = high; $1-2 \%=$ medium; $<1 \%=$ low; Handaxes/cleavers: $>0.1 \%$ $=$ high; $0.05-0.1 \%=$ medium; $<0.05 \%=$ low; Small tools: $>4 \%=$ high; $2-4 \%=$ medium; $<2 \%=$ low. See text and General technological composition of each level in Supplementary Online Material SOM S1 for more detailed description and interpretation. 


\section{Supplementary Online Material (SOM):}

Acheulean variability in Western Europe: The case of Menez-Dregan I (Plouhinec, Finistère, France)

Anne-Lyse Ravona, ${ }^{a}$, Paula García-Medrano ${ }^{\mathrm{b}, \mathrm{c}, \mathrm{d}, \mathrm{e}}$, Marie-Hélène Moncel ${ }^{\mathrm{b}}$, Nick Ashton $^{\mathrm{C}}$

a Université de Rennes, CNRS, Ministère de la Culture et de la Communication, CReAAH-UMR 6566, 35042 Rennes cedex, France

b Department of Prehistory, CNRS-UMR 7194, National Museum of Natural History, Institut de Paléontologie Humaine, 1 rue René Panhard, 75013 Paris, France

${ }^{c}$ Department Britain, Europe and Prehistory, British Museum, Frank House, 56 Orsman Road N1 5QJ, London, UK

d Institut Català de Paleoecologia Humana i Evolució Social (IPHES-CERCA), Zona Educacional 4, Campus Sescelades URV (Edifici W3), 43007 Tarragona, Spain

e Universitat Rovira i Virgili, Departament d'Història i Història de l'Art, Avinguda de Catalunya 35, 43002 Tarragona, Spain

*Corresponding author:

Email address: al.ravon@hotmail.fr (A-L Ravon) 


\section{SOM S1}

\section{General technological composition of each level}

Layer 9 (MIS 12), composed of the three stratigraphic units (SU) 9a, 9b and 9c, includes 4,624 artifacts, almost all in SU 9a. For this occupation attributed to the end of MIS 12 , a domestic use of the cave seems to emerge, with a hearth in SU 9a. Macro-tools are very scarce (only five choppers and no chopping tools), but were probably used offsite after being manufactured in situ (or taken offsite after in situ manufacture and use), as suggested by the quantity of sandstone and microgranite flakes and flake fragments and lack of cores in these raw materials. Small tools are not very common in SU 9 a $(2.1 \%)$, while cores $(8 \%)$, flakes $(34 \%)$ and flake fragments $(37,2 \%)$ are abundant. Handaxes and cleavers are totally absent from both levels. It is very likely that SU $9 a$ attests to a relatively continuous occupation of the cave.

Layer 8 (MIS 11) includes 5,510 artifacts and is composed of SU $8 \mathrm{c}(n=241)$ and of SU $8 b(n=5,269)$. SU $8 c$ shows strong similarities with layer 9 , both in terms of lithological and typological composition of the assemblage. Nevertheless, it was discovered recently in 2017 , therefore geoarchaeological analyses are still in progress in order to clarify the conditions of deposition of this level; the material coming from SU 8c could also just be reworked from the underlying SU $9 a$. SU 8b, the main human occupation of layer 8 , is characterized by a fairly high débitage of all materials (12.1\% of cores) except sandstone and microgranite, and primarily flint. It shows a strong production of flakes (44.7\%) detached by hard percussion, and sometimes by soft hammerstones, attested by the use of sandstone for percussive activities. The knapping methods mainly follow a transversal unipolar, orthogonal or centripetal organization (Table 4$)$. The macro-tools (5.1\% of this assemblage) were probably shaped and used on the site; four handaxes and one cleaver are present $(1.9 \%$ of the heavy-duty tools in this SU) and represent the first occurrence of the Acheulean within the region (Ravon, 2017a, b). The presence of a few biface thinning flakes in flint and glossy sandstone suggests that handaxes in these raw materials were manufactured at MDI, and likely removed from the deposit after their shaping and/or use onsite, attesting to a probable higher percentage of handaxes and/or cleavers originally in this SU. Scrapers are numerous in SU $8 b(n=100)$, and together with SU 7 and 5c, show the highest use of these tools on site (SOM Fig. S4). $0.7 \%$ of the artifacts show signs of heating and the presence of several small traces of hearths shows to a high activity on the site, if not several occupations of rather short duration.

SU 7 (MIS 10) is composed of 16,440 pieces, and is characterized by a flake production slightly more frequent than in SU $8 \mathrm{~b}(48.6 \%)$, sometimes detached by a soft hammerstone, with frequent transversal unipolar and centripetal systems (Table 4; SOM Fig. S5). Macro-tools (4.3\%) were produced and used on the site, Acheulean tools (12 handaxes and three cleavers) are also part of the assemblage and represent $2.2 \%$ of the heavy-duty tools of this level. As for SU 8b, the flint handaxes were likely removed from the deposit after being manufactured on site, as suggested by the presence of only a few flint biface thinning flakes and the lack of flint handaxes in the lithic series. Scrapers are twice as numerous in SU 7 than in SU 8b $(n=201)$. Therefore, SU 7 shows strong similarities with SU 8b, especially in the composition of its lithic assemblage (SOM Figs. S1, S2 and S4; SOM Table S1), presenting a division of activities between the deposit itself and the exterior, although this appears less marked than in SU 8b. The flake and tool production and use likely took place onsite, according to the composition of the assemblage (SOM Table S1). SU 7 appears to consist of several small occupation levels of rather short duration that could not be distinguished during the excavation, as they were interbedded into colluvial deposits, frequently discontinuous, and whose surface was eroded by the deposition of layer 6 raised beach. Seven hearths are recorded in this level (Gaillard et al., 2017), additionally micromorphology analyses attest to the presence of abundant bone charcoal in the sediments (Monnier et al., 1996). It seems that human groups repeatedly came to settle on the site and left again (Ravon et al., 2016b; Ravon, 2017a; Ravon and Laforge, 2019). 
SU 6' (MIS 9c) corresponds to a human occupation with a hearth on top of a raised beach, in a rather temperate phase, and probably of a significantly long duration, as suggested by the high number of lithic artifacts in this level, and by the thickness of this deposit (Ravon, 2017a; Ravon and Laforge, 2019). This is the second richest archaeological level of the site, after layer 5, with 20,717 artifacts (SOM Tables S1 and S2). SU 6' is characterized primarily by débitage with $12.6 \%$ cores made from all the raw materials, but mainly flint $(85.5 \%)$, with a strong implementation of bipolar flaking on an anvil. Centripetal and transversal bipolar methods are frequent, and cores on flakes are numerous (Table 4). Soft stone percussion is present again, but less used than in the underlying levels (SU 8b and 7 ). Like the previous layers, the macro-tools have been shaped and used on site (3.8\%). Ten handaxes made from sandstone, microgranite and quartzite cobbles are present within the lithic assemblage, and represent $1.3 \%$ of the macro-tools in this level. Several flint biface thinning flakes were found, but the flint handaxes themselves are absent again, which shows the mobility of the groups that frequented this level, and the organization of the different areas of activity on and around the site. SU 6' also presents all the criteria for a real dwelling place, with a high number of artifacts, relatively frequent retouched and shaped tools, (respectively, $2.8 \%$ and $3.8 \%$ of this series) and the presence of a hearth (Ravon, 2017a).

Layer 5 (MIS 9a) and its many sub-levels alone make up for more than $60 \%$ of the lithic collection from the site, with 91,668 artifacts. Levels $5 d^{\prime}(n=39,424), 5 a '(n=14,370)$, $5 b^{\prime}(n=12,876)$ and $5 c^{\prime}(n=11,623)$ contained most of the artifacts (SOM Table S1).

SU 5 e (2,053 artifacts) corresponds to a human occupation of rather short duration on a dune level (SU 5e-d; Laforge and Monnier, 2011; Laforge, 2012; Ravon and Laforge, 2019), with a fireplace. SU $5 e$ is characterized by very high débitage activity (17\% cores), selectively on flint $(76.5 \%)$, quartz (22\%) and glossy sandstone (1.5\%). Pebbles are flaked with orthogonal, transversal unipolar or bipolar and centripetal systems of exploitation, and flakes are often flaked as well (Table 4). Moreover, quartzite cores were likely removed from the site after knapping, since they are entirely lacking in the assemblage, and because four flakes, six flake fragments and one large flake $(>10 \mathrm{~cm}$ in length) are present in this assemblage (Ravon et al., 2020). Small tools (0.8\%) and to a lesser extent, macro-tools $(2.3 \%)$ are present but infrequent and were likely shaped and used directly onsite, as suggested by the presence of choppers, chopping tools and several flakes and flake fragments in microgranite and sandstone and the lack of cores in these materials. A single handaxe is present in SU $5 \mathrm{e}$, which represents less than $0.1 \%$ of the assemblage. Despite the presence of a hearth, the occupation of this level reflects a picture of rather short-term use of the site, with activities mainly dedicated to flint and quartz knapping.

SU $5 d$ ' is the most important human occupation of the site $(39,424$ artifacts), which was of a fairly long and continuous duration and without any identified hearths, although $0.5 \%$ of the assemblage shows signs of heating. It comprises a large number of cores (14.3\%), with a débitage of all materials, but preferentially flint (80.8\%), using hard hammer and bipolar flaking on an anvil. Cores are mainly orthogonal, unipolar, transversal bipolar, or centripetal (Table 4). Macro-tools are infrequent (1.7\% of this assemblage) and were probably shaped and used onsite, including Acheulean tools (1.9\% of the heavy-duty tools). Small retouched tools are less frequent than macro-tools and constitute only $0.8 \%$ of the artifacts for this level, one of the lowest percentages of the site (SOM Fig. S1; SOM Table S1). SU 5d' presents the characteristics of a rather intensive production site: the main activity seems to be the production and use of unretouched flakes, but it is likely that the location of use of the tools was offsite, hence their low representation within the assemblage, and the absence of a hearth despite the presence of burnt flint, in addition with wood and bone charcoal.

SU $5 d$ (3,825 artifacts) corresponds to a human occupation with a hearth and is characterized by a débitage solely consisting of flint and quartz, with a single quartzite core, and the occasional implementation of bipolar flaking on an anvil. Cores are mainly exploited with a transversal unipolar, centripetal or transversal bipolar organization (Table 4). If the 
macro-tools were also manufactured and used onsite, they are as rare as the small retouched tools ( $0.8 \%$ of the assemblage each). Handaxes and cleavers are completely absent from this level, including their thinning flakes, which could indicate the presence of a group with skills or technical traditions different from the previous ones (Ravon, 2017a, 2019). The deposit was likely used as a production site, with a fairly short-term occupation. However, a hearth was found in SU 5d during the 2005 excavation, which suggests that despite the very small quantity of specialized tools, the dwelling place was onsite. Alternatively, it reflects an area of specialized activities related to the presence of the fireplace, which makes the occupation of SU $5 \mathrm{~d}$ similar to that of SU $5 \mathrm{e}$. The main difference between these two occupations seems to be the Acheulean element present in $5 \mathrm{e}(\mathrm{a}$ sandstone handaxe) and not in $5 \mathrm{~d}$.

SU $5 c^{\prime}$ has no hearth, although $0.7 \%$ of lithic pieces are burnt, and seems to reflect a rather long-term occupation $(11,623$ artifacts, thick sedimentary deposit). The main activity on the site is the production of flakes $(57.3 \%)$ on all raw materials. Cores are mainly on flint $(84.2 \%)$, quartz (14.6\%) and glossy sandstone (0.9\%), plus two on microgranite and one in quartzite. Sandstone pebbles do not seem to have been selected for knapping, but likely shaping activities, as is typical at MDI. Transversal unipolar and centripetal systems of flaking are the most applied in SU 5c' (Table 4). Macro-tools (0.5\%) and small retouched tools $(1.3 \%)$ are almost absent, but seem to have been produced and used onsite, as for the previous layers. Twenty-two choppers are included in the assemblage and were shaped and discarded onsite after use. This level seems to attest to a production site; it is possible that most of the activities took place offsite (relative absence of retouched or shaped tools), where the hearth was likely to be, just as SU $5 d$ '.

SU $5 c(1,875$ artifacts) provided the most structured hearth, at the center of which a fragment of molar of an elephantid had been found (Monnier et al., 2016a, b). The occupation of level $5 \mathrm{c}$ seems to have been of rather short duration, with a very high production of flakes (54.6\%), detached only with hard percussion. Core technology does not show a particular preferred system of exploitation, but orthogonal, centripetal and transversal unipolar methods were applied more often (Table 4). Small retouched tools are more frequent $(2 \%)$ and mostly composed of flint scrapers (SOM Fig. S4). The macro-tools are few $(1.2 \%)$, but were likely shaped onsite, only on sandstone and microgranite, and then probably taken offsite (only five choppers and one chopping-tool shaped from microgranite and sandstone cobbles, but 54 flakes and flake fragments in microgranite, and 95 in sandstone). Handaxes and cleavers are completely lacking. The structured hearth suggests that activities related to its presence occurred on the site, while the activities related to the retouched tools, such as butchery, may have taken place outside. Once again, some distribution of the areas of activity seems to be emerging.

SU $5 b^{\prime}$ displays $0.5 \%$ of artifacts with traces of heating, but no hearth was noticed during the excavation. This level of occupation seems to have been of rather long duration $(12,876$ artifacts) and is characterized by a high production of flakes $(56.4 \%)$, with recurrent use of bipolar flaking on an anvil and soft hammerstones. Orthogonal, longitudinal unipolar and centripetal exploitation systems were preferred for cores (Table 4). Macro-tools (1.2\%) have likely been shaped and/or used on site and taken away afterwards (relatively low numbers, while shaping flakes are very frequent), and small retouched tools are scarce (1.4\%; SOM Fig. S3). Flint and quartzite handaxes were apparently shaped in situ and then taken outside (presence of biface thinning flakes in these materials but absence of handaxes), while those made from different raw materials were probably used and then discarded on site (SOM Table S1). SU 5b' presents the characteristics of a site of production (abundant cores, flakes and flake fragments), more than consumption, according to the very small amount of retouched or shaped tools, and by the absence of a hearth (despite the attested presence of wood and bone charcoal shown by micromorphology analyses). The main place of use of the retouched and manufactured tools must certainly have been outside 
the site, whereas the unretouched flakes seem to have been used and discarded onsite (Ravon, 2017a).

SU $5 b(1,763$ artifacts) has no hearths, but $0.5 \%$ of the lithic artifacts were burnt. It is characterized by an important production of flakes (57.4\%), preferentially on flint (155/194), and a fairly marked implementation of bipolar flaking on anvil. Centripetal cores are more frequent in SU 5b (Table 4). The macro-tools ( $0.5 \%$ of the assemblage) seem to have been manufactured in situ and then used and/or removed (two choppers and one chopping tool in sandstone, but 90 flakes and flake fragments in this material; 62 flakes/flake fragments and two flakes whose dimensions exceed $10 \mathrm{~cm}$ in microgranite, but absence of macro-tools in microgranite). Handaxes and cleavers are absent. Small retouched tools are infrequent $(1.4 \%)$ and made only of flint (SOM Fig. S6). The occupation of this level reflects the use of the cave as a site of production, of rather short duration. The place of use of the tools was likely outside the site, which allows us to compare this occupation to those of SU $5 \mathrm{~d}$ and $5 \mathrm{c}$, which present the same overall organization of space as well as the same overall management of materials.

SU $5 a^{\prime}$ has no hearth, although $0.8 \%$ of the assemblage consists of burnt elements. It seems to indicate an occupation that was of rather long duration (14,370 artifacts). Once again, there is a preponderance of unretouched flakes (62.4\%), and the bipolar flaking on an anvil is well marked. Longitudinal unipolar and orthogonal flaking were preferentially applied to cores in this level, and cores on flakes are frequent (Table 4). The macro-tools seem to have been manufactured on the site and then discarded and/or used somewhere else (shaping flakes on sandstone and microgranite are abundant, whereas only 26 choppers and three chopping tools in these materials are present), and the small retouched tools are scarce (1.2\%; SOM Fig. S6). A single flint handaxe is included in the assemblage, the only one in the entire collection of MDI, and was likely introduced from another location by the hominins occupying this layer (based on the absence of biface thinning flakes in flint). SU 5a' shows similarities to SU 5d', 5c' and 5b', in terms of duration of occupation, intensity of production, composition of the series, and/or of management of raw materials (SOM Fig. S1, S2 and S4; SOM Table S1).

SU 5 a (3,555 artifacts) is characterized by a high production of flakes $(52.3 \%)$ and by a sporadic implementation of bipolar flaking on an anvil. Transversal unipolar, orthogonal and centripetal methods are frequent on cores, mainly on flint $(77.7 \%)$ and quartz $(21.3 \%)$ pebbles. No hearth was found in SU $5 a$, but $1.1 \%$ of the artifacts show traces of heating and wood and bone charcoal are once more evidenced by micromorphology. Here again, small retouched tools are scarce $(0.8 \%)$ and the macro-tools have been shaped and probably used onsite and/or discarded offsite. Handaxes and cleavers are absent, just like in SU 5b, 5c and $5 d$ (shorter-term occupations).

Layer 4 (MIS 8e) corresponds to the last human occupation of the site. According to the current state of research, layer 4 could be placed in MIS 8e, so in a slightly colder phase (Ravon and Laforge, 2019). Layer 4 consists of two very distinct human occupations: one for 4c (9,632 artifacts) and one for 4ab (which includes level 4a and 4b material; 5,224 artifacts in total).

SU $4 \mathrm{c}$ is characterized by débitage that uses all the raw materials of the site, but preferentially flint (no cores in sandstone or microgranite again), with orthogonal, centripetal and longitudinal unipolar cores preferentially (Table 4). Flake production remains predominant (45\%), although less important than in previous levels (SOM Fig. S1; SOM Table S1). The few macro-tools (1.5\%) seem to have been initially shaped offsite, and then finalized on the site, where the tools were also probably used. A single handaxe is present, and small retouched tools are more frequent than before (2.6\%). SU 4c reflects a site of production and activities of fairly long duration, again with a split of activities between the area itself and outside. 
SU $4 a b$ is the last human occupation of the site and marks the transition between the Lower and the Middle Paleolithic (Ravon and Monnier, 2013, Ravon et al., 2016a). It is characterized by a rather lower débitage of all the raw materials than the underlying levels ( $8.5 \%$ cores), but preferentially of flint $(80 \%)$, and by a recurrent implementation of bipolar flaking on an anvil. This level shows the first appearance of discoid cores for the region ( $n$ $=2$ ), as well as the highest frequency of macro-tools of the site (8.8\%; SOM Fig. S7), with a lower proportion of small retouched tools than in SU 4c (1.6\%). Thirteen handaxes and two cleavers are also present (3.2\% of the macro-tools). Centripetal cores are the most frequent in SU 4ab (Table 4), and hammerstones are very abundant (15.4\%). SU 4ab likely attests to a production and activity site, with fewer flakes (31\%) and likely of shorter duration than SU 4c. The pavement structure identified in SU 4b (Ravon and Monnier, 2013; Ravon et al., $2016 \mathrm{a}$ ) is an additional indication of the site being a real dwelling place, where most activities occurred. 


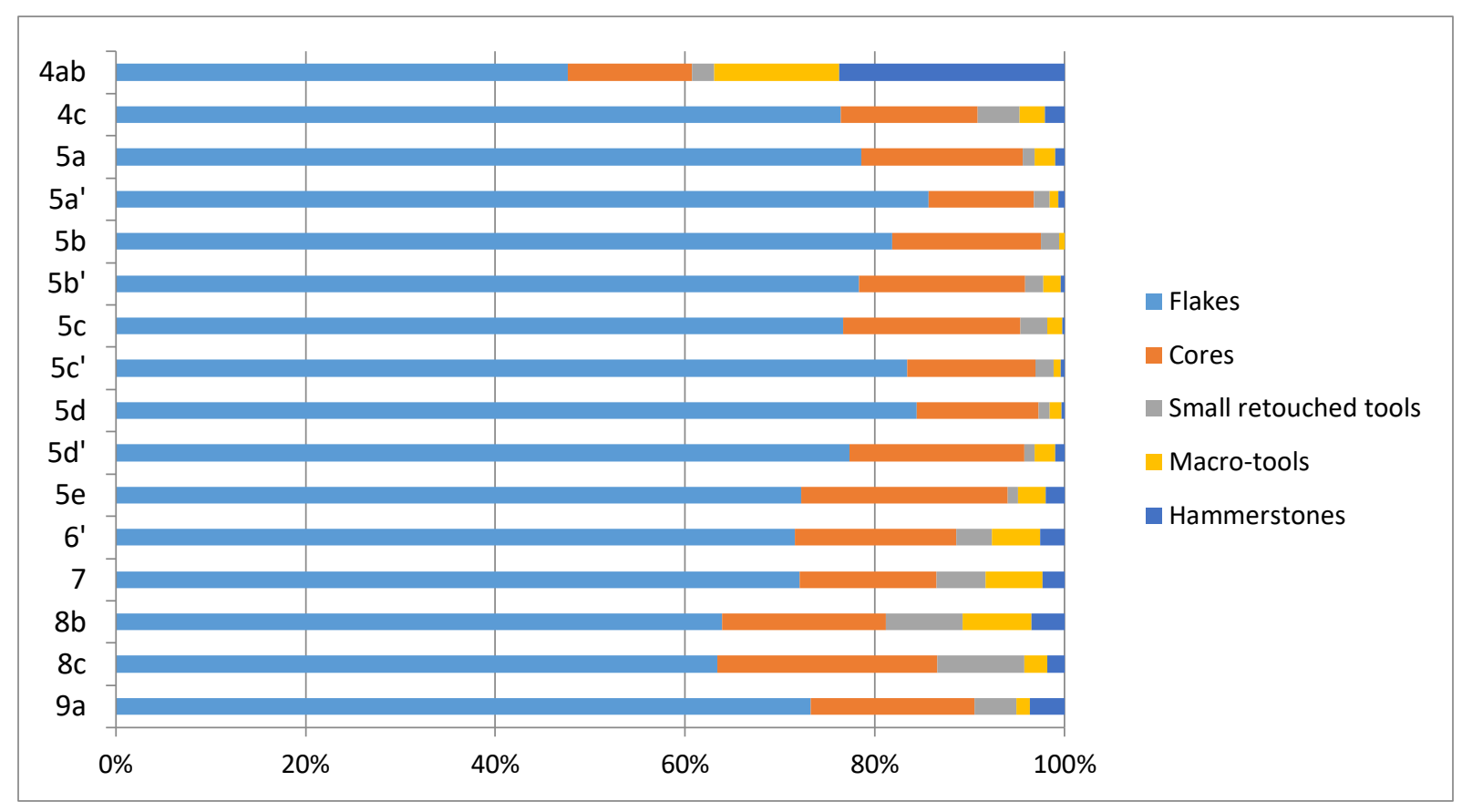

SOM Figure S1. Distribution of the different artifact types according to the 17 archaeological layers.

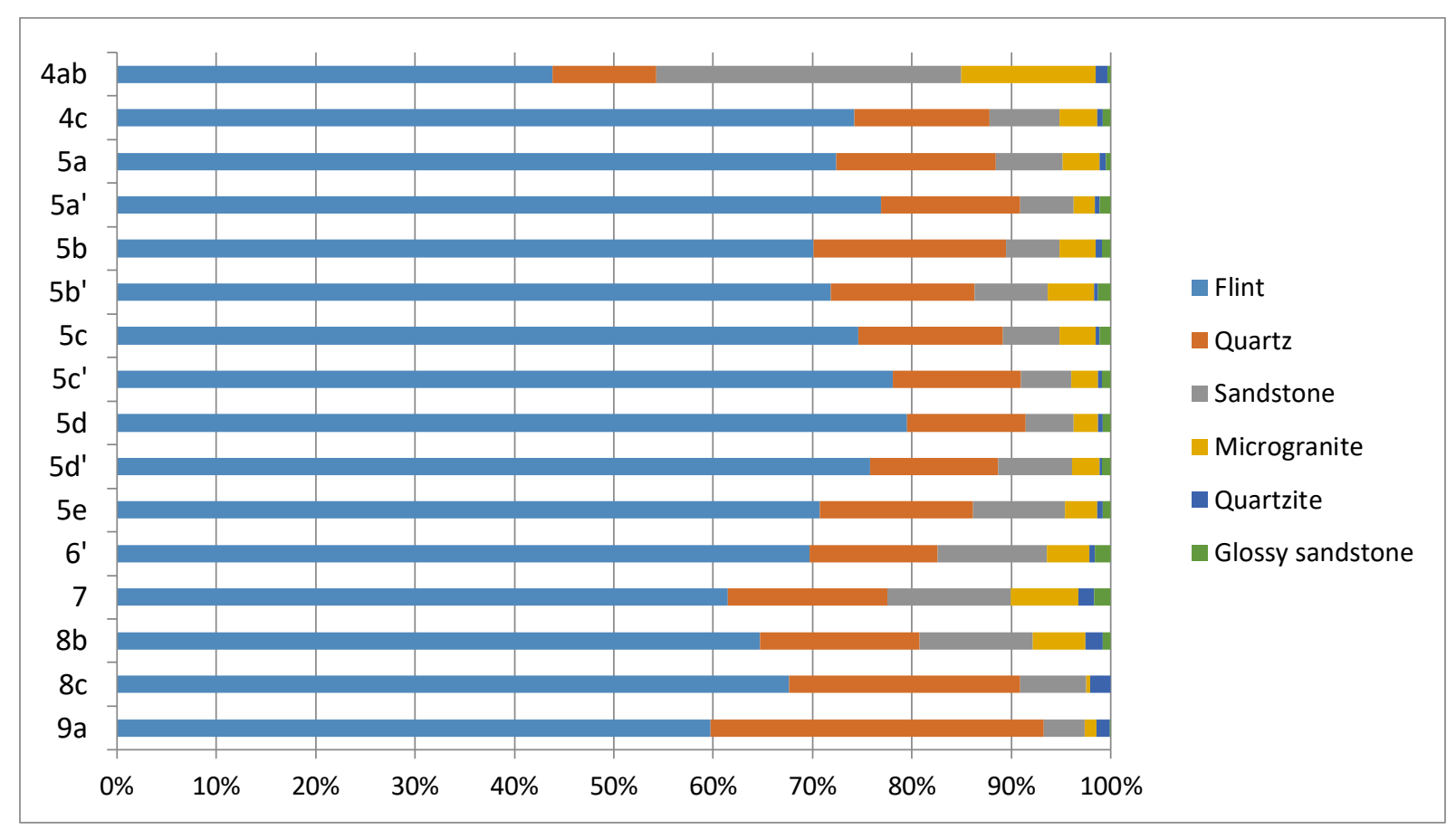

SOM Figure S2. Distribution of the different raw materials used in Menez-Dregan I according to each stratigraphical unit. 


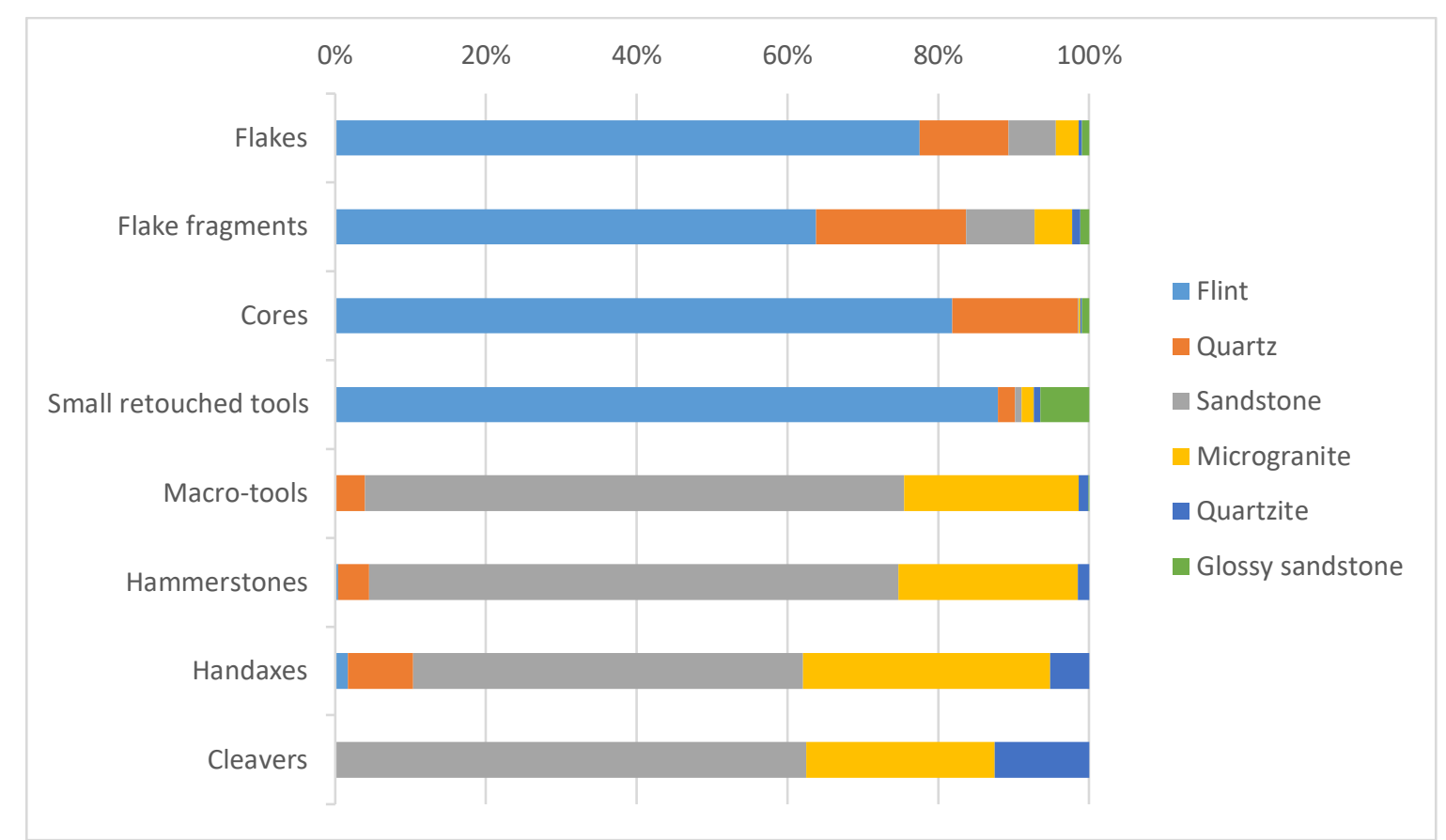

SOM Figure S3. Raw material distribution according to the main artifact types found at Menez-Dregan I. 


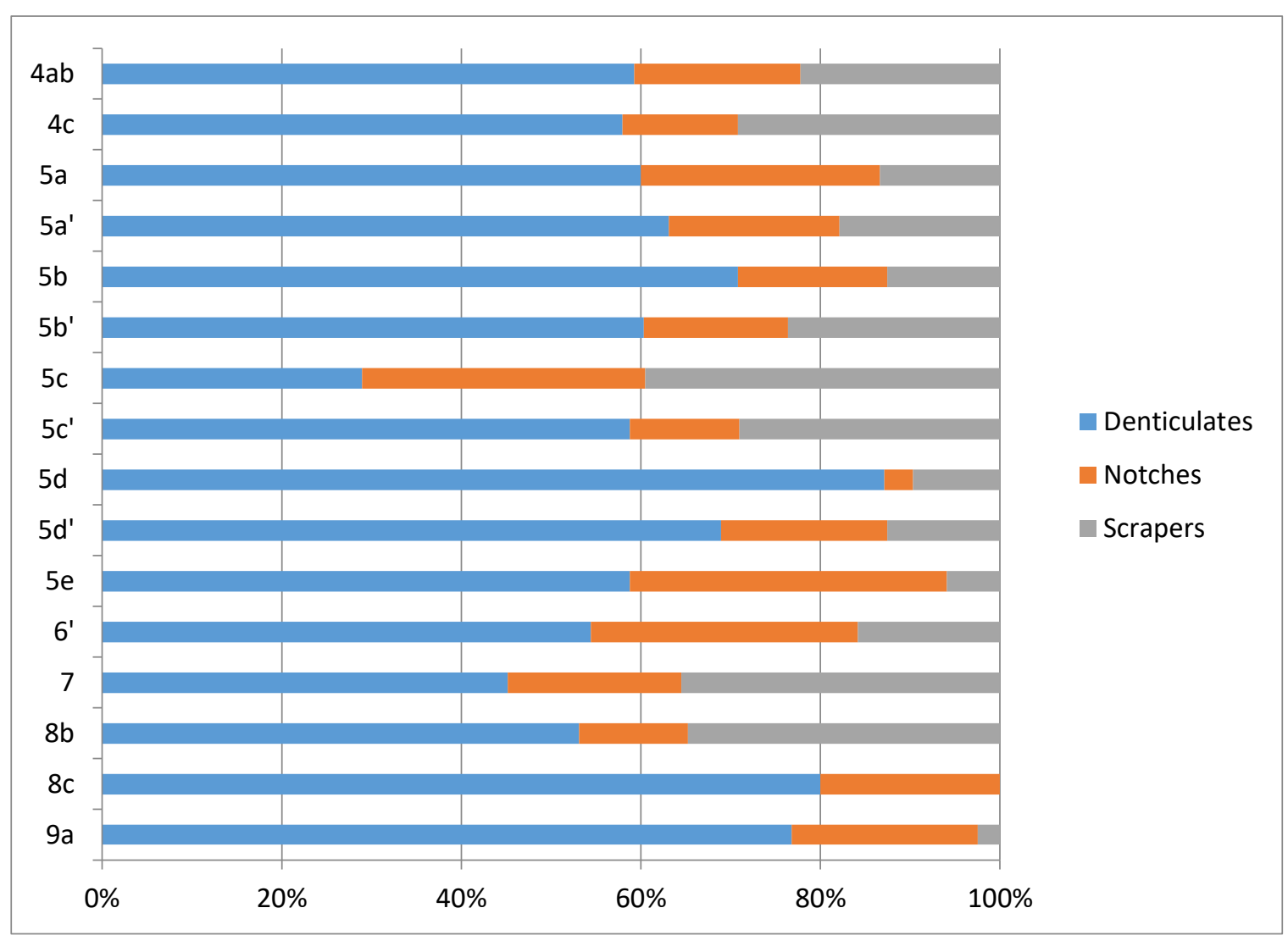

SOM Figure S4. Distribution of the three main types of small retouched tools (denticulates, notches and scrapers) according to each stratigraphical unit. 

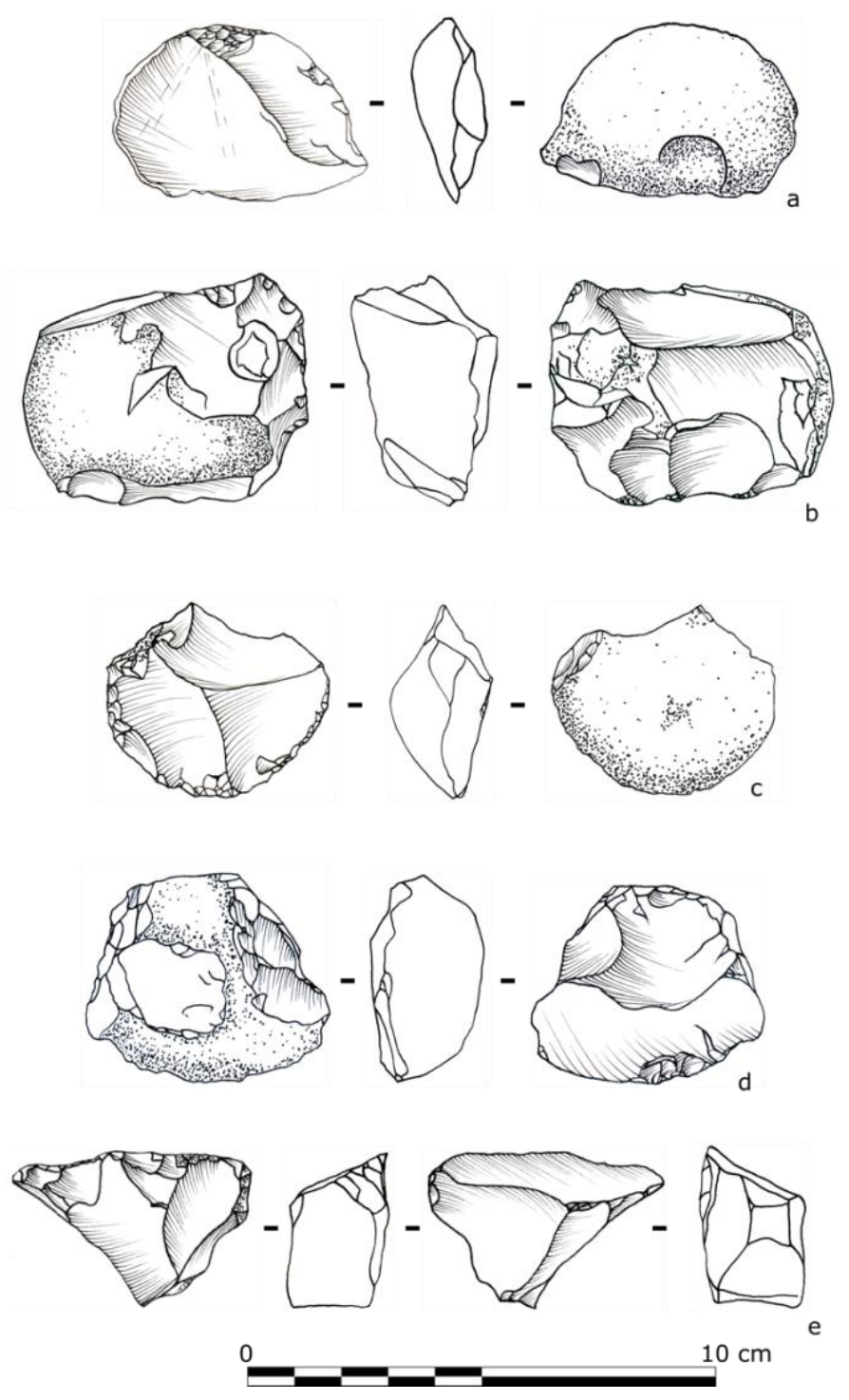

SOM Figure S5. Flint cores from SU 7: a) longitudinal Unipolar, b-c) centripetal, d) Transversal bipolar/Orthogonal, and e) Centripetal. Drawings: S. Guégan; CAD A.-L. Ravon. 

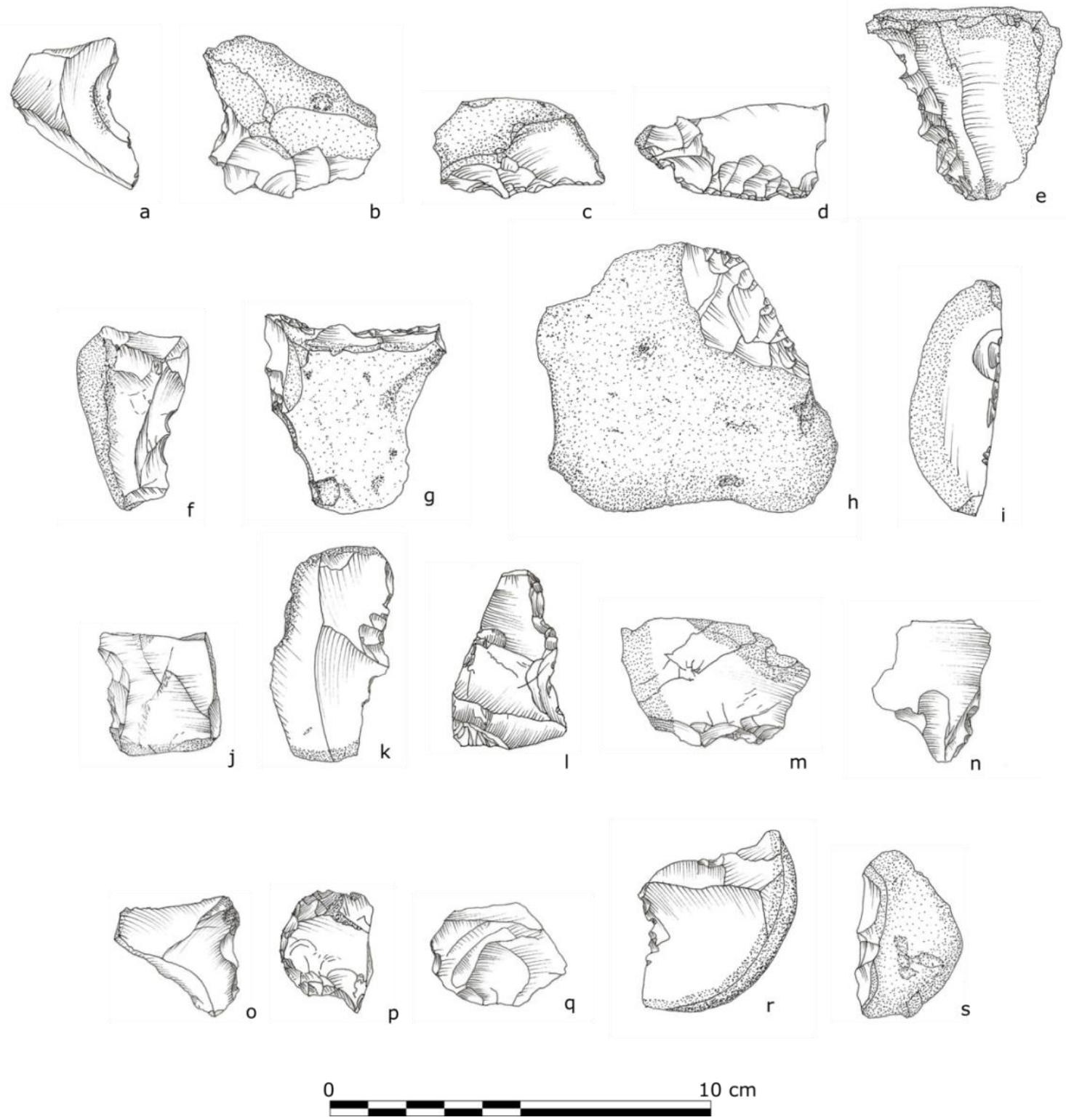

SOM Figure S6. Layer 5, small retouched tools made on flake-supports. US 5a' (a$\mathrm{d}), 5 \mathrm{~b}$ (e and f), 5b' (g and h), 5c (i-k), 5c' (l), 5d' (m-q), and $5 e$ ( $r$ and s). Drawings: L. Heccan, J. Guibert, J. Capdevielle, C. Gallou, J. Cadilhon and A.-L. Ravon; CAD A.-L. Ravon. 


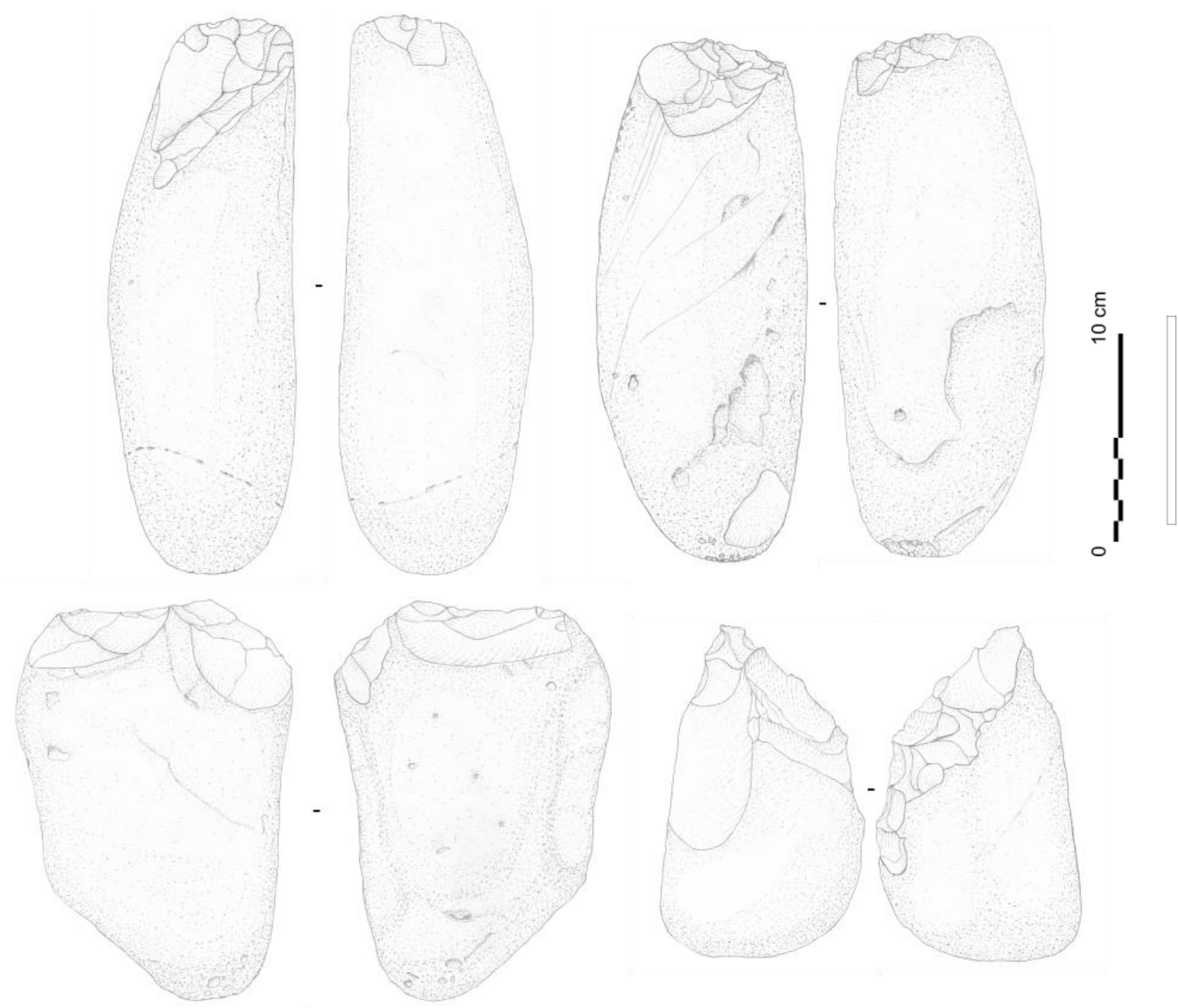

SOM Figure S7. Chopping tools from SU 4ab. Drawings: J. Guibert; CAD A.-L. Ravon. 


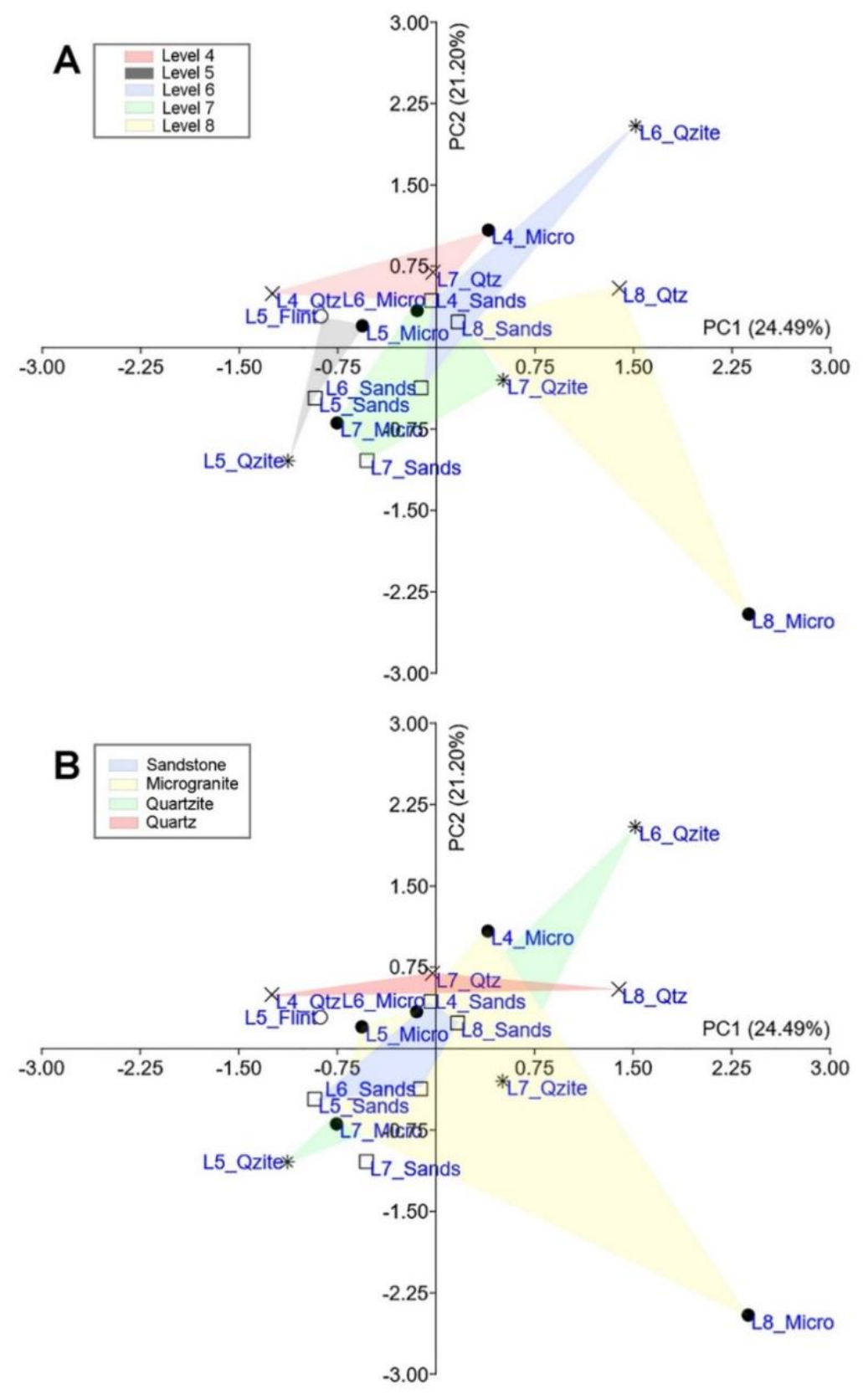

SOM Figure S8. Multivariate analysis of technological features of handaxes and cleavers from the Menez-Dregan I sequence $A$ ) by levels and $B$ ) by raw material. Abbreviations Fig. S8B: Qzite = quartzite; Micro = microgranite; Sands = sandstone; $\mathrm{Qtz}=$ quartz. Note Fig. S8B: the outliers are the materials with less representation (quartzite, quartz and flint, with only one piece each, as well as the microgranite from SU 8b, with only one piece). The remaining tools share a similar space and appear to be randomly distributed (SOM Fig. S8). 


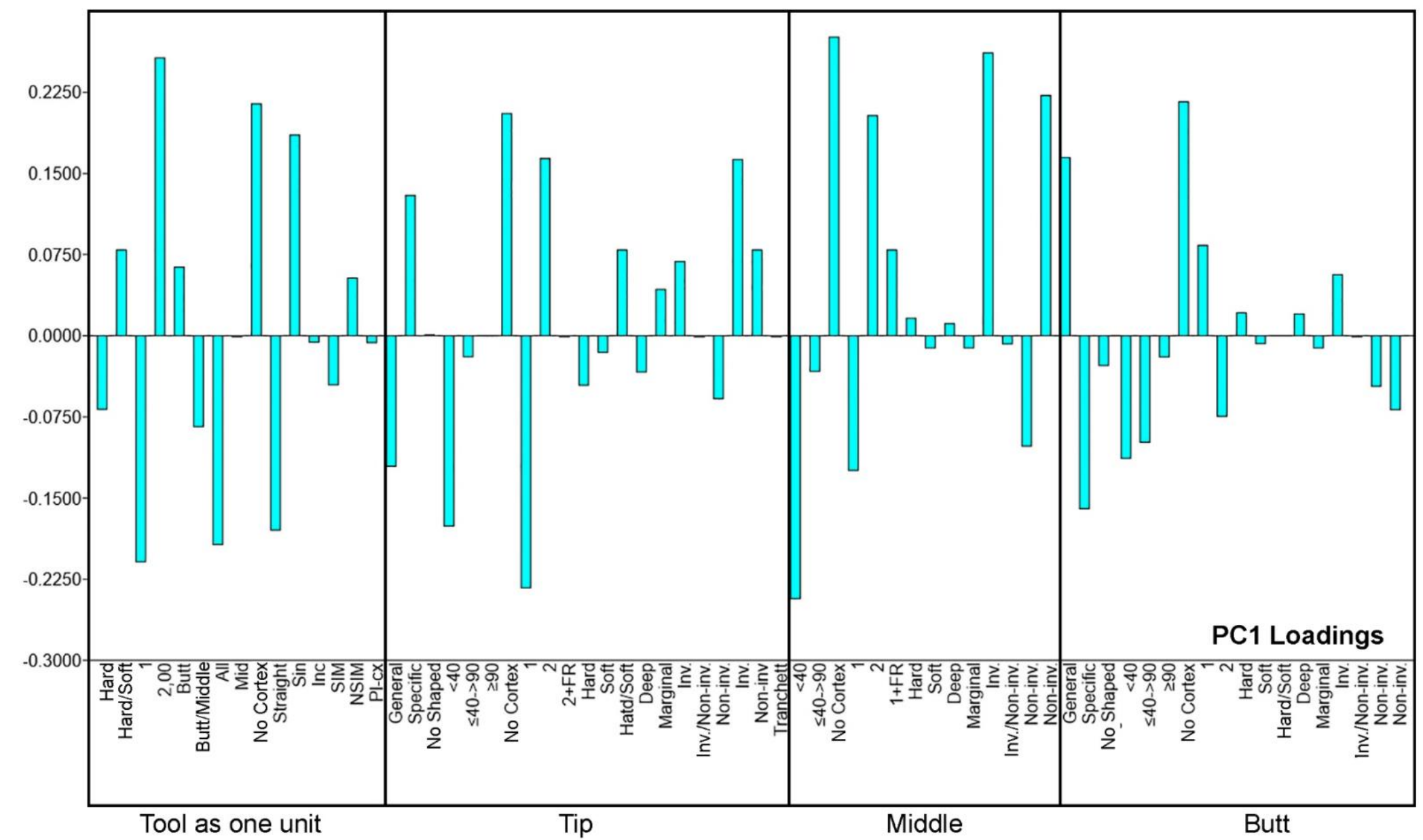

SOM Figure S9. Principal component (PC) 1 loadings of all the technological features included in the multivariate analyses, combining the information from SOM Tables S4-S7. 


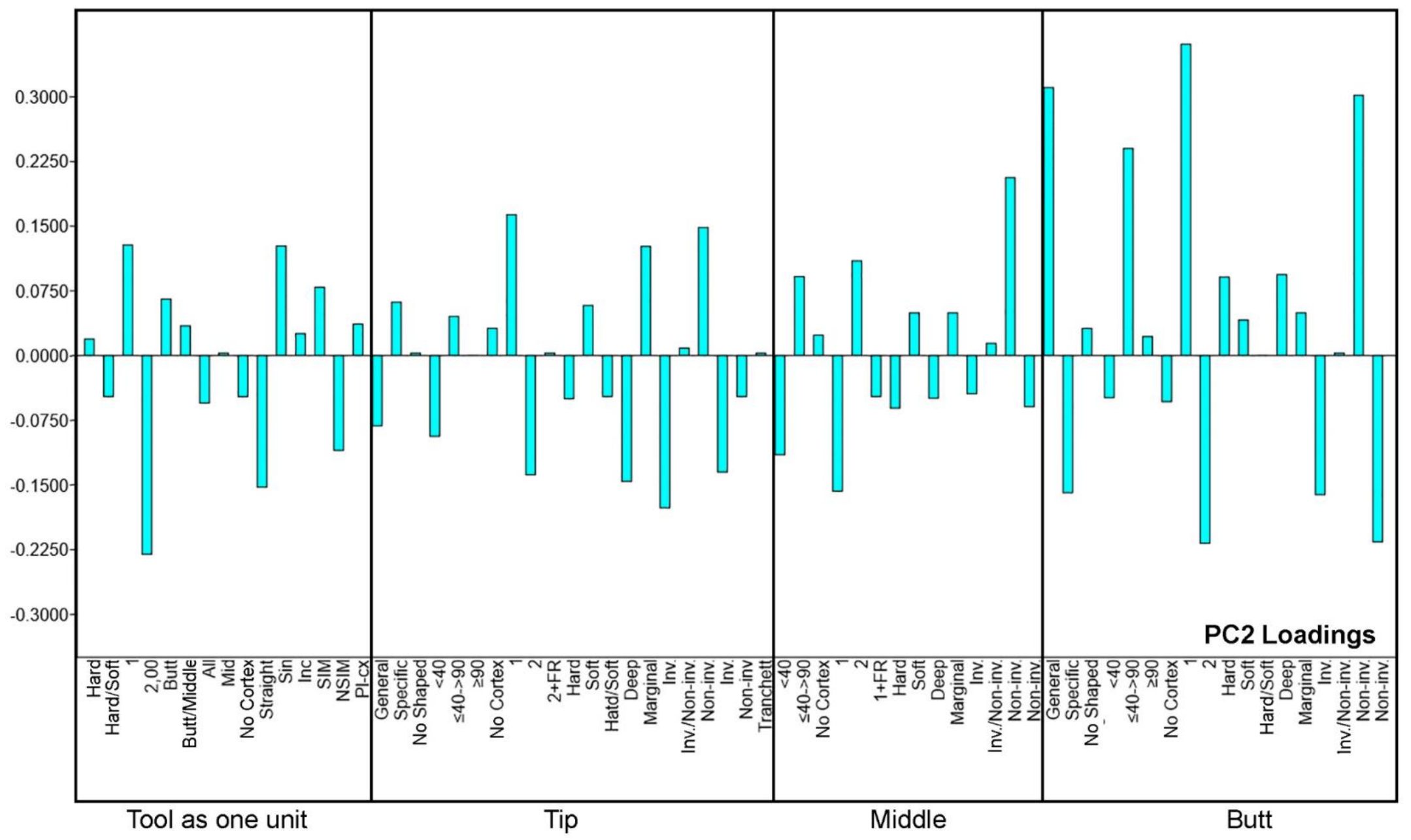

SOM Figure S10. Principal component (PC) 2 loadings of all the technological features included in the multivariate analyses, combining the information from SOM Tables S4-S7 


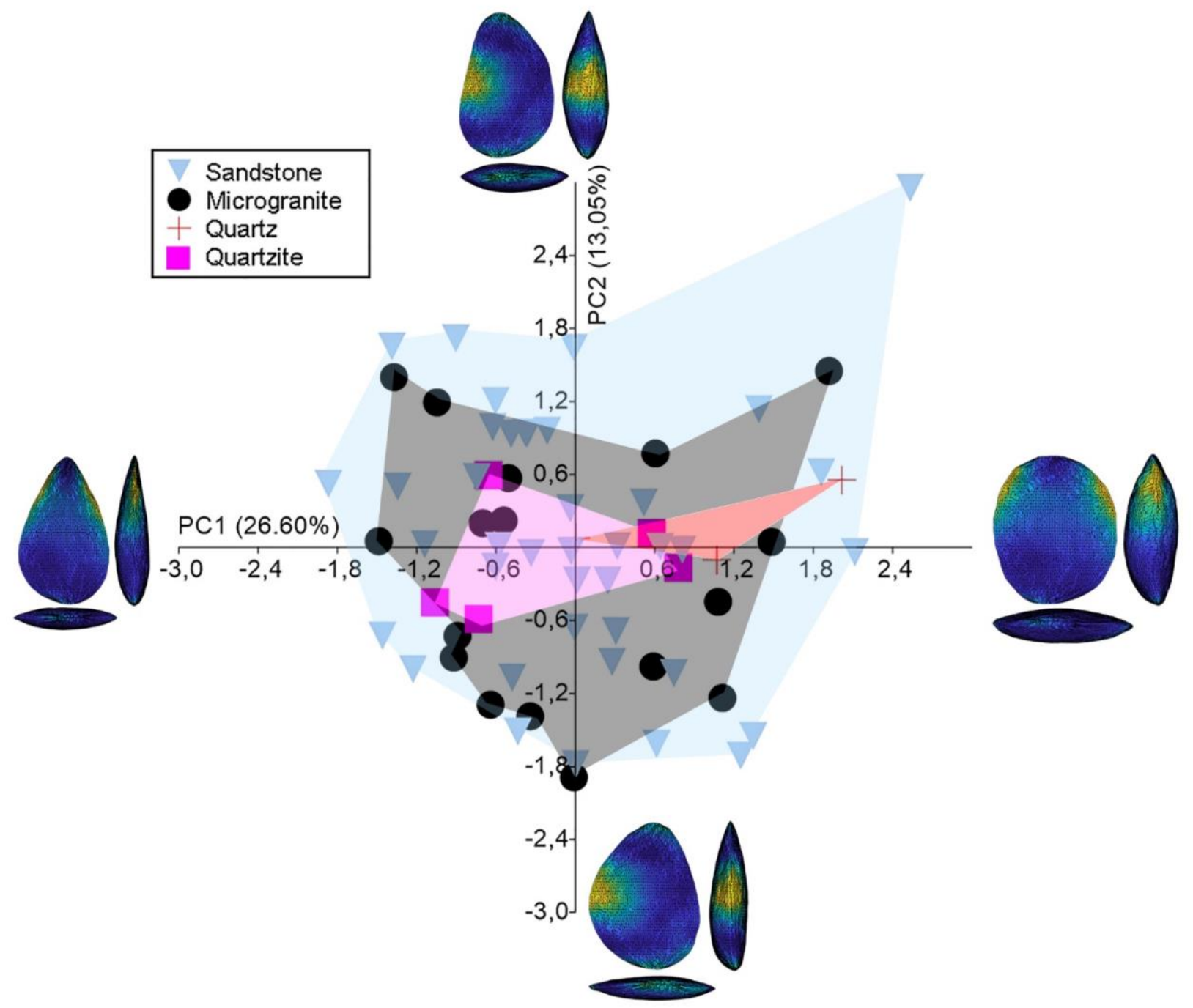

SOM Figure S11. Principal component (PC) scatter plots of handaxes and cleavers from MDI by raw materials. The Geometric Morphometrics (GM) has been applied to 3D models composed of 5000 semi-landmarks. Convex hulls indicate the range of points for a given group and the warps' tool represent the morphology. Color coding represents the landmarks that vary the most on the shape trend described on positive and negatives scores of PC1 and PC2 (from blue, less variability to yellow, highest variability). 


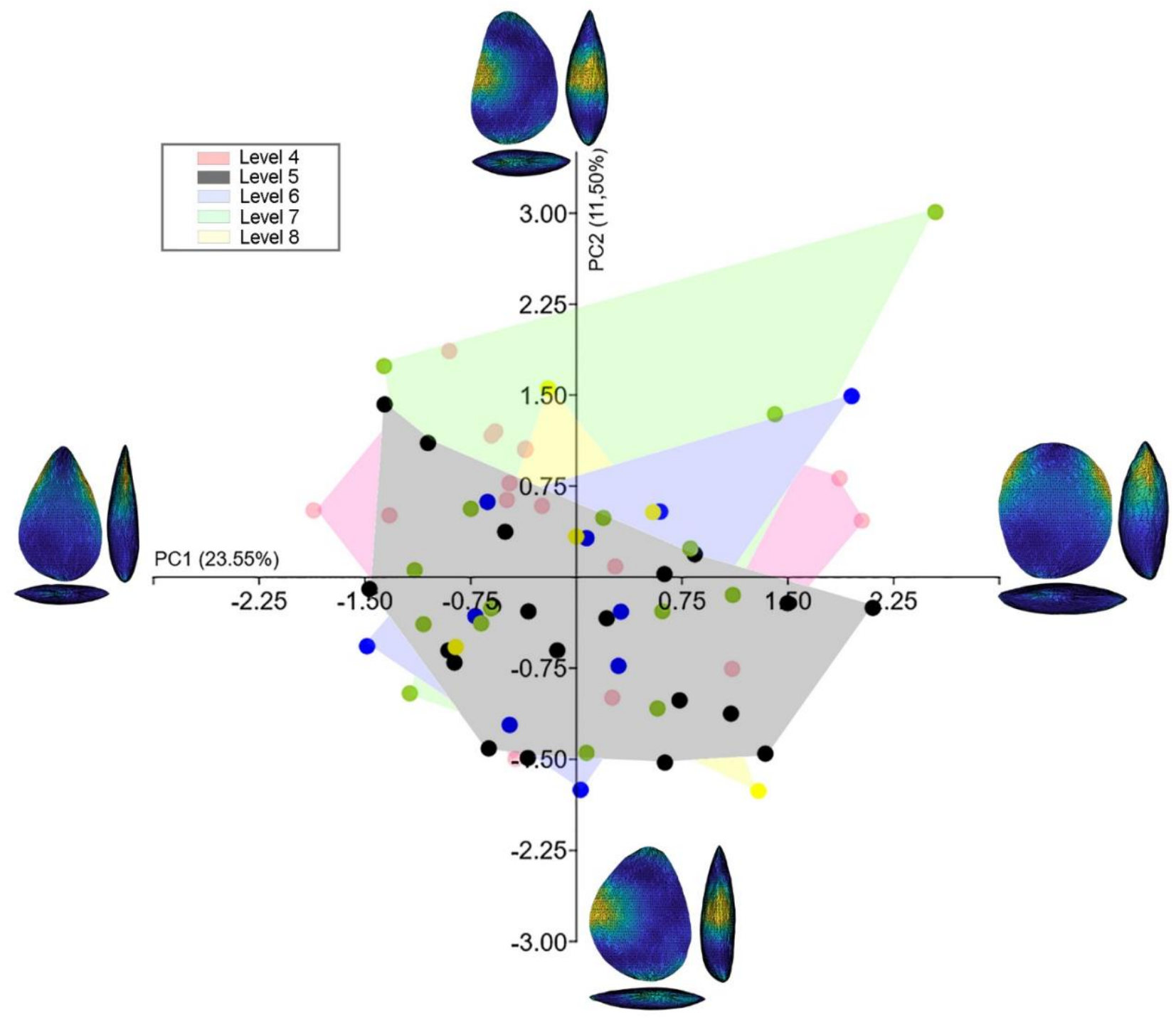

SOM Figure S12. Principal component (PC) scatter plots of handaxes and cleavers from MDI per layers. The Geometric Morphometrics (GM) has been applied to 3D models composed of 5000 semi-landmarks. Convex hulls indicate the range of points for a given group, and the warps' tool represent the morphology. Color coding represents the landmarks that vary the most on the shape trend described on positive and negatives scores of PC1 and PC2 (from blue, less variability to yellow, highest variability). 


\section{SOM Table S1}

Composition of the global lithic assemblage per raw material. Small chips and debris are not represented in this table.

\begin{tabular}{|c|c|c|c|c|c|c|c|c|c|c|}
\hline \multicolumn{2}{|l|}{ Type } & \multirow{2}{*}{$\begin{array}{c}\begin{array}{c}\text { Glossy } \\
\text { sandstone }\end{array} \\
79\end{array}$} & \multirow{2}{*}{$\begin{array}{c}\text { Quartz } \\
30\end{array}$} & \multirow{2}{*}{\begin{tabular}{|c|} 
Quartzite \\
10
\end{tabular}} & \multirow{2}{*}{$\begin{array}{c}\text { Microgranite } \\
17\end{array}$} & \multirow{2}{*}{$\begin{array}{c}\text { Sandstone } \\
15\end{array}$} & \multirow{2}{*}{$\begin{array}{c}\text { Flint } \\
1437\end{array}$} & \multicolumn{2}{|c|}{ Total } & $\%$ \\
\hline \multirow{5}{*}{$\begin{array}{l}\text { Small } \\
\text { retouched tools }\end{array}$} & Denticulates & & & & & & & 1588 & \multirow{5}{*}{2865} & \multirow{5}{*}{$1.9 \%$} \\
\hline & $\begin{array}{l}\text { Clactonian } \\
\text { notches }\end{array}$ & 6 & 5 & 1 & 0 & 1 & 133 & 146 & & \\
\hline & $\begin{array}{l}\text { Retouched } \\
\text { notches }\end{array}$ & 10 & 8 & 3 & 2 & 0 & 368 & 391 & & \\
\hline & Scrapers & 78 & 23 & 10 & 25 & 8 & 520 & 664 & & \\
\hline & Miscellaneous & 10 & 1 & 1 & 2 & 3 & 59 & 76 & & \\
\hline \multicolumn{2}{|l|}{ Cores } & 157 & 2942 & 45 & 31 & 28 & 14481 & \multicolumn{2}{|c|}{17684} & $11.5 \%$ \\
\hline \multicolumn{2}{|l|}{ Flakes } & 769 & 9806 & 398 & 2505 & 5220 & 64501 & \multicolumn{2}{|c|}{83199} & $54 \%$ \\
\hline \multicolumn{2}{|l|}{ Flake fragments } & 491 & 8524 & 451 & 2153 & 3857 & 27221 & \multicolumn{2}{|c|}{42697} & $27.7 \%$ \\
\hline \multicolumn{2}{|c|}{ Miscellaneous fragments } & 13 & 622 & 38 & 55 & 241 & 837 & \multicolumn{2}{|c|}{1806} & $1.2 \%$ \\
\hline \multirow{4}{*}{ Choppers } & Distal & 0 & 16 & 6 & 98 & 670 & 0 & 790 & \multirow{4}{*}{1150} & \multirow{4}{*}{$0.7 \%$} \\
\hline & Lateral & 0 & 2 & 2 & 20 & 68 & 0 & 92 & & \\
\hline & Latero-distal & 0 & 7 & 1 & 33 & 195 & 0 & 236 & & \\
\hline & Double & 0 & 0 & 0 & 6 & 26 & 0 & 32 & & \\
\hline \multicolumn{2}{|l|}{ Chopping-tools } & 0 & 8 & 2 & 54 & 157 & 0 & \multicolumn{2}{|c|}{221} & $0.1 \%$ \\
\hline \multicolumn{2}{|l|}{ Hammerstones } & 0 & 93 & 33 & 536 & 1578 & 8 & \multicolumn{2}{|c|}{2248} & $1.5 \%$ \\
\hline \multicolumn{2}{|l|}{ Anvils } & 0 & 2 & 1 & 19 & 33 & 0 & \multicolumn{2}{|c|}{55} & $0 \%$ \\
\hline \multicolumn{2}{|c|}{ Pebbles with single removals } & 0 & 3 & 2 & 19 & 73 & 0 & & 97 & $0.1 \%$ \\
\hline
\end{tabular}




\begin{tabular}{|c|c|c|c|c|c|c|c|c|}
\hline Undetermined & 0 & 14 & 8 & 111 & 307 & 0 & 440 & $0.3 \%$ \\
\hline Flakes or flake fragments $>10 \mathrm{~cm}$ & 1 & 65 & 15 & 293 & 634 & 0 & 1008 & $0.7 \%$ \\
\hline Pebble/cobble fragments & 0 & 11 & 7 & 133 & 328 & 2 & 481 & $0.3 \%$ \\
\hline Miscellaneous macro-tools & 1 & 15 & 3 & 55 & 80 & 0 & 154 & $0.1 \%$ \\
\hline Handaxes/cleavers & 0 & 3 & 6 & 21 & 35 & 1 & 66 & $0 \%$ \\
\hline Total & 1615 & 22200 & 1043 & 6187 & 13557 & 109568 & 154170 & $100 \%$ \\
\hline$\%$ & $1 \%$ & $14.4 \%$ & $0.7 \%$ & $4 \%$ & $8.8 \%$ & $71.1 \%$ & \multicolumn{2}{|c|}{$100 \%$} \\
\hline
\end{tabular}


SOM Table S2

Presence of handaxes and cleavers by Layers.

\begin{tabular}{|c|c|c|c|c|c|}
\hline \multirow{2}{*}{ Layer/tool type } & \multicolumn{2}{|c|}{ Handaxes } & \multicolumn{2}{|c|}{ Cleavers } & \multirow{2}{*}{ Total } \\
\cline { 2 - 5 } & $n$ & $\%$ & $n$ & $\%$ & \\
\hline Layer 4 & 14 & 87.50 & 2 & 12.50 & 16 \\
\hline Layer 5 & 18 & 90.00 & 2 & 10.00 & 20 \\
\hline Layer 6 & 10 & 100.00 & - & - & 10 \\
\hline Layer 7 & 12 & 80.00 & 3 & 20.00 & 15 \\
\hline Layer 8 & 4 & 80.00 & 1 & 20.00 & 5 \\
\hline Total & 58 & 87.88 & 8 & 12.12 & 66 \\
\hline
\end{tabular}




\section{SOM Table S3}

Handaxes and cleavers by type of blank.

\begin{tabular}{|c|c|c|c|c|c|c|c|}
\hline \multirow{2}{*}{ Layer/Blank type } & \multicolumn{2}{|c|}{ Cobble } & \multicolumn{2}{|c|}{ Flake } & \multicolumn{2}{|c|}{ Unknown } & \multirow{2}{*}{ Tota } \\
\hline & $(n)$ & $\%$ & $(n)$ & $\%$ & $(n)$ & $\%$ & \\
\hline Layer 4 & 3 & 18.75 & 13 & 81.25 & - & - & 16 \\
\hline Layer 5 & 2 & 10.00 & 18 & 90.00 & - & - & 20 \\
\hline Layer 6 & 1 & 10.00 & 9 & 90.00 & - & - & 10 \\
\hline Layer 7 & 1 & 6.67 & 12 & 80.00 & 2 & 13.33 & 15 \\
\hline Layer 8 & 0 & 0.00 & 3 & 60.00 & 2 & 40.00 & 5 \\
\hline Total & 7 & 10.61 & 55 & 83.33 & 4 & 6.06 & 66 \\
\hline
\end{tabular}




\section{SOM Table S4}

Technological features considered in an analysis of each tool as one unit

\begin{tabular}{|c|c|c|c|c|c|c|c|c|c|c|c|c|c|c|c|c|c|c|c|c|c|}
\hline \multirow{2}{*}{ Layer } & \multirow{2}{*}{ Blank } & \multicolumn{2}{|c|}{ UF } & \multicolumn{2}{|r|}{$\mathrm{BF}$} & \multicolumn{2}{|c|}{ Soft } & \multicolumn{2}{|c|}{ Hard } & \multicolumn{2}{|c|}{ Hard/soft } & \multicolumn{2}{|r|}{1} & \multicolumn{2}{|r|}{2} & \multicolumn{2}{|c|}{ Butt } & \multicolumn{2}{|c|}{ Butt/middle } & \multicolumn{2}{|c|}{ All } \\
\hline & & (n) & $\%$ & (n) & $\%$ & (n) & $\%$ & (n) & $\%$ & (n) & $\%$ & $(n)$ & $\%$ & (n) & $\%$ & (n) & $\%$ & (n) & $\%$ & (n) & $\%$ \\
\hline \multirow{3}{*}{ L4 } & Cobble & & 0.00 & 3 & 100.00 & & 0.00 & 3 & 100.00 & & 0.00 & 1 & 33.33 & 2 & 66.67 & & 0.00 & 1 & 33.33 & 2 & 66.67 \\
\hline & Flake & & 0.00 & 13 & 100.00 & & 0.00 & 12 & 92.31 & & 0.00 & 6 & 46.15 & 7 & 53.85 & 2 & 15.38 & 10 & 76.92 & 1 & 7.69 \\
\hline & Unknown & & & & & & & & & & & & & & & & & & & & \\
\hline \multirow{3}{*}{ L5 } & Cobble & & 0.00 & 2 & 100.00 & & 0.00 & 2 & 100.00 & & 0.00 & 2 & 100.00 & & 0.00 & & 0.00 & 2 & 100.00 & & 0.00 \\
\hline & Flake & & 0.00 & 18 & 100.00 & & 0.00 & 18 & 100.00 & & 0.00 & 17 & 94.44 & 1 & 5.56 & & 0.00 & 11 & 61.11 & 6 & 33.33 \\
\hline & Unknown & & & & & & & & & & & & & & & & & & & & \\
\hline \multirow{3}{*}{ L6 } & Cobble & & 0.00 & 1 & 100.00 & & 0.00 & 1 & 100.00 & & 0.00 & & 0.00 & 1 & 100.00 & & 0.00 & 1 & 100.00 & & 0.00 \\
\hline & Flake & & 0.00 & 9 & 100.00 & & 0.00 & 9 & 100.00 & & 0.00 & 8 & 88.89 & 1 & 11.11 & & 0.00 & 6 & 66.67 & & 0.00 \\
\hline & Unknown & & & & & & & & & & & & & & & & & & & & \\
\hline \multirow{3}{*}{ L7 } & Cobble & & 0.00 & 1 & 100.00 & & 0.00 & 1 & 100.00 & & 0.00 & 1 & 100.00 & & 0.00 & & 0.00 & & 0.00 & 1 & 100.00 \\
\hline & Flake & & 0.00 & 12 & 100.00 & & 0.00 & 9 & 75.00 & & 0.00 & & 0.00 & & 0.00 & & 0.00 & 4 & 33.33 & 7 & 58.33 \\
\hline & Unknown & & 0.00 & 2 & 100.00 & & 0.00 & 1 & 50.00 & 1 & 50.00 & & 0.00 & 2 & 100.00 & & 0.00 & & 0.00 & & 0.00 \\
\hline \multirow{3}{*}{ L8 } & Cobble & & & & & & & & & & & & & & & & & & & & \\
\hline & Flake & & 0.00 & 3 & 100.00 & & 0.00 & 3 & 100.00 & & 0.00 & 3 & 100.00 & & 0.00 & 1 & 33.33 & 1 & 33.33 & 1 & 33.33 \\
\hline & Unknown & & 0.00 & 2 & 100.00 & & 0.00 & 2 & 100.00 & & 0.00 & 1 & 50.00 & 1 & 50.00 & 1 & 50.00 & & 0.00 & & 0.00 \\
\hline
\end{tabular}

\begin{tabular}{|c|c|c|c|c|c|c|c|c|c|c|c|c|c|c|c|c|c|c|}
\hline \multirow{2}{*}{ Layer } & \multirow{2}{*}{ Blank } & \multicolumn{2}{|c|}{ Mid } & \multicolumn{2}{|c|}{ NC } & \multicolumn{2}{|c|}{ Straight } & \multicolumn{2}{|c|}{ Sin } & \multicolumn{2}{|c|}{ Inc } & \multicolumn{2}{|c|}{ SIM } & \multicolumn{2}{|c|}{ NSIM } & \multicolumn{2}{|c|}{ PI-cx } & \multirow{2}{*}{ TOTAL } \\
\hline & & $(n)$ & $\%$ & (n) & $\%$ & (n) & $\%$ & $(n)$ & $\%$ & (n) & $\%$ & $(n)$ & $\%$ & (n) & $\%$ & (n) & $\%$ & \\
\hline \multirow{3}{*}{ L4 } & Cobble & & 0.00 & & 0.00 & 1 & 33.33 & 2 & 66.67 & & 0.00 & 1 & 33.33 & 2 & 66.67 & & 0.00 & 3 \\
\hline & Flake & & 0.00 & & 0.00 & 5 & 38.46 & 5 & 38.46 & 3 & 23.08 & 5 & 38.46 & 4 & 30.77 & 6 & 46.15 & 13 \\
\hline & Unknown & & & & & & & & & & & & & & & & & \\
\hline \multirow{3}{*}{ L5 } & Cobble & & 0.00 & & 0.00 & & 0.00 & 2 & 100.00 & & 0.00 & 1 & 50.00 & 1 & 50.00 & & 0.00 & 2 \\
\hline & Flake & & 0.00 & 1 & 5.56 & 7 & 38.89 & 10 & 55.56 & 1 & 5.56 & 7 & 38.89 & 8 & 44.44 & 3 & 16.67 & 18 \\
\hline & Unknown & & & & & & & & & & & & & & & & & \\
\hline
\end{tabular}




\begin{tabular}{|c|c|c|c|c|c|c|c|c|c|c|c|c|c|c|c|c|c|c|}
\hline \multirow{3}{*}{ L6 } & Cobble & & 0.00 & & 0.00 & 1 & 100.00 & & 0.00 & & 0.00 & & 0.00 & 1 & 100.00 & & 0.00 & 1 \\
\hline & Flake & 1 & 11.11 & 2 & 22.22 & 6 & 66.67 & 2 & 22.22 & 1 & 11.11 & 2 & 22.22 & 6 & 66.67 & 1 & 11.11 & 9 \\
\hline & Unknown & & & & & & & & & & & & & & & & & \\
\hline \multirow{3}{*}{ L7 } & Cobble & & 0.00 & & 0.00 & 1 & 100.00 & & 0.00 & & 0.00 & & 0.00 & 1 & 100.00 & & 0.00 & 1 \\
\hline & Flake & & 0.00 & 1 & 8.33 & 5 & 41.67 & 6 & 50.00 & 1 & 8.33 & & 0.00 & 12 & 100.00 & & 0.00 & 12 \\
\hline & Unknown & & 0.00 & 2 & 100.00 & & 0.00 & 2 & 100.00 & & 0.00 & & 0.00 & 2 & 100.00 & & 0.00 & 2 \\
\hline \multirow{3}{*}{ L8 } & Cobble & & & & & & & & & & & & & & & & & \\
\hline & Flake & & 0.00 & & 0.00 & 3 & 100.00 & & 0.00 & & 0.00 & & 0.00 & 3 & 100.00 & & 0.00 & 3 \\
\hline & Unknown & & 0.00 & 1 & 50.00 & & 0.00 & 2 & 100.00 & & 0.00 & & 0.00 & 2 & 100.00 & & 0.00 & 2 \\
\hline
\end{tabular}

Abbreviations: UF = unifacial; $\mathrm{BF}=$ bifacial; Hard = hard percussion; Soft $=$ soft percussion; Hard/soft $=$ combined; $1=$ one removal series; $2=$ two removal series; Butt = cortex in butts; Butt/middle = cortex in butts and mid parts; All = cortex in the whole instrument.; Mid = cortex in the mid parts; NC = no cortex; Straight = straight edges; $\operatorname{Sin}=$ sinuous edges; Inc, incurved edges; $\mathrm{SIM}=$ symmetric profile; NSIM = nonsymmetric profile; $\mathrm{Pl}-\mathrm{cx}=$ plano-convex profile. 


\section{SOM Table S5}

Technological features considered in the analysis of tip of tools.

\begin{tabular}{|c|c|c|c|c|c|c|c|c|c|c|c|c|c|c|c|c|c|c|c|c|c|}
\hline \multirow{2}{*}{ Layer } & \multirow{2}{*}{ Blank } & \multicolumn{2}{|c|}{ GR_shap. } & \multicolumn{2}{|c|}{ SPC_shap. } & \multicolumn{2}{|c|}{ NS } & \multicolumn{2}{|r|}{$<40$} & \multicolumn{2}{|c|}{$\leq 40->90$} & \multicolumn{2}{|r|}{$\mathrm{NC}$} & \multicolumn{2}{|r|}{1} & \multicolumn{2}{|r|}{2} & \multicolumn{2}{|c|}{$1+\mathrm{FR}$} & \multicolumn{2}{|c|}{$2+F R$} \\
\hline & & $n$ & $\%$ & $n$ & $\%$ & $n$ & $\%$ & $n$ & $\%$ & $n$ & $\%$ & $n$ & $\%$ & $n$ & $\%$ & $n$ & $\%$ & $n$ & $\%$ & $n$ & $\%$ \\
\hline \multirow{3}{*}{ L4 } & Cobble & 3 & 100.00 & & 0.00 & & 0.00 & 1 & 33.33 & & 0.00 & 2 & 66.67 & 2 & 66.67 & 1 & 33.33 & & 0.00 & & 0.00 \\
\hline & Flake & 12 & 92.31 & & 0.00 & 1 & 7.69 & 1 & 7.69 & 1 & 7.69 & 11 & 84.62 & 6 & 46.15 & 6 & 46.15 & & 0.00 & & 0.00 \\
\hline & Unknown & & & & & & & & & & & & & & & & & & & & \\
\hline \multirow{3}{*}{ L5 } & Cobble & 2 & 100.00 & & 0.00 & & 0.00 & & 0.00 & & 0.00 & 2 & 100.00 & 2 & 100.00 & & 0.00 & & 0.00 & & 0.00 \\
\hline & Flake & 15 & 83.33 & & 0.00 & & 0.00 & 4 & 22.22 & 1 & 5.56 & 10 & 55.56 & 14 & 77.78 & 1 & 5.56 & & 0.00 & & 0.00 \\
\hline & Unknown & & & & & & & & & & & & & & & & & & & & \\
\hline \multirow{3}{*}{ L6 } & Cobble & 1 & 100.00 & & 0.00 & & 0.00 & & 0.00 & & 0.00 & 1 & 100.00 & & 0.00 & 1 & 100.00 & & 0.00 & & 0.00 \\
\hline & Flake & 9 & 100.00 & & 0.00 & & 0.00 & 1 & 11.11 & 1 & 11.11 & 7 & 77.78 & 6 & 66.67 & 2 & 22.22 & & 0.00 & 1 & 11.11 \\
\hline & Unknown & & & & & & & & & & & & & & & & & & & & \\
\hline \multirow{3}{*}{ L7 } & Cobble & 1 & 100.00 & & 0.00 & & 0.00 & 1 & 100.00 & & 0.00 & & 0.00 & 1 & 100.00 & & 0.00 & & 0.00 & & 0.00 \\
\hline & Flake & 10 & 83.33 & 2 & 16.67 & & 0.00 & 3 & 25.00 & 4 & 33.33 & 5 & 41.67 & 11 & 91.67 & 1 & 8.33 & & 0.00 & & 0.00 \\
\hline & Unknown & 1 & 50.00 & 1 & 50.00 & & 0.00 & & 0.00 & & 0.00 & 2 & 100.00 & & 0.00 & 1 & 50.00 & 1 & 50.00 & & 0.00 \\
\hline \multirow{3}{*}{ L8 } & Cobble & & & & & & & & & & & & & & & & & & & & \\
\hline & Flake & 1 & 33.33 & 2 & 66.67 & & 0.00 & 1 & 33.33 & & 0.00 & 2 & 66.67 & 2 & 66.67 & 1 & 33.33 & & 0.00 & & 0.00 \\
\hline & Unknown & 1 & 50.00 & 1 & 50.00 & & 0.00 & & 0.00 & & 0.00 & 2 & 100.00 & 1 & 50.00 & 1 & 50.00 & & 0.00 & & 0.00 \\
\hline
\end{tabular}

\begin{tabular}{|c|c|c|c|c|c|c|c|c|c|c|c|c|c|c|c|c|c|c|c|c|c|c|c|c|}
\hline \multirow{2}{*}{ Layer } & \multirow{2}{*}{ Blank } & \multicolumn{2}{|c|}{ Hard } & \multicolumn{2}{|c|}{ Soft } & \multicolumn{2}{|c|}{$\mathrm{H} / \mathrm{S}$} & \multicolumn{2}{|c|}{ Deep } & \multicolumn{2}{|c|}{ Marginal } & \multicolumn{2}{|c|}{ 1_Inv. } & \multicolumn{2}{|c|}{ Inv./N inv } & \multicolumn{2}{|c|}{ 1_Non-inv. } & \multicolumn{2}{|c|}{ 2_Non-inv. } & \multicolumn{2}{|c|}{ FR. Non-inv } & \multicolumn{2}{|c|}{ FR_Tranchet } & \multirow{2}{*}{ Total } \\
\hline & & $n$ & $\%$ & $n$ & $\%$ & $n$ & $\%$ & $n$ & $\%$ & $n$ & $\%$ & $n$ & $\%$ & $n$ & $\%$ & $n$ & $\%$ & $n$ & $\%$ & $n$ & $\%$ & $n$ & $\%$ & \\
\hline \multirow{3}{*}{ L4 } & Cobble & 3 & 100.00 & & 0.00 & & 0.00 & 3 & 100.00 & & 0.00 & 3 & 100.00 & & 0.00 & & 0.00 & 1 & 33.33 & & 0.00 & & 0.00 & 3 \\
\hline & Flake & 12 & 92.31 & & 0.00 & & 0.00 & 12 & 92.31 & & 0.00 & 9 & 69.23 & 1 & 7.69 & 2 & 15.38 & 6 & 46.15 & & 0.00 & & 0.00 & 13 \\
\hline & Unknown & & & & & & & & & & & & & & & & & & & & & & & \\
\hline L5 & Cobble & 2 & 100.00 & & 0.00 & & 0.00 & 2 & 100.00 & & 0.00 & 2 & 100.00 & & 0.00 & & 0.00 & & 0.00 & & 0.00 & & 0.00 & 2 \\
\hline
\end{tabular}




\begin{tabular}{|c|c|c|c|c|c|c|c|c|c|c|c|c|c|c|c|c|c|c|c|c|c|c|c|c|}
\hline & Flake & 15 & 83.33 & & 0.00 & & 0.00 & 15 & 83.33 & & 0.00 & 7 & 38.89 & & 0.00 & 8 & 44.44 & 1 & 5.56 & & 0.00 & & 0.00 & 18 \\
\hline & Unknown & & & & & & & & & & & & & & & & & & & & & & & \\
\hline \multirow{3}{*}{ L6 } & Cobble & 1 & 100.00 & & 0.00 & & 0.00 & 1 & 100.00 & & 0.00 & 1 & 100.00 & & 0.00 & & 0.00 & 1 & 100.00 & & 0.00 & & 0.00 & 1 \\
\hline & Flake & 8 & 88.89 & & 0.00 & & 0.00 & 9 & 100.00 & & 0.00 & 5 & 55.56 & 2 & 22.22 & 2 & 22.22 & 3 & 33.33 & & 0.00 & 1 & 11.11 & 9 \\
\hline & Unknown & & & & & & & & & & & & & & & & & & & & & & & \\
\hline \multirow{3}{*}{ L7 } & Cobble & 1 & 100.00 & & 0.00 & & 0.00 & 1 & 100.00 & & 0.00 & 1 & 100.00 & & 0.00 & & 0.00 & & 0.00 & & 0.00 & & 0.00 & 1 \\
\hline & Flake & 7 & 58.33 & 3 & 25.00 & & 0.00 & 8 & 66.67 & 4 & 33.33 & 5 & 41.67 & & 0.00 & 7 & 58.33 & 1 & 8.33 & & 0.00 & & 0.00 & 12 \\
\hline & Unknown & 1 & 50.00 & & 0.00 & 1 & 50.00 & 2 & 100.00 & & 0.00 & 2 & 100.00 & & 0.00 & & 0.00 & 1 & 50.00 & 1 & 50.00 & & 0.00 & 2 \\
\hline \multirow{3}{*}{ L8 } & Cobble & & & & & & & & & & & & & & & & & & & & & & & \\
\hline & Flake & 2 & 66.67 & 1 & 33.33 & & 0.00 & 1 & 33.33 & 2 & 66.67 & 2 & 66.67 & & 0.00 & 1 & 33.33 & 1 & 33.33 & & 0.00 & & 0.00 & 3 \\
\hline & Unknown & 2 & 100.00 & & 0.00 & & 0.00 & 1 & 50.00 & 1 & 50.00 & 2 & 100.00 & & 0.00 & & 0.00 & 1 & 50.00 & & 0.00 & & 0.00 & 2 \\
\hline
\end{tabular}

Abbreviations: GR_shap. = general shaping; SPC_shap. = specific shaping; NS = not shaped; Cortex remaining $(<40 ; \leq 40->90) ; \mathrm{NC}=\mathrm{no}$

cortex; 1 = one removal series; 2 = two removal series; $1+F R=$ one plus final retouch; $2+F R$, two plus final retouch; Hard = hard percussion; Soft = soft percussion; $\mathrm{H} / \mathrm{S}=$ combined; Deep = deep effect on edges; Marginal = marginal effect on edges; 1 Inv. = first invasive removal

series; Inv./N inv = combined; 1 Non-inv. = first non-invasive removal series; 2_Non-inv. = second non-invasive removal series; FR. Non-inv. = non-invasive final retouch; FR_ Tranchet $=$ distal tranchet final retouch. 


\section{SOM Table S6}

Technological features considered in an analysis of mid parts of tools.

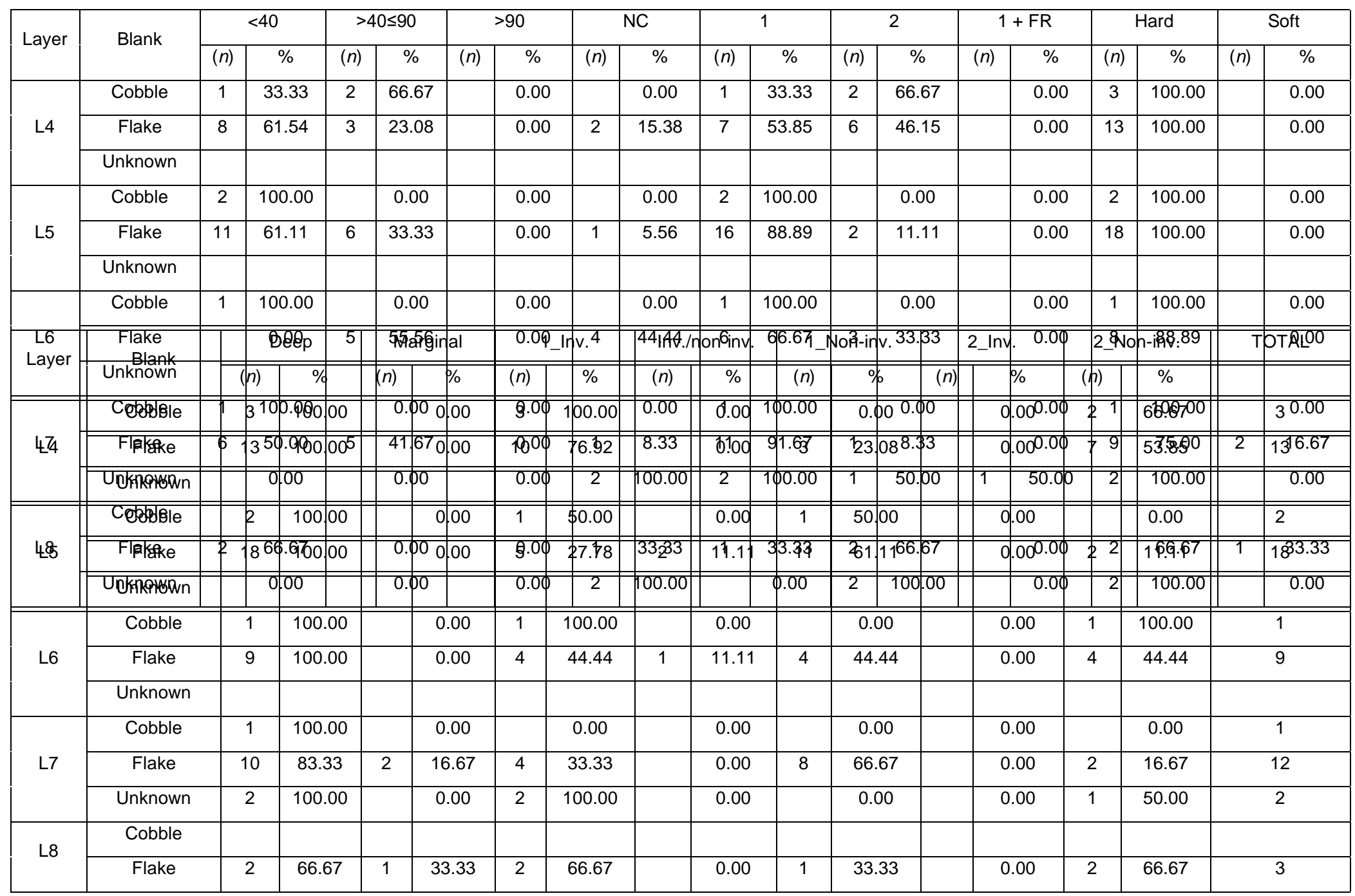




\begin{tabular}{|l|l|l|l|}
\hline & Unknown & 2 & 100.00 \\
\hline
\end{tabular}

\begin{tabular}{|l|c|c|c|}
\hline 0.00 & 2 & 100.00 \\
\hline
\end{tabular}

0.00

Abbreviations: Cortex remaining $(\leq 40,>40 \leq 90,>90)$; $\mathrm{NC}=$ no cortex; 1 = one removal series; 2 = two removal series; $1+\mathrm{FR}=$ one plus final retouch; Hard = hard percussion; Soft = soft percussion; Deep = deep effect on edges; Marginal = marginal effect on edges; 1 Inv. = first invasive removal series; Inv./non-inv. = combined; 1 Non-inv. = first non-invasive removal series; 2 Inv. = second invasive removal series; 2_Non-inv. = second non-invasive removal series; FR. Non-inv. = non-invasive final retouch. 


\section{SOM Table S7}

Technological features considered in an analysis of Butt of tools.

\begin{tabular}{|c|c|c|c|c|c|c|c|c|c|c|c|c|c|c|c|c|c|c|c|}
\hline \multirow{2}{*}{ Layer } & \multirow{2}{*}{ Blank } & \multicolumn{2}{|c|}{ GR_shap. } & \multicolumn{2}{|c|}{ SPC_shap. } & \multicolumn{2}{|c|}{ FR_shap. } & \multicolumn{2}{|c|}{$\leq 40$} & \multicolumn{2}{|c|}{$>40 \leq 90$} & \multicolumn{2}{|c|}{$>90$} & \multicolumn{2}{|c|}{$\mathrm{NC}$} & \multicolumn{2}{|c|}{1} & \multicolumn{2}{|r|}{2} \\
\hline & & (n) & $\%$ & $(n)$ & $\%$ & $(n)$ & $\%$ & (n) & $\%$ & $(n)$ & $\%$ & $(n)$ & $\%$ & (n) & $\%$ & $(n)$ & $\%$ & $(n)$ & $\%$ \\
\hline \multirow{3}{*}{ L4 } & Cobble & 2 & 66.67 & & 0.00 & 1 & 33.33 & & 0.00 & 1 & 33.33 & 2 & 66.67 & & 0.00 & 2 & 66.67 & & 0.00 \\
\hline & Flake & 12 & 92.31 & & 0.00 & 1 & 7.69 & 6 & 46.15 & 6 & 46.15 & 1 & 7.69 & & 0.00 & 12 & 92.31 & & 0.00 \\
\hline & Unknown & & & & & & & & & & & & & & & & & & \\
\hline \multirow{3}{*}{ L5 } & Cobble & 1 & 50.00 & & 0.00 & 1 & 50.00 & & 0.00 & 1 & 50.00 & 1 & 50.00 & & 0.00 & 1 & 50.00 & & 0.00 \\
\hline & Flake & 17 & 94.44 & & 0.00 & 1 & 5.56 & 6 & 33.33 & 11 & 61.11 & & 0.00 & 1 & 5.56 & 17 & 94.44 & & 0.00 \\
\hline & Unknown & & & & & & & & & & & & & & & & & & \\
\hline \multirow{3}{*}{ L6 } & Cobble & & 0.00 & & 0.00 & 1 & 100.00 & & 0.00 & & 0.00 & 1 & 100.00 & & 0.00 & 0 & 0.00 & & 0.00 \\
\hline & Flake & 8 & 88.89 & & 0.00 & 1 & 11.11 & & 0.00 & & 0.00 & 1 & 11.11 & & 0.00 & 6 & 66.67 & 2 & 22.22 \\
\hline & Unknown & & & & & & & & & & & & & & & & & & \\
\hline \multirow{3}{*}{ L7 } & Cobble & & 0.00 & 1 & 100.00 & & 0.00 & 1 & 100.00 & & 0.00 & & 0.00 & & 0.00 & 0 & 0.00 & 1 & 100.00 \\
\hline & Flake & 10 & 83.33 & 2 & 16.67 & & 0.00 & 2 & 16.67 & 9 & 75.00 & & 0.00 & 1 & 8.33 & 11 & 91.67 & & 0.00 \\
\hline & Unknown & 2 & 100.00 & & 0.00 & & 0.00 & & 0.00 & & 0.00 & & 0.00 & 2 & 100.00 & 1 & 50.00 & 1 & 50.00 \\
\hline \multirow{3}{*}{ L8 } & Cobble & & & & & & & & & & & & & & & & & & \\
\hline & Flake & 3 & 100.00 & & 0.00 & & 0.00 & 1 & 33.33 & 2 & 66.67 & & 0.00 & & 0.00 & 3 & 100.00 & & 0.00 \\
\hline & Unknown & 2 & 100.00 & & 0.00 & & 0.00 & 1 & 50.00 & & 0.00 & & 0.00 & 1 & 50.00 & 2 & 100.00 & & 0.00 \\
\hline
\end{tabular}

\begin{tabular}{|c|c|c|c|c|c|c|c|c|c|c|c|c|c|c|c|c|c|c|}
\hline \multirow{2}{*}{ Layer } & \multirow{2}{*}{ Blank } & \multicolumn{2}{|c|}{ Hard } & \multicolumn{2}{|c|}{ Soft } & \multicolumn{2}{|c|}{ Deep } & \multicolumn{2}{|c|}{ Marginal } & \multicolumn{2}{|c|}{ 1_Inv. } & \multicolumn{2}{|c|}{ Inv/non-inv. } & \multicolumn{2}{|c|}{ 1_Non-inv. } & \multicolumn{2}{|c|}{ 2_Non-inv. } & \multirow{2}{*}{ TOTAL } \\
\hline & & $(n)$ & $\%$ & (n) & $\%$ & (n) & $\%$ & (n) & $\%$ & (n) & $\%$ & (n) & $\%$ & (n) & $\%$ & (n) & $\%$ & \\
\hline \multirow{3}{*}{ L4 } & Cobble & 2 & 66.67 & & 0.00 & 2 & 66.67 & & 0.00 & 1 & 33.33 & & 0.00 & 1 & 33.33 & 1 & 33.33 & 3 \\
\hline & Flake & 12 & 92.31 & & 0.00 & 12 & 92.31 & & 0.00 & 5 & 38.46 & & 0.00 & 7 & 53.85 & 2 & 15.38 & 13 \\
\hline & Unknown & & & & & & & & & & & & & & & & & \\
\hline L5 & Cobble & 1 & $50, .00$ & & 0.00 & 1 & 50.00 & & 0.00 & & 0.00 & & 0.00 & 1 & 50.00 & & 0.00 & 2 \\
\hline
\end{tabular}




\begin{tabular}{|c|c|c|c|c|c|c|c|c|c|c|c|c|c|c|c|c|c|c|}
\hline & Flake & 17 & 94.44 & & 0.00 & 17 & 94.44 & & 0.00 & 5 & 27.78 & & 0.00 & 12 & 66.67 & & 0.00 & 18 \\
\hline & Unknown & & & & & & & & & & & & & & & & & \\
\hline \multirow{3}{*}{ L6 } & Cobble & & 0.00 & & 0.00 & & 0.00 & & 0.00 & & 0.00 & & 0.00 & & 0.00 & & 0.00 & 1 \\
\hline & Flake & 7 & 77.78 & & 0.00 & 8 & 88.89 & & 0.00 & 4 & 44.44 & 1 & 11.11 & 3 & 33.33 & 2 & 22.22 & 9 \\
\hline & Unknown & & & & & & & & & & & & & & & & & \\
\hline \multirow{3}{*}{ L7 } & Cobble & 1 & 100.00 & & 0.00 & 1 & 100.00 & & 0.00 & 1 & 100.00 & & 0.00 & & 0.00 & 1 & 100.00 & 1 \\
\hline & Flake & 9 & 75.00 & 1 & 8.33 & 9 & 75.00 & 2 & 16.67 & & 0.00 & & 0.00 & 11 & 91.67 & & 0.00 & 12 \\
\hline & Unknown & 2 & 100.00 & & 0.00 & 2 & 100.00 & & 0.00 & 2 & 100.00 & & 0.00 & & 0.00 & 1 & 50.00 & 2 \\
\hline \multirow{3}{*}{ L8 } & Cobble & & & & & & & & & & & & & & & & & \\
\hline & Flake & 2 & 66.67 & 1 & 33.33 & 2 & 66.67 & 1 & 33.33 & 1 & 33.33 & & 0.00 & 2 & 66.67 & & 0.00 & 3 \\
\hline & Unknown & 2 & 100.00 & & 0.00 & 2 & 100.00 & & 0.00 & 1 & 50.00 & & 0.00 & 1 & 50.00 & & 0.00 & 2 \\
\hline
\end{tabular}

Abbreviations: GR_shap. = general shaping; SPC_shap. = specific shaping; FR_shap. = final retouch shaping; Cortex remaining $(\leq 40,>40 \leq 90,>90)$; NC = no cortex; 1 = one removal series; 2 = two removal series; Hard = hard percussion; Soft = soft percussion; Deep = deep effect on edges; Marginal = marginal effect on edges; 1 Inv. = first invasive removal series; Inv/non-inv. = combined; $1 \_$Non-inv. = first non-invasive removal series; 2 _Non-inv. = second non-invasive removal series. 


\section{SOM Table S8}

Means, standard deviations (SD) and coefficients of variation (CV) for each measure and indices of large cutting tools from Menez-Dregan I by type of blank, layers and raw materials.

\begin{tabular}{|c|c|c|c|c|c|c|c|c|c|c|c|c|}
\hline & & $\begin{array}{l}\text { Length } \\
(\mathrm{L})\end{array}$ & $\begin{array}{l}\text { Width } \\
\text { (m) }\end{array}$ & $\begin{array}{c}\text { Thickness } \\
\text { (e) }\end{array}$ & $\begin{array}{c}\text { Width } \\
\text { at mid (n) }\end{array}$ & $\begin{array}{c}\text { Base } \\
\text { length (a) }\end{array}$ & $\begin{array}{l}\text { Distal length } \\
\quad(\mathrm{L}-\mathrm{a})\end{array}$ & $\begin{array}{l}\text { Distal width } \\
\text { (B1) }\end{array}$ & $\begin{array}{l}\text { Proximal } \\
\text { width (B2) }\end{array}$ & $\begin{array}{c}\text { Distal } \\
\text { thickness } \\
(\mathrm{T} 1)\end{array}$ & $\begin{array}{l}\text { Elongation } \\
\qquad(\mathrm{L} / \mathrm{m})\end{array}$ & $\begin{array}{l}\text { Refinement } \\
\qquad(\mathrm{m} / \mathrm{e})\end{array}$ \\
\hline \multirow{3}{*}{ Cobbles } & Mean & 134,91 & 80,08 & 45,14 & 72,36 & 66,29 & 68,62 & 71,34 & 40,62 & 45,55 & 1,69 & 1,85 \\
\hline & SD & 22,39 & 14,40 & 8,30 & 14,90 & 20,76 & 15,66 & 12,87 & 7,49 & 15,00 & 0,23 & 0,39 \\
\hline & CV & 0,17 & 0,18 & 0,18 & 0,21 & 0,31 & 0,23 & 0,18 & 0,18 & 0,33 & 0,13 & 0,21 \\
\hline \multirow{3}{*}{ Flakes } & Mean & 122,00 & 78,71 & 40,84 & 74,75 & 62,08 & 59,92 & 67,39 & 33,73 & 51,40 & 1,56 & 1,96 \\
\hline & SD & 22,75 & 13,68 & 8,42 & 14,27 & 21,89 & 17,51 & 12,21 & 7,50 & 15,86 & 0,21 & 0,39 \\
\hline & $\mathrm{CV}$ & 0,19 & 0,17 & 0,21 & 0,19 & 0,35 & 0,29 & 0,18 & 0,22 & 0,31 & 0,13 & 0,20 \\
\hline \multirow{3}{*}{ Unknown } & Mean & 120,04 & 70,94 & 48,13 & 64,21 & 47,08 & 72,96 & 63,59 & 36,32 & 46,88 & 1,69 & 1,51 \\
\hline & SD & 23,50 & 12,74 & 8,66 & 14,27 & 29,72 & 22,54 & 7,92 & 6,61 & 17,64 & 0,19 & 0,52 \\
\hline & $\mathrm{CV}$ & 0,20 & 0,18 & 0,18 & 0,22 & 0,63 & 0,31 & 0,12 & 0,18 & 0,38 & 0,11 & 0,35 \\
\hline \multirow{3}{*}{ Layer 4} & Mean & 124,35 & 75,57 & 41,81 & 70,58 & 60,92 & 63,43 & 66,24 & 35,21 & 47,05 & 1,65 & 1,82 \\
\hline & SD & 27,85 & 13,64 & 7,89 & 14,11 & 24,12 & 20,99 & 11,50 & 8,96 & 16,44 & 0,23 & 0,26 \\
\hline & CV & 0,22 & 0,18 & 0,19 & 0,20 & 0,40 & 0,33 & 0,17 & 0,25 & 0,35 & 0,14 & 0,14 \\
\hline \multirow{3}{*}{ Layer 5} & Mean & 118,62 & 77,77 & 38,92 & 72,61 & 52,37 & 66,25 & 68,01 & 33,08 & 48,33 & 1,55 & 2,03 \\
\hline & SD & 18,30 & 13,55 & 6,85 & 13,26 & 13,71 & 15,52 & 12,40 & 5,69 & 14,90 & 0,22 & 0,39 \\
\hline & CV & 0,15 & 0,17 & 0,18 & 0,18 & 0,26 & 0,23 & 0,18 & 0,17 & 0,31 & 0,14 & 0,19 \\
\hline \multirow{3}{*}{ Layer 6} & Mean & 129,27 & 84,21 & 45,23 & 81,87 & 71,86 & 57,41 & 70,54 & 36,16 & 51,84 & 1,55 & 1,90 \\
\hline & SD & 26,33 & 17,50 & 7,69 & 18,42 & 21,46 & 12,55 & 15,14 & 5,97 & 14,72 & 0,20 & 0,48 \\
\hline & CV & 0,20 & 0,21 & 0,17 & 0,23 & 0,30 & 0,22 & 0,21 & 0,17 & 0,28 & 0,13 & 0,25 \\
\hline \multirow{3}{*}{ Layer 7} & Mean & 126,32 & 80,23 & 42,95 & 75,17 & 68,64 & 57,68 & 68,63 & 35,50 & 54,87 & 1,58 & 1,95 \\
\hline & SD & 22,66 & 12,49 & 10,21 & 13,44 & 26,76 & 15,05 & 12,25 & 8,74 & 18,81 & 0,19 & 0,45 \\
\hline & CV & 0,18 & 0,16 & 0,24 & 0,18 & 0,39 & 0,26 & 0,18 & 0,25 & 0,34 & 0,12 & 0,23 \\
\hline \multirow{2}{*}{ Layer 8} & Mean & 117,01 & 72,65 & 42,13 & 69,35 & 59,28 & 57,72 & 61,02 & 33,13 & 54,45 & 1,62 & 1,79 \\
\hline & SD & 16,48 & 8,09 & 10,96 & 9,22 & 17,01 & 28,24 & 8,21 & 9,39 & 11,32 & 0,22 & 0,37 \\
\hline
\end{tabular}




\begin{tabular}{|c|c|c|c|c|c|c|c|c|c|c|c|c|}
\hline & CV & 0,14 & 0,11 & 0,26 & 0,13 & 0,29 & 0,49 & 0,13 & 0,28 & 0,21 & 0,13 & 0,21 \\
\hline Flint $^{\mathrm{a}}$ & - & 102,00 & 61,74 & 32,64 & 53,17 & 38,91 & 63,09 & 53,58 & 32,16 & 30,37 & 1,65 & 1,89 \\
\hline \multirow{3}{*}{ Quartz } & Mean & 108,00 & 74,41 & 46,47 & 71,04 & 58,45 & 49,54 & 63,19 & 36,02 & 57,26 & 1,45 & 1,60 \\
\hline & SD & 21,46 & 13,98 & 8,42 & 14,69 & 22,36 & 16,06 & 12,37 & 7,15 & 16,71 & 0,21 & 0,41 \\
\hline & CV & 0,20 & 0,19 & 0,18 & 0,21 & 0,38 & 0,32 & 0,20 & 0,20 & 0,29 & 0,15 & 0,25 \\
\hline \multirow{3}{*}{ Quartzite } & Mean & 126,18 & 79,29 & 43,63 & 76,07 & 68,05 & 58,13 & 67,43 & 34,91 & 55,89 & 1,59 & 1,87 \\
\hline & SD & 20,42 & 12,55 & 8,76 & 13,68 & 19,08 & 15,19 & 11,74 & 7,50 & 15,02 & 0,19 & 0,41 \\
\hline & $\mathrm{CV}$ & 0,16 & 0,16 & 0,20 & 0,18 & 0,28 & 0,26 & 0,17 & 0,21 & 0,27 & 0,12 & 0,22 \\
\hline \multirow{3}{*}{ Microgranite } & Mean & 113,23 & 73,39 & 40,40 & 69,92 & 54,06 & 59,17 & 61,79 & 32,77 & 45,11 & 1,57 & 1,86 \\
\hline & SD & 22,75 & 13,68 & 8,42 & 14,27 & 21,89 & 17,51 & 12,21 & 7,50 & 15,86 & 0,21 & 0,39 \\
\hline & $\mathrm{CV}$ & 0,20 & 0,19 & 0,21 & 0,20 & 0,41 & 0,30 & 0,20 & 0,23 & 0,35 & 0,13 & 0,21 \\
\hline \multirow{3}{*}{ Sandstone } & Mean & 130,67 & 82,04 & 42,07 & 76,67 & 65,97 & 64,71 & 71,85 & 35,63 & 52,81 & 1,60 & 2,00 \\
\hline & SD & 22,18 & 13,32 & 8,39 & 14,10 & 21,99 & 17,47 & 11,69 & 7,38 & 15,89 & 0,21 & 0,39 \\
\hline & CV & 0,17 & 0,16 & 0,20 & 0,18 & 0,33 & 0,27 & 0,16 & 0,21 & 0,30 & 0,13 & 0,19 \\
\hline
\end{tabular}

${ }^{\mathrm{a}}$ Only one flint tool. 


\section{SOM Table S9}

Total variance explained by the 10 principal components (PCs) in reference to the four graphs included in Figure 7.

\begin{tabular}{|c|c|c|c|c|c|c|c|c|c|c|c|}
\hline Tool part/PC & PC1 & PC2 & PC3 & PC4 & PC5 & PC6 & PC7 & PC8 & PC9 & PC10 & Total variance \\
\hline Tool (Fig. 7A) & 39.88 & 25.00 & 19.2 & 7.60 & 4.28 & 2.64 & 1.10 & 0.16 & 0.07 & 0.01 & 100.00 \\
\hline Tip (Fig. 7B) & 44.67 & 26.94 & 12.14 & 8.69 & 5.30 & 1.25 & 0.39 & 0.21 & 0.30 & 0.00 & 100.00 \\
\hline Middle (Fig. 7C) & 55.73 & 16.99 & 12.00 & 8.18 & 4.92 & 2.10 & 1.00 & 0.07 & 0.01 & 0.00 & 100.00 \\
\hline Butt (Fig. 7D) & 42.41 & 37.99 & 11.91 & 2.90 & 2.28 & 1.23 & 0.88 & 0.33 & 0.02 & 0.00 & 100.00 \\
\hline
\end{tabular}


SOM Table S10

Results of Wilcoxon Rank-sum tests between group means of handaxes and cleavers according to the type of blank.

\begin{tabular}{|c|c|c|c|c|}
\hline Type of blank & $n 1$ & $n 2$ & Rank-sum & $p$-value \\
\hline Cobble vs. flakes & 6 & 55 & 3324 & 0.02 \\
\hline Cobble vs. unknown blanks & 6 & 4 & 68 & $<0.01$ \\
\hline Flakes vs. unknown blanks & 55 & 4 & 2657 & $<0.01$ \\
\hline
\end{tabular}




\section{SOM Table S11}

Results of Wilcoxon Rank-sum test between group means of handaxes and cleavers depending on the layers.

\begin{tabular}{|c|c|c|c|c|}
\hline Layers & $n 1$ & $n 2$ & Rank-sum & $p$-value \\
\hline Layers 8/7 & 6 & 14 & 359 & 0.17 \\
\hline Layers 8/6 & 6 & 10 & 220 & 0.10 \\
\hline Layers 8/5 & 6 & 20 & 577 & 0.04 \\
\hline Layers 8/4 & 6 & 16 & 431 & 0.13 \\
\hline Layers 7/6 & 14 & 10 & 515 & 0.13 \\
\hline Layers 7/5 & 14 & 20 & 1040 & 0.10 \\
\hline Layers 7/4 & 14 & 16 & 814 & 0.13 \\
\hline Layers 6/5 & 10 & 20 & 851 & 0.34 \\
\hline Layers 6/4 & 10 & 16 & 607 & 0.13 \\
\hline Layers 5/4 & 20 & 16 & 1167 & 0.09 \\
\hline
\end{tabular}




\section{SOM References}

Gaillard, C. Ravon, A.-L., Monnier, J.-L., Hallégouët, B., Laforge, M., Hinguant, S., Marguerie, D., Van Vliet-Lanoë B., Marcoux N., Aoustin D., Le Bailly, M., Falguères, C., Bahain, J.-J., Mercier, N., Courty, M.-A., Chantreau, Y., Sellami, F., Bouju, V., 2017. Plouhinec (Finistère), Menez-Dregan I, Des Prénéandertaliens aux Néandertaliens, les premières occupations paléolithiques. Rapport triennal de fouille programmée. CNRS-UMR 6566 CReAAH, CNRS-UMR 7194 HNHP, Université de Rennes 1, Ministère de la Culture et de la Communication, MNHN, Conseil Général du Finistère, Mairie de Plouhinec.

Laforge, M., 2012. Le cadre chronostratigraphique des peuplement pléistocènes de l'Ouest de la France. Eustatisme, changements climatiques et occupations humaines. Ph.D. Dissertation, Université de Rennes 1.

Laforge, M., Monnier, J.-L., 2011. Contribution à la chronostratigraphie du gisement Paléolithique inférieur de Menez-Dregan 1 (Plouhinec, Finistère, France). Corrélations avec les dépôts pléistocènes de la falaise de Gwendrez. Quaternaire 22, n², 91-104.

Monnier, J.-L., Hallégouët, B., Hinguant, S., Molines, N., 1996. Rapport de fin d'opération pluriannuelle sur la fouille du gisement paléolithique inférieur de Menez-Dregan I (Plouhinec, Finistère). DRAC Bretagne, Service Régional de l'Archéologie de Bretagne, UMR 153 du CNRS, t. 1, Rennes.

Monnier, J.-L., Ravon, A.-L., Hinguant, S., Hallégouët, B., Gaillard, C., Laforge, M., 2016a. Menez-Dregan (Plouhinec, Finistère, France): un site d'habitat du Paléolithique inférieur en grotte marine. Stratigraphie, structures de combustion, industries riches en galets aménagés. L'Anthropologie 120, 237-262.

Monnier, J.-L., Lefort, J.-P., Cliquet, D., Hinguant, S., Huet, B., Pigeaud, R., Ravon, A.-L., 2016b. Des Mammouths et des Hommes en Armorique, Occupations humaines et variations de l'environnement au Pléistocène dans l'Ouest de la France. Bull. Musée Anthropol. Préhist. Monaco 6, 91-121.

Ravon, A.-L., 2017a. Originalité et développement du Paléolithique inférieur à l'extrémité occidentale de l'Eurasie : le « Colombanien » de Menez-Dregan (Plouhinec, Finistère, Bretagne). Ph.D. Dissertation, Université Rennes 1.

Ravon, A.-L., 2017b. 30 ans de fouilles à Menez-Dregan I (Plouhinec, Finistère). Bull. A.M.A.R.A.I., n`30, 35-52.

Ravon, A.-L., 2019. Early human occupations at the Westernmost tip of Eurasia: The lithic industries from Menez-Dregan I (Plouhinec, Finistère, France). C.R. Palevol 18, 663-684.

Ravon, A.-L., Laforge, M., 2019. Du Paléolithique inférieur au Paléolithique moyen ancien à l'ouest de la péninsule armoricaine : une revue des occupations saaliennes de Bretagne. In: Montoya, C., Fagnart, J.P., Locht, J.-L. (Eds.), Préhistoire de l'Europe du Nord-Ouest: Mobilités, Climats et Entités Culturelles, Actes du XXVIIle Congrès Préhistorique de France - Amiens, 30 mai-4 juin 2016, vol. 1, 201-214.

Ravon, A.-L., Monnier, J.-L., 2013. La transition Paléolithique inférieur-moyen dans l'Ouest armoricain : l'exemple de la couche 4 du site de Menez-Dregan I (Plouhinec, Finistère). Bull. Soc. Préhist. Française 110, 7-23.

Ravon, A.-L., Monnier, J.-L., Laforge, M., 2016a. Menez-Dregan, layer 4: A transitional layer between the Lower and Middle Palaeolithic in Brittany. Quat. Int. 409, 92-103.

Ravon, A.-L., Gaillard, C., Monnier, J.-L., 2016b. Menez-Dregan (Plouhinec, Far Western Europe): The lithic industry from layer 7 and its Acheulian components. Quat. Int. 411, 132143. 
Ravon, A.-L., García-Medrano, P., Bernard, Y., Guégan, S., Laforge, M., Le Goff, E., Sylvain, A., Gaillard, C., Hinguant, S., Monnier, J.-L., 2020. Plouhinec (Finistère), Menez-Dregan I, Des Prénéandertaliens aux Néandertaliens, les premières occupations paléolithiques, rapport de fouille programmée. CNRS-UMR $6566 \mathrm{CReAAH}$, Université de Rennes 1, Ministère de la Culture et de la Communication, Mairie de Plouhinec. 